\title{
Seven Reversible Redox Processes in a Self-Assembled Cobalt Pentanuclear Bis(triple-stranded helicate): Structural, Spectroscopic, and Magnetic Characterizations in the $\mathrm{Co}^{\prime} \mathrm{Co}_{4}{ }_{4}, \mathrm{Co}^{\prime \prime}{ }_{5}$, and $\mathrm{CO}_{3}{ }_{3} \mathrm{Co}{ }^{\prime \prime \prime}{ }_{2}$ Redox States
}

Eric Gouré, Bertrand Gerey, Florian Molton, Jacques Pécaut, Rodolphe Clérac, Fabrice Thomas, Jérôme Fortage, and Marie-Noëlle Collomb*

\begin{abstract}
We report on the synthesis and structural characterization of the cobalt pentanuclear helicate complex from the rigid tetradentate bis(2-pyridyl)-3,5-pyrazolate ligand $\mathrm{bpp}^{-}$, namely, $\left[\left\{\mathrm{Co}^{\mathrm{II}}(\mu \text {-bpp })_{3}\right\}_{2} \mathrm{Co}_{3}{ }_{3}\left(\mu_{3}-\mathrm{OH}\right)\right]^{3+}\left(1^{3+}\right)$, in which a trinuclear $\left\{\mathrm{Co}_{3}{ }_{3}\left(\mu_{3}-\mathrm{OH}\right)\right\}$ core is wrapped by two $\left\{\mathrm{Co}^{\mathrm{II}}(\mu \text {-bpp })_{3}\right\}$ units. The cyclic voltammogram of $\mathbf{1}^{3+}$ in $\mathrm{CH}_{3} \mathrm{CN}$ revealed seven successive reversible one-electron waves, in the 0 and $-3.0 \mathrm{~V}$ potential range, highlighting the remarkable stability of such architecture in several redox states. Two mixed-valent states of this complex, the twoelectron-oxidized $\mathrm{Co}_{3}{ }_{3} \mathrm{Co}^{\mathrm{III}}{ }_{2}\left(1^{5+}\right)$ and the one-electron-reduced species $\mathrm{Co}^{\mathrm{I}} \mathrm{Co}_{4}{ }_{4}\left(1^{2+}\right)$, were generated by bulk electrolyses and successfully characterized by single-crystal X-ray diffraction among the eight redox levels between $\mathrm{Co}_{5}{ }_{5}$ and $\mathrm{Co}_{3}{ }_{3} \mathrm{Co}^{\mathrm{III}}{ }_{2}$ that can be

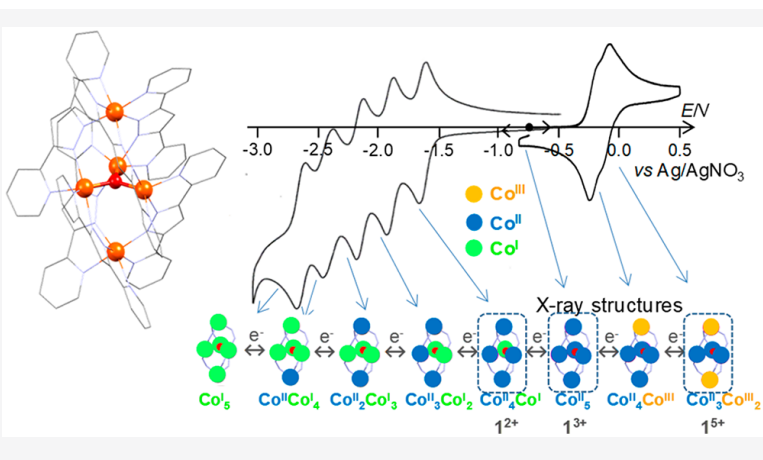
accessed under electrochemical conditions. Because of the crystallographic characterization of $\mathbf{1}^{5+}$ and $\mathbf{1}^{2+}$, the five reduction processes located at $E_{1 / 2}$ values of $-1.63\left(1^{3+/ 2+}\right),-1.88\left(1^{2+/+}\right),-2.14\left(\mathbf{1}^{+/ 0}\right),-2.40\left(1^{0 /-}\right)$, and $-2.60 \mathrm{~V}\left(\mathbf{1}^{-/ 2-}\right)$ versus $\mathrm{Ag} /$ $\mathrm{AgNO}_{3}$ were unambiguously assigned to the successive reduction of each of the five $\mathrm{Co}$ (II) ions to $\mathrm{Co}(\mathrm{I})$, starting with the three ions located in the central core followed by the two apical ions. The two other redox events at $E_{1 / 2}$ values of $-0.21\left(1^{4+/ 3+}\right)$ and $-0.11 \mathrm{~V}\left(1^{5+/ 4+}\right)$ are assigned to the successive oxidation of the apical Co(II) ions to Co(III). The Co(I) complexes are rare, and the stabilization of a Co(I) within a trinuclear $\mu$-hydroxo core in the reduced species, $\mathbf{1}^{2+}, \mathbf{1}^{+}, \mathbf{1}^{\mathbf{0}}, \mathbf{1}^{-}$, and $\mathbf{1}^{2-}$, is probably the result of the particular structure of this complex in the presence of the two apical sites that maintain the trinuclear core through the six bridging $\mathrm{bpp}^{-}$ligands. The spectroscopic characteristics of $\mathbf{1}^{2+}, \mathbf{1}^{3+}$, and $\mathbf{1}^{5+}$ (ultraviolet-visible and X-band electron paramagnetic resonance) are also described as well as their magnetic properties in the solid state.
\end{abstract}

\section{INTRODUCTION}

The self-assembly of polynuclear coordination complexes has attracted considerable attention over the past few decades. ${ }^{1-3}$ It is now possible to direct synthesis toward structures with well-defined nuclearity and geometry by altering the ligand properties (rigidity, number and orientation of coordination sites, and nature of donor atoms) and the nature of the metal ions. ${ }^{4}$ Among bridging ligands, heterocycles with two adjacent nitrogen donors such as pyrazolates, pyridazines, triazoles, and derivatives have been extensively used to design polynuclear complexes. Beyond their ability to maintain two metal ions in the proximity of each other, they indeed allow an electronic communication between these centers providing peculiar electronic properties and reactivities. ${ }^{5-8}$ More particularly, the rigid tetradentate 3,5-bis(pyridyn-2-yl)-pyrazole (Hbpp) ligand ${ }^{9}$ can form, by self-assembly with various first-row transition metal ions at high temperatures, remarkable bis(triple) helicate pentanuclear architectures of the type $\left[\left\{\mathrm{M}(\mu \text {-bpp })_{3}\right\}_{2} \mathrm{M}_{3}\left(\mu_{3}-\mathrm{X}\right)\right]^{n+}(\mathrm{M}=\mathrm{Mn}$ or Fe with $\mathrm{X}=\mathrm{O}$, and $\mathrm{M}=\mathrm{Ni}$ or $\mathrm{Zn}$ with $\mathrm{X}=\mathrm{OH}) .{ }^{10-13}$ The five metal ions are arranged in a trigonal bipyramidal topology with two axial $\left\{\mathrm{M}^{\mathrm{II}}(\mu \text {-bpp })_{3}\right\}$ units connecting a central $\mu_{3}$-oxo or hydroxo trinuclear core $\left\{\mathrm{M}_{3}\left(\mu_{3}-\mathrm{X}\right)\right\}$ through the bridging bpp ${ }^{-}$ligands. Interesting structure-specific physicochemical properties have been observed for this family of complexes, such as spin frustration for the copper complex, ${ }^{11}$ while for the iron derivative, it has been shown that the spin states of the two 

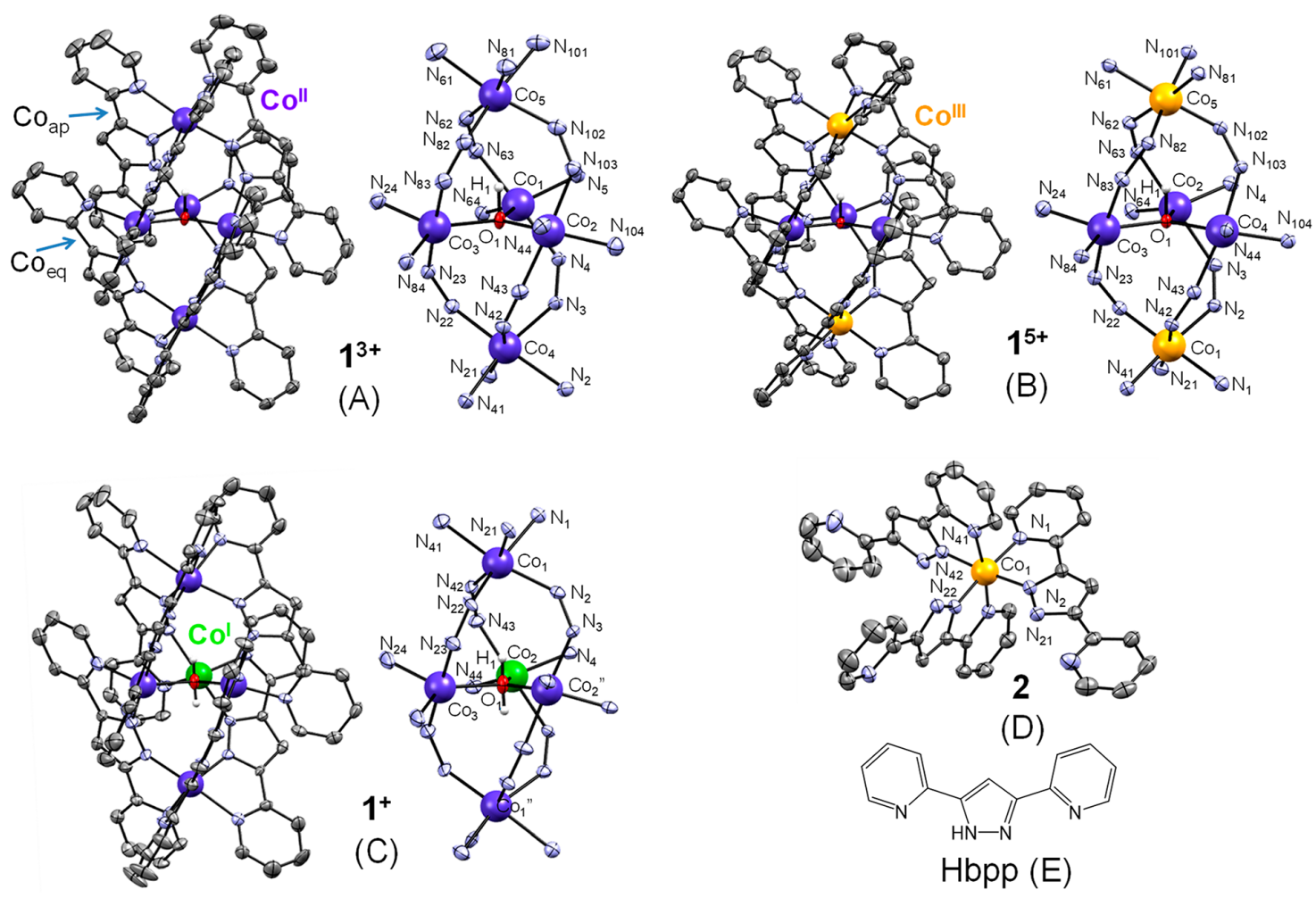

(D)<smiles>c1ccc(-c2cc(-c3ccccn3)[nH]n2)nc1</smiles>

$\operatorname{Hbpp}(\mathrm{E})$

Figure 1. ORTEP representations with $50 \%$ probability thermal ellipsoids of the molecular structures of $(\mathrm{A})$ the $\left[\left\{\mathrm{Co}^{\mathrm{II}}(\mu \text {-bpp })_{3}\right\}_{2} \mathrm{Co}_{3}{ }_{3}\left(\mu_{3}-\mathrm{OH}\right)\right]^{3+}$ cation $\left(1^{3+}\right),(\mathrm{B})$ the $\left[\left\{\mathrm{Co}^{\mathrm{III}}(\mu \text {-bpp })_{3}\right\}_{2} \mathrm{Co}_{3}{ }_{3}\left(\mu_{3}-\mathrm{OH}\right)\right]^{\mathrm{St}}$ cation $\left(1^{5+}\right),(\mathrm{C})$ the $\left[\left\{\mathrm{Co}^{\mathrm{II}}(\mu \text {-bpp })_{3}\right\}_{2} \mathrm{Co}^{\mathrm{I}} \mathrm{Co}_{2}{ }_{2}\left(\mu_{3}-\mathrm{OH}\right)\right]^{2+}$ cation $\left(\mathbf{1}^{2+}\right)$, (D) the neutral $\left[\mathrm{Co}{ }^{\mathrm{III}}(\mathrm{bpp})_{3}\right]$ complex $(2)$, and $(\mathrm{E})$ the Hbpp ligand. The hydrogen atoms have been omitted for the sake of clarity. On the right side of panels A$\mathrm{C}$, the corresponding metallic cores including the first coordination spheres of the metal ions are shown.

apical $\mathrm{Fe}(\mathrm{II})$ ions can be tuned through the choice of the counteranions. ${ }^{14-16}$ For the manganese and iron derivatives, we also demonstrated that the electronically coupled five metal atoms give to the architecture a multiredox behavior with the detection of five successive reversible metal-centered $\mathrm{M}^{\mathrm{II} / \mathrm{III}}$ processes. ${ }^{12,17,18}$ The group of Masaoka also recently reported that the iron complex can serve as an active catalyst for the electrocatalytic water oxidation because of its ability to accumulate four oxidative equivalents, the four-electron oxidized species, $\mathrm{Fe}^{\mathrm{III}}{ }_{5}$, being reactive with $\mathrm{H}_{2} \mathrm{O}$ to generate $\mathrm{O}_{2} \cdot{ }^{19-21}$ From the bpp ${ }^{-}$ligand, a few homo- and heterobimetallic di- and trinuclear cobalt complexes have also been isolated, presenting, for some of them, interesting catalytic properties for water oxidation and oxygen or proton reduction. ${ }^{7,22-25}$ Because of its electronic configuration that gives access to the three potentially stable oxidation states, $+\mathrm{I}$, + II, and +III, cobalt could be an intriguing metal ion in the $\left.\left\{\mathrm{M}(\mu \text {-bpp })_{3}\right\}_{2} \mathrm{M}_{3}\left(\mu_{3}-\mathrm{X}\right)\right\}^{n+}$ architecture. Along this line, we herein report on the synthesis and $\mathrm{X}$-ray characterization of the $\left[\left\{\mathrm{Co}^{\mathrm{II}}(\mu \text {-bpp })_{3}\right\}_{2} \mathrm{Co}_{3}{ }_{3}\left(\mu_{3}-\mathrm{OH}\right)\right]^{3+}\left(1^{3+}\right)$ complex and on its redox properties in $\mathrm{CH}_{3} \mathrm{CN}$. This complex presents a remarkable stability in several redox states with up to seven reversible waves detected by cyclic voltammetry assigned to $\mathrm{Co}^{\mathrm{II} / \mathrm{I}}$ and $\mathrm{Co}^{\mathrm{III} / \mathrm{II}}$ processes. This excellent stability in several redox states allowed us to generate quantitatively by preparative electrolyses and crystallize two other redox states, the two-electron-oxidized form, $\left[\left\{\mathrm{Co}^{\mathrm{III}}(\mu \text {-bpp })_{3}\right\}_{2} \mathrm{Co}_{3}^{\mathrm{II}}\left(\mu_{3}-\right.\right.$ $\mathrm{OH})]^{5+}\left(1^{5+}\right)$, and the one-electron-reduced form, $\left[\left\{\mathrm{Co}^{\mathrm{II}}(\mu-\right.\right.$ $\left.\left.\mathrm{bpp})_{3}\right\}_{2} \mathrm{Co}^{\mathrm{I}} \mathrm{Co}_{2}{ }_{2}\left(\mu_{3}-\mathrm{OH}\right)\right]^{2+}\left(\mathbf{1}^{2+}\right)$. During the preparation of this Article, Masaoka and co-workers ${ }^{26}$ published the isolation and X-ray structural characterization of the $\mathbf{1}^{3+}$ complex. In this recent article, they also showed that this complex, upon reduction, can act as a catalyst for the reduction of $\mathrm{CO}_{2}$ to $\mathrm{CO}$ under photoirradiation in the presence of a photosensitizer and a sacrificial electron donor. Only five reversible waves were detected by cyclic voltammetry, and this complex was not further characterized by spectroscopy, magnetism, or electrolysis. In this Article, in addition to the X-ray structural characterization of the $\mathbf{1}^{2+}, \mathbf{1}^{3+}$, and $\mathbf{1}^{5+}$ complexes, we also describe their spectroscopic characteristics by ultravioletvisible (UV-vis) and X-band electron paramagnetic resonance (EPR) spectroscopies as well as their magnetic properties.

\section{RESULTS AND DISCUSSION}

Synthesis and Crystal Structures of the Complexes. $1^{3+}$ was synthesized in $90 \%$ yield by thermal treatment at 170 ${ }^{\circ} \mathrm{C}$ for 3 days of an acetonitrile mixture of $\mathrm{Hbpp}$ and $\mathrm{Co}\left(\mathrm{BF}_{4}\right)_{2} \cdot 4 \mathrm{H}_{2} \mathrm{O}(6: 5$ molar ratio $)$ in the presence of an excess of the $\mathrm{Et}_{3} \mathrm{~N}$ base, under aerobic conditions. This procedure is similar to the one we previously employed to isolate the analogous manganese and iron derivatives, $\left[\left\{\mathrm{M}^{\mathrm{II}}(\mu\right.\right.$ bpp $\left.\left.)_{3}\right\}_{2} \mathrm{M}^{\mathrm{II}}{ }_{2} \mathrm{M}^{\mathrm{III}}\left(\mu_{3}-\mathrm{O}\right)\right]^{3+}$ complexes $(\mathrm{M}=\mathrm{Mn}$ or $\mathrm{Fe}){ }^{12,17}$ The group of Masaoka ${ }^{26}$ employed a different procedure that consists of reacting cobalt acetate with the ligand in methanol at $40{ }^{\circ} \mathrm{C}$ in the presence of $\mathrm{NaOH}$ and then adding $\mathrm{NaBF}_{4}$ to induce the precipitation of the complex. In addition to $1^{3+}$, we also succeeded in generating and isolating the two-electronoxidized form of the complex and its one-electron-reduced 
Table 1. Comparison of Selected Co Ligand Bond Lengths (angstroms) and Co- $\mu(\mathrm{OH})-\mathrm{Co}$ Angles (degrees) for $\left[\left\{\mathrm{Co}^{\mathrm{II}}(\mu-\right.\right.$ bpp $\left.\left.)_{3}\right\}_{2} \mathrm{Co}^{\mathrm{I}} \mathrm{Co}_{2}^{\mathrm{II}}\left(\mu_{3}-\mathrm{OH}\right)\right]\left(\mathrm{ClO}_{4}\right)_{2} \cdot 2 \mathrm{CH}_{3} \mathrm{CN}\left(1^{2+}\right),\left[\left\{\mathrm{Co}^{\mathrm{II}}(\mu-\mathrm{bpp})_{3}\right\}_{2} \mathrm{Co}_{3}^{\mathrm{II}}\left(\mu_{3}-\mathrm{OH}\right)\right]\left(\mathrm{BF}_{4}\right)_{3} \cdot 3.75 \mathrm{CH}_{3} \mathrm{CN} \cdot 0.33 \mathrm{H}_{2} \mathrm{O}\left(1^{3+}\right)$, $\left[\left\{\mathrm{Co}^{\mathrm{III}}(\mu \text {-bpp })_{3}\right\}_{2} \mathrm{Co}_{3}{ }_{3}\left(\mu_{3}-\mathrm{OH}\right)\right]\left(\mathrm{ClO}_{4}\right)_{5} \cdot 6 \mathrm{CH}_{3} \mathrm{CN}\left(1^{5+}\right)$, and $\left[\mathrm{Co}^{\mathrm{III}}(\mathrm{bpp})_{3}\right] \cdot 0.5 \mathrm{CH}_{3} \mathrm{CN} \cdot\left(\mathrm{CH}_{3}\right)_{2} \mathrm{CO} \cdot 0.5\left(\left(\mathrm{CH}_{3}\right)_{2} \mathrm{CH}\right)_{2} \mathrm{O}(2)$ (apical, ap; equatorial, eq)

\begin{tabular}{|c|c|c|c|c|c|c|c|}
\hline \multicolumn{2}{|c|}{$1^{2+}$} & \multicolumn{2}{|c|}{$1^{3+}$} & \multicolumn{2}{|c|}{$1^{5+}$} & \multicolumn{2}{|c|}{2} \\
\hline \multicolumn{8}{|c|}{ Average of $\mathrm{Co}_{\mathrm{ap}}-\mathrm{N}$ Distances in the Apical Position } \\
\hline \multirow[t]{2}{*}{$\mathrm{Co}(1)$} & $2.15(5)$ & $\mathrm{Co}(4)$ & $2.15(5)$ & $\mathrm{Co}(1)$ & $1.94(3)$ & $\mathrm{Co}(1)$ & $1.92(3)$ \\
\hline & & $\mathrm{Co}(5)$ & $2.15(5)$ & $\mathrm{Co}(5)$ & $1.95(3)$ & & \\
\hline \multicolumn{8}{|c|}{ Average of $\mathrm{Co}_{\mathrm{eq}}-\mathrm{N}, \mathrm{O}$ Distances in the Equatorial Position (core) } \\
\hline $\mathrm{Co}(2)$ & $2.07(2)$ & $\mathrm{Co}(1)$ & $2.06(2)$ & $\mathrm{Co}(2)$ & $2.060(6)$ & & \\
\hline \multirow[t]{2}{*}{$\mathrm{Co}(3)$} & $2.04(4)$ & $\mathrm{Co}(2)$ & $2.06(1)$ & $\mathrm{Co}(3)$ & $2.06(1)$ & & \\
\hline & & $\mathrm{Co}(3)$ & $2.06(2)$ & $\mathrm{Co}(4)$ & $2.054(9)$ & & \\
\hline \multicolumn{8}{|c|}{$\mathrm{Co}_{\mathrm{eq}}-\mathrm{O}$ Distances } \\
\hline $\mathrm{Co}(2)$ & $1.958(3)$ & $\mathrm{Co}(1)$ & $2.0399(14)$ & $\mathrm{Co}(2)$ & $2.039(5)$ & & \\
\hline \multirow[t]{2}{*}{$\mathrm{Co}(3)$} & $2.056(6)$ & $\mathrm{Co}(2)$ & $2.0277(14)$ & $\mathrm{Co}(3)$ & $2.027(5)$ & & \\
\hline & & $\mathrm{Co}(3)$ & $2.0224(14)$ & $\mathrm{Co}(4)$ & $2.051(5)$ & & \\
\hline \multicolumn{8}{|c|}{$\mathrm{Co}_{\mathrm{eq}}-\mathrm{O}-\mathrm{Co}_{\mathrm{eq}}$ Angles } \\
\hline $\mathrm{Co}(2), \mathrm{Co}(3)$ & $116.87(17)$ & $\mathrm{Co}(2), \mathrm{Co}(1)$ & $118.11(7)$ & $\mathrm{Co}(2), \mathrm{Co}(3)$ & $120.6(2)$ & & \\
\hline $\mathrm{Co}\left(2^{\prime \prime}\right), \mathrm{Co}(3)$ & $116.86(17)$ & $\mathrm{Co}(3), \mathrm{Co}(1)$ & $120.35(7)$ & $\mathrm{Co}(2), \mathrm{Co}(4)$ & $118.1(2)$ & & \\
\hline $\mathrm{Co}\left(2^{\prime \prime}\right), \mathrm{Co}(2)$ & $126.3(3)$ & $\mathrm{Co}(3), \mathrm{Co}(2)$ & $121.50(7)$ & $\mathrm{Co}(3), \mathrm{Co}(4)$ & $121.1(2)$ & & \\
\hline
\end{tabular}

Table 2. Comparison of Co $\cdots$ Co Bond Lengths (angstroms) for $\left[\left\{\mathrm{Co}^{\mathrm{II}}(\mu \text {-bpp })_{3}\right\}_{2} \mathrm{Co}^{\mathrm{I}} \mathrm{Co}_{2}^{\mathrm{II}}{ }_{2}\left(\mu_{3}-\mathrm{OH}\right)\right]\left(\mathrm{ClO}_{4}\right)_{2} \cdot 2 \mathrm{CH}_{3} \mathrm{CN}\left(1^{2+}\right)$, $\left[\left\{\mathrm{Co}^{\mathrm{II}}(\mu \text {-bpp })_{3}\right\}_{2} \mathrm{Co}_{3}{ }_{3}\left(\mu_{3}-\mathrm{OH}\right)\right]\left(\mathrm{BF}_{4}\right)_{3} \cdot 3.75 \mathrm{CH}_{3} \mathrm{CN} \cdot 0.33 \mathrm{H}_{2} \mathrm{O}\left(1^{3+}\right)$, and $\left[\left\{\mathrm{Co}^{\mathrm{III}}(\mu \text {-bpp })_{3}\right\}_{2} \mathrm{Co}_{3}{ }_{3}\left(\mu_{3}-\mathrm{OH}\right)\right]\left(\mathrm{ClO}_{4}\right)_{5} \cdot 6 \mathrm{CH}_{3} \mathrm{CN}$ $\left(1^{5+}\right)$ (apical, ap; equatorial, eq)

\begin{tabular}{|c|c|c|c|c|c|c|}
\hline \multirow[b]{2}{*}{$\mathrm{Co}_{\mathrm{ap}} \cdots \mathrm{Co}_{\mathrm{eq}}$} & \multicolumn{2}{|c|}{$1^{2+}$} & \multicolumn{2}{|c|}{$1^{3+}$} & \multicolumn{2}{|c|}{$1^{5+}$} \\
\hline & $\mathrm{Co}(1) \cdots \mathrm{Co}(2)$ & $4.3060(4)$ & $\mathrm{Co}(4) \cdots \mathrm{Co}(1)$ & $4.3611(2)$ & $\mathrm{Co}(1) \cdots \mathrm{Co}(2)$ & $4.26719(13)$ \\
\hline & $\operatorname{Co}(1) \cdots \operatorname{Co}\left(2^{\prime \prime}\right)$ & $4.4199(4)$ & $\mathrm{Co}(4) \cdots \mathrm{Co}(2)$ & $4.3322(3)$ & $\mathrm{Co}(1) \cdots \mathrm{Co}(3)$ & $4.2879(2)$ \\
\hline & $\mathrm{Co}(1) \cdots \mathrm{Co}(3)$ & $4.2832(3)$ & $\mathrm{Co}(4) \cdots \mathrm{Co}(3)$ & $4.3760(3)$ & $\operatorname{Co}(1) \cdots \operatorname{Co}(4)$ & $4.2537(2)$ \\
\hline & & & $\mathrm{Co}(5) \cdots \mathrm{Co}(1)$ & $4.3342(3)$ & $\mathrm{Co}(5) \cdots \operatorname{Co}(2)$ & $4.2965(3)$ \\
\hline & & & $\mathrm{Co}(5) \cdots \mathrm{Co}(2)$ & $4.3650(3)$ & $\mathrm{Co}(5) \cdots \mathrm{Co}(3)$ & $4.3055(2)$ \\
\hline & & & $\mathrm{Co}(5) \cdots \mathrm{Co}(3)$ & $4.3295(2)$ & $\mathrm{Co}(5) \cdots \mathrm{Co}(4)$ & $4.30583(8)$ \\
\hline \multirow{3}{*}{$\mathrm{Co}_{\mathrm{eq}} \cdots \mathrm{Co}_{\mathrm{eq}}$} & $\mathrm{Co}(2) \cdots \mathrm{Co}(3)$ & $3.4208(2)$ & $\mathrm{Co}(1) \cdots \mathrm{Co}(2)$ & $3.4887(2)$ & $\mathrm{Co}(2) \cdots \mathrm{Co}(3)$ & $3.5307(6)$ \\
\hline & $\mathrm{Co}\left(2^{\prime \prime}\right) \cdots \mathrm{Co}(3)$ & $3.4208(2)$ & $\mathrm{Co}(2) \cdots \mathrm{Co}(3)$ & $3.5337(2)$ & $\mathrm{Co}(3) \cdots \mathrm{Co}(4)$ & $3.55085(15)$ \\
\hline & $\mathrm{Co}(2) \cdots \operatorname{Co}\left(2^{\prime \prime}\right)$ & $3.4942(2)$ & $\mathrm{Co}(1) \cdots \operatorname{Co}(3)$ & $3.52419(18)$ & $\mathrm{Co}(4) \cdots \mathrm{Co}(2)$ & $3.50779(17)$ \\
\hline $\mathrm{Co}_{\mathrm{ap}} \cdots \mathrm{Co}_{\mathrm{ap}}$ & $\operatorname{Co}(1) \cdots \operatorname{Co}\left(1^{\prime \prime}\right)$ & $7.7052(6)$ & $\mathrm{Co}(4) \cdots \mathrm{Co}(5)$ & $7.6942(5)$ & $\mathrm{Co}(1) \cdots \operatorname{Co}(5)$ & $7.5412(3)$ \\
\hline
\end{tabular}

form, $\mathbf{1}^{5+}$ and $\mathbf{1}^{2+}$, respectively, from preparative electrolyses (see below and Experimental Section). Single crystals of $\mathbf{1}\left(\mathrm{BF}_{4}\right)_{3} \cdot 3.75 \mathrm{CH}_{3} \mathrm{CN} \cdot 0.33 \mathrm{H}_{2} \mathrm{O}, \quad \mathbf{1}\left(\mathrm{ClO}_{4}\right)_{5} \cdot 6 \mathrm{CH}_{3} \mathrm{CN}$, and $\mathbf{1}\left(\mathrm{ClO}_{4}\right)_{2} \cdot 2 \mathrm{CH}_{3} \mathrm{CN}$ suitable for $\mathrm{X}$-ray crystallography were obtained by diffusion of diisopropyl ether into acetonitrile solutions of the respective complex (Figure 1A-C, Figure S1, and Tables S1-S4). The structure of $1\left(\mathrm{BF}_{4}\right)_{3} \cdot 3.75 \mathrm{CH}_{3} \mathrm{CN}$. $0.33 \mathrm{H}_{2} \mathrm{O}$ is very similar to that obtained by the group of Masaoka, which crystallizes as $\mathbf{1}\left(\mathrm{BF}_{4}\right)_{3} \cdot \mathrm{CH}_{3} \mathrm{CN} \cdot \mathrm{H}_{2} \mathrm{O} \cdot 2$ $\left(\left(\mathrm{C}_{2} \mathrm{H}_{5}\right)_{2} \mathrm{O}\right)$ in the same monoclinic $P 2_{1} / n$ space group. $\mathbf{1}\left(\mathrm{ClO}_{4}\right)_{5} \cdot 6 \mathrm{CH}_{3} \mathrm{CN}$ and $\mathbf{1}\left(\mathrm{ClO}_{4}\right)_{2} \cdot 2 \mathrm{CH}_{3} \mathrm{CN}$ crystallize in the monoclinic $\mathrm{Cc}$ and $\mathrm{C} 2 / \mathrm{c}$ space groups, respectively. On the basis of the charge of the cations, together with the presence of a $\mu_{3}$-hydroxo bridge, the Co oxidation states for $\mathbf{1}^{2+}, \mathbf{1}^{3+}$, and $1^{5+}$ were assigned as follows: $\mathrm{Co}^{\mathrm{I}} \mathrm{Co}_{4}{ }_{4}, \mathrm{Co}_{5}{ }_{5}$, and $\mathrm{Co}_{3}{ }_{3} \mathrm{Co}^{\mathrm{III}}{ }_{2}$, respectively. This description of the redox isomers is fully confirmed by the single-crystal $\mathrm{X}$-ray structure analysis (see below).

Similarly to the analogous $\left[\left\{\mathrm{M}^{\mathrm{II}}(\mu \text {-bpp })_{3}\right\}_{2} \mathrm{M}_{3}^{\mathrm{II}}\left(\mu_{3}-\mathrm{OH}\right)\right]^{3+}$ and $\left[\left\{\mathrm{M}^{\mathrm{II}}(\mu \text {-bpp })_{3}\right\}_{2} \mathrm{M}_{3}^{\mathrm{II}}\left(\mu_{3}-\mathrm{O}\right)\right]^{4+}$ complexes, ${ }^{10-14}$ each cation, $\mathbf{1}^{2+}, \mathbf{1}^{3+}$, or $\mathbf{1}^{5+}$, features a bis(triple-stranded helicate) configuration, with a pair of enantiomers present in each crystal. The coordination environment of the three Co ions located in the central core consists of a distorted $\mathrm{N}_{4} \mathrm{O}$ trigonal bipyramid, with one oxygen of the hydroxo ion and four nitrogen atoms from two $\mathrm{bpp}^{-}$ligands. The two apical Co ions are coordinated to six nitrogen atoms from three $\mathrm{bpp}^{-}$ligands, in a distorted octahedral geometry. Each tetradentate $\mathrm{bpp}^{-}$ ligand is thus coordinated to one apical and one equatorial Co ion through one $\mathrm{N}$-pyridine and one $\mathrm{N}$-pyrazolyl. In contrast to $\mathbf{1}^{3+}$ and $1^{5+}$, the $1^{2+}$ cation adopts a 2 -fold symmetric structure with a $C_{2}$ axis passing through one Co of the central core, namely $\mathrm{Co}(3)$, and the $\mu_{3}-\mathrm{OH}$ ion. The apical metalligand bond distances $\left[\mathrm{Co}_{\mathrm{ap}}-\mathrm{N}\right.$ (Figure 1A)] for complexes $\mathbf{1}^{2+}$ and $\mathbf{1}^{3+}$ are very similar [Co $(1)$, average of 2.15(5) $\AA$ for $1^{2+}$; $\mathrm{Co}(4)$, average of $2.15(5) \AA$, and $\mathrm{Co}(5)$, average of 2.15(5) $\AA$ for $\mathbf{1}^{3+}$ ] and consistent with two high-spin Co(II) ions $(S=3 / 2)($ Table 1$){ }^{27}$ These distances are significantly shorter in $1^{5+}[\mathrm{Co}(1)$, average of $1.94(3) \AA$, and $\mathrm{Co}(5)$, average of $1.95(3) \AA$ (Table 1)], suggesting two low-spin Co(III) metal ions $(S=0)$. To confirm this, we have crystallized the neutral mononuclear $\left[\mathrm{Co}^{\mathrm{III}}(\mathrm{bpp})_{3}\right]$ (2) compound, a structural model of the apical $\left\{\mathrm{Co}(\mathrm{bpp})_{3}\right\}^{x+}$ units in $\mathbf{1}^{5+}$ (Figure $1 \mathrm{D}$ and Tables S5 and S6). In this complex, the average $\mathrm{Co}(\mathrm{III})-\mathrm{N}$ bond distance is $1.92(3) \AA$, i.e., very similar to those found in $\mathbf{1}^{5+}$ for the apical Co sites (Table 1). With regard to the trinuclear central core, the average of the $\mathrm{Co}_{\mathrm{eq}}-\mathrm{N}, \mathrm{O}$ bond distances in $\mathbf{1}^{3+}$ and $\mathbf{1}^{5+}$ is in the range of $2.054-2.06 \AA$, while the average of the $\mathrm{Co}-\mu$-OH bond distances is in the range of 2.022-2.051 $\AA$ (Table 1), 
consistent with a high-spin $\mathrm{Co}(\mathrm{II})$ within the $\mathrm{Co}_{3}{ }_{3}(\mu-\mathrm{OH})$ core. ${ }^{28}$ Although the average of the $\mathrm{Co}_{\mathrm{eq}}-\mathrm{N}, \mathrm{O}$ distances is quite similar in $\mathbf{1}^{2+}(2.04-2.07 \AA)$, the $\mathrm{Co}-\mu-\mathrm{OH}$ bond distances (1.958-2.056 $\AA$ ) and $\mathrm{Co}-(\mu-\mathrm{OH})-\mathrm{Co}$ angles are more dispersed, leading to a larger distortion of the triangular $\mathrm{Co}_{3}\left(\mu_{3}-\mathrm{OH}\right)$ core in $\mathbf{1}^{2+}$ compared to those of $\mathbf{1}^{3+}$ and $\mathbf{1}^{5+}$ (Table 1). These structural changes along with the presence of $\mathrm{Co}(\mathrm{II})$ ions in apical positions in $\mathbf{1}^{2+}$ strongly suggest that the reduction of a $\mathrm{Co}(\mathrm{II})$ ion to a $\mathrm{Co}(\mathrm{I})$ ion occurs in the central core. In addition, the similarity of average bond distances for each Co of the central core of $\mathbf{1}^{2+}$ could be an indication of a fully delocalized $\mathrm{Co}_{2}{ }^{\mathrm{II}} \mathrm{Co}^{\mathrm{I}}$ system (Table 2). The intermetallic Co $\cdots$ Co distances also reveal an elongation of the structure that is accompanied by a compression of the core in the reduced form, $\mathbf{1}^{2+}$, compared to $\mathbf{1}^{3+}$. The opposite behavior is observed for the oxidized species $\mathbf{1}^{5+}$. A large number of polynuclear cobalt complexes with various ligands and nuclearities have been reported r,29,30 $^{3}$ and, among them, many with trinuclear $\mathrm{Co}_{3}{ }_{3}\left(\mu_{3}-\mathrm{O}\right)^{31-33}$ and $\mathrm{Co}_{3}{ }_{3}\left(\mu_{3}\right.$ $\mathrm{OH})^{28,34-36}$ cores. However, to the best of our knowledge, all of these $\mu_{3}$-oxo and $\mu_{3}$-hydroxo-centered trinuclear complexes incorporate hexacoordinated Co ions. The $1^{3+}$ and $1^{5+}$ cations are thus the first example of compounds featuring a $\mathrm{Co}_{3}{ }^{\mathrm{II}}\left(\mu_{3}-\mathrm{OH}\right)$ core with five-coordinated metal ions. In addition, $\mathbf{1}^{2+}$ is the first illustration of a hydroxocentered $\left\{\mathrm{Co}^{\mathrm{I}} \mathrm{Co}_{2}{ }^{\mathrm{II}}\left(\mu_{3}-\mathrm{OH}\right)\right\}^{4+}$ trinuclear unit with one Co at the $+\mathrm{I}$ oxidation state. Isolated $\mathrm{Co}(\mathrm{I})$ complexes are rare, ${ }^{37-39}$ and the stabilization of a $\mathrm{Co}(\mathrm{I})$ within a trinuclear $\mu$-hydroxo core is probably the result of the particular structure of this pentanuclear complex in the presence of the two apical sites that maintain the trinuclear core through the six bridging bpp ${ }^{-}$ ligands.

Electrochemical Properties of $1^{3+}$ in $\mathrm{CH}_{3} \mathrm{CN}$ and Spectroscopic Characterizations by UV-Vis and EPR of $1^{3+}, 1^{5+}$, and $1^{2+}$. The cyclic voltammogram of $1^{3+}$ investigated in $\mathrm{CH}_{3} \mathrm{CN}$ under an argon atmosphere revealed the high stability of the complex in several redox states with up to seven reversible one-electron processes (Figure 2 and Figure S2). On the basis of the X-ray structure analysis of doubly oxidized complex $1^{5+}$, the two oxidation waves at $E_{1 / 2}$ values of $-0.21\left(\Delta E_{\mathrm{p}}=60 \mathrm{mV}\right)\left(1^{3+/ 4+}\right)$ and $-0.11 \mathrm{~V}\left(\Delta E_{\mathrm{p}}=60 \mathrm{mV}\right)$

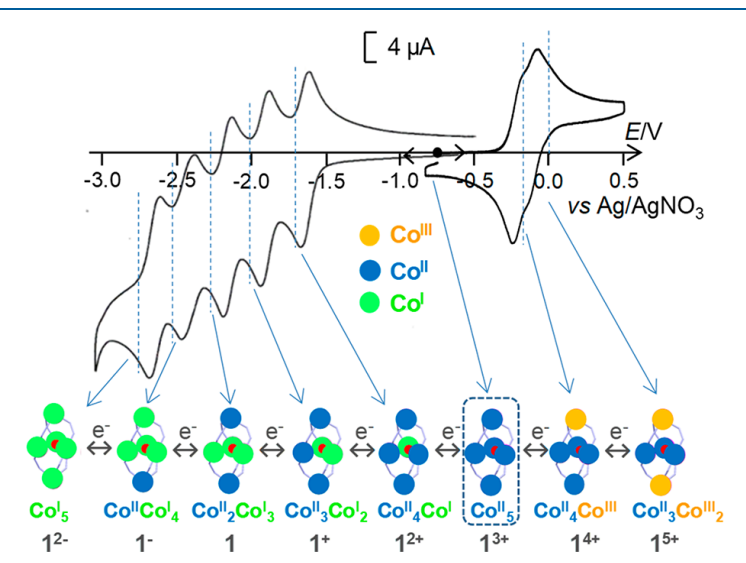

Figure 2. Cyclic voltammograms in $\mathrm{CH}_{3} \mathrm{CN}$ and $0.05 \mathrm{M}\left[\mathrm{Bu}_{4} \mathrm{~N}\right] \mathrm{ClO}_{4}$ of a $0.5 \mathrm{mM}$ solution of $\mathbf{1}^{3+}$ at a platinum electrode (diameter of 3 $\mathrm{mm}$ ) for a scan range between -0.82 and $0.5 \mathrm{~V}$ and at a vitreous carbon electrode (diameter of $3 \mathrm{~mm}$ ) for the scan range from -0.5 to $-3 \mathrm{~V}$ with a scan rate of $100 \mathrm{mV} \mathrm{s}^{-1}$. $\left(1^{4+/ 5+}\right)$ versus $\mathrm{Ag} / \mathrm{AgNO}_{3}$ have been unambiguously assigned to the successive oxidation of the two apical $\mathrm{Co}(\mathrm{II})$ ions to Co(III). As previously observed for $\left[\left\{\mathrm{Mn}(\mu \text {-bpp })_{3}\right\}_{2} \mathrm{Mn}_{3}\left(\mu_{3}\right.\right.$ $\mathrm{O})]^{2+}, 12$ the presence of two one-electron waves, close in potential $\left(\Delta E_{1 / 2}=100 \mathrm{mV}\right)$, instead of a single two-electron wave, agrees with a weak electronic coupling between the two electroactive apical $\mathrm{M}$ (II) centers, which can communicate through the conjugation of the bridging $\mathrm{bpp}^{-}$ligand and the central core. It is noteworthy that none of the oxidation processes of the $\mathrm{Co}(\mathrm{II})$ ions located in the central core can be experimentally accessed in the solvent electroactivity domain [no signal up to $+1.6 \mathrm{~V}$ (Figure S3A)]. This result is consistent with the protonation of the central oxygen $\left(\mu_{3}-\mathrm{OH}\right)$, which renders the oxidation of the metal ions more difficult than for the $\mathrm{Mn}$ and $\mathrm{Fe}$ pentanuclear analogues featuring a $\mu_{3}$-oxocentered core for which the five $\mathrm{M}^{\mathrm{II}} / \mathrm{M}^{\mathrm{III}}$ processes are observed (see below). ${ }^{12,17}$

Interestingly, for this Co complex, five successive reversible reduction waves are observed, at $E_{1 / 2}$ values of $-1.63,-1.88$, $-2.14,-2.40$, and $-2.60 \mathrm{~V}\left(\Delta E_{\mathrm{p}}=50-60 \mathrm{mV}\right.$ for each of them) (Table 3). Because the scan was restricted to $-2.4 \mathrm{~V}$ versus $\mathrm{Fc} / \mathrm{Fc}^{+}$, only the first three reversible reduction waves were detected by the group of Masaoka. ${ }^{26}$ According to the Xray structural characterization of $\mathbf{1}^{2+}$ and $\mathrm{UV}$-vis spectroscopy (see below), the first reduction process can be unambiguously attributed to the reduction of one $\mathrm{Co}(\mathrm{II})$ to $\mathrm{Co}(\mathrm{I})$ in the central core $\left[E_{1 / 2}=-1.63 \mathrm{~V}\left(\mathbf{1}^{3+} / \mathbf{1}^{2+}\right)\right]$. Hence, the further processes can be reasonably assigned to the reduction of the two last $\mathrm{Co}$ (II) ions of the central core $\left[E_{1 / 2}=-1.88 \mathrm{~V}\left(1^{2+/+}\right)\right.$ and $\left.-2.14 \mathrm{~V}\left(1^{+/ 0}\right)\right]$ and, at a more negative potential, to the reduction of the two apical $\mathrm{Co}(\mathrm{II})$ ions $\left[E_{1 / 2}=-2.40 \mathrm{~V}\left(\mathbf{1}^{0 /-}\right)\right.$ and $\left.-2.60 \mathrm{~V}\left(1^{-/ 2-}\right)\right]$. If such multiredox reversible behavior was also previously observed for the $\mathrm{Mn}$ and $\mathrm{Fe}$ pentanuclear analogues, ${ }^{12,17}$ it must be stressed that only five reversible metal-centered $\mathrm{M}^{\mathrm{II}} / \mathrm{M}^{\mathrm{II}}$ processes were detected, all being located in a more positive potential range (between -0.58 and $1.33 \mathrm{~V} \mathrm{vs} \mathrm{Ag} / \mathrm{AgNO}_{3}$ ) (Figure 3 and Table 3).

More precisely, for the $\mathrm{Mn}$ derivative, the first three processes, well-separated $\left(\Delta E_{1 / 2}\right.$ in the range of $0.48-0.70$ $\mathrm{V}$ ), are related to $\mathrm{Mn}^{\mathrm{III}} / \mathrm{Mn}^{\mathrm{II}}$ processes within the central core, while the last two oxidation processes, close in potential $\left(\Delta E_{1 / 2}\right.$ of $0.12 \mathrm{~V})$, are related to the oxidation of the two apical $\mathrm{Mn}^{\mathrm{II}}$ ions (Figure 3A). For the iron derivative, all oxidations occur in the core except for the second oxidation process, $\mathrm{Fe}^{\mathrm{II}}{ }_{3} \mathrm{Fe}^{\mathrm{III}}{ }_{2}$ to $\mathrm{Fe}_{2}{ }_{2} \mathrm{Fe}^{\mathrm{III}}{ }_{3}$, that presents a striking electronic switch, with both metal ions in apical position being oxidized while the core is reduced to $\left[\mathrm{Fe}^{\mathrm{III}} \mathrm{Fe}_{2}{ }_{2}\left(\mu_{3}-\mathrm{O}\right)\right]^{5+}$ (Figure $3 \mathrm{~B}$ ). Unfortunately, the electrochemical behavior of the analogous nickel complex, $\left[\left\{\mathrm{Ni}^{\mathrm{II}}(\mu \text {-bpp })_{3}\right\}_{2} \mathrm{Ni}^{\mathrm{II}}{ }_{3}\left(\mu_{3}-\mathrm{OH}\right)\right]^{3+13}$ is still unknown and thus cannot be compared to that of $\mathbf{1}^{3+}$. With regard to the zinc derivative, because $\mathrm{Zn}^{2+}$ is a redox-inactive metal, the $\left[\left\{\mathrm{Zn}^{\mathrm{II}}(\mu\right.\right.$ bpp $\left.\left.)_{3}\right\}_{2} \mathrm{Zn}_{3}{ }_{3}\left(\mu_{3}-\mathrm{OH}\right)\right]^{3+}$ complex does not exhibit any redox systems in the potential range of 1.2 to $-2.3 \mathrm{~V}$ (Table 3). ${ }^{26}$ The other complexes of cobalt isolated with the bpp ${ }^{-}$ligand and for which the redox properties have been studied are limited, to the best of our knowledge, to the dinuclear $\left[\mathrm{Co}_{2}{ }_{2}(\mu \text {-bpp })(\text { terpy })_{2}\left(\mathrm{OH}_{2}\right)(\mathrm{OH})\right]^{4+23}$ and $\left[\mathrm{Co}_{2}{ }_{2}(\mu\right.$-bpp $)-$ (terpy $\left.)_{2}\left(\mu-1,2-\mathrm{O}_{2}\right)\right]^{3+22}$ complexes isolated with terpyridine as a co-chelating ligand. While the bis-aquo complex displays four metal-centered process in the potential range of -1.46 to $0.0 \mathrm{~V}$ versus $\mathrm{Ag} / \mathrm{AgNO}_{3}$, involving the same redox states $\mathrm{Co} / \mathrm{Co}^{\mathrm{II}} /$ $\mathrm{Co}^{\text {III }}$, interestingly, the $\mu-1,2$-peroxo derivative exhibits three redox systems based on the $\mathrm{Co}^{\mathrm{II}} / \mathrm{Co}^{\mathrm{II}} / \mathrm{Co}^{\mathrm{IV}}$ redox states in a 
Table 3. Electrochemical Properties of the Triple-Helicate Pentanuclear Complexes $\left[\left\{\mathbf{M}(\boldsymbol{\mu} \text {-bpp })_{3}\right\}_{2} \mathbf{M}_{3}\left(\mu_{3}-\mathbf{X}\right)\right]^{n+}[\mathbf{M}=\mathbf{F e}$ and $\mathrm{Mn}(\mathrm{X}=\mathrm{O})$ or $\mathrm{Co}(\mathrm{X}=\mathrm{OH})]$ in $\mathrm{CH}_{3} \mathrm{CN}$ and Related Cobalt Complexes with bpp ${ }^{-}$Ligand

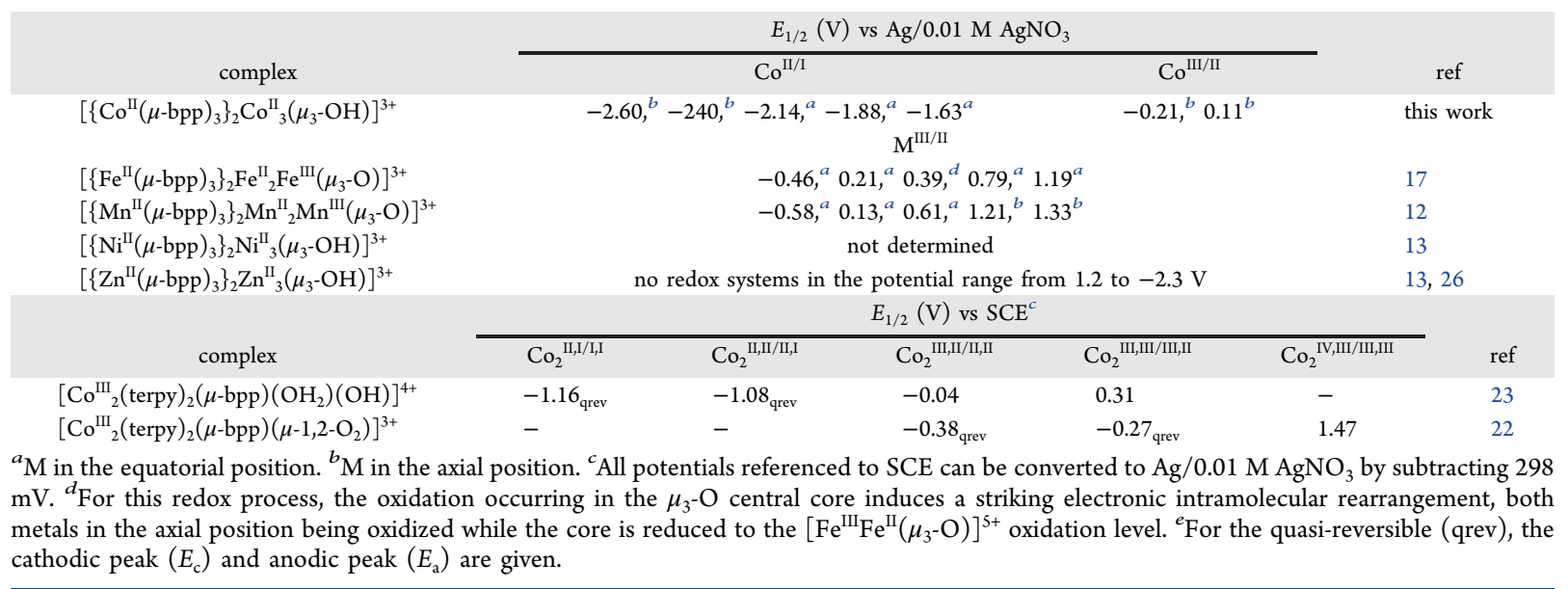

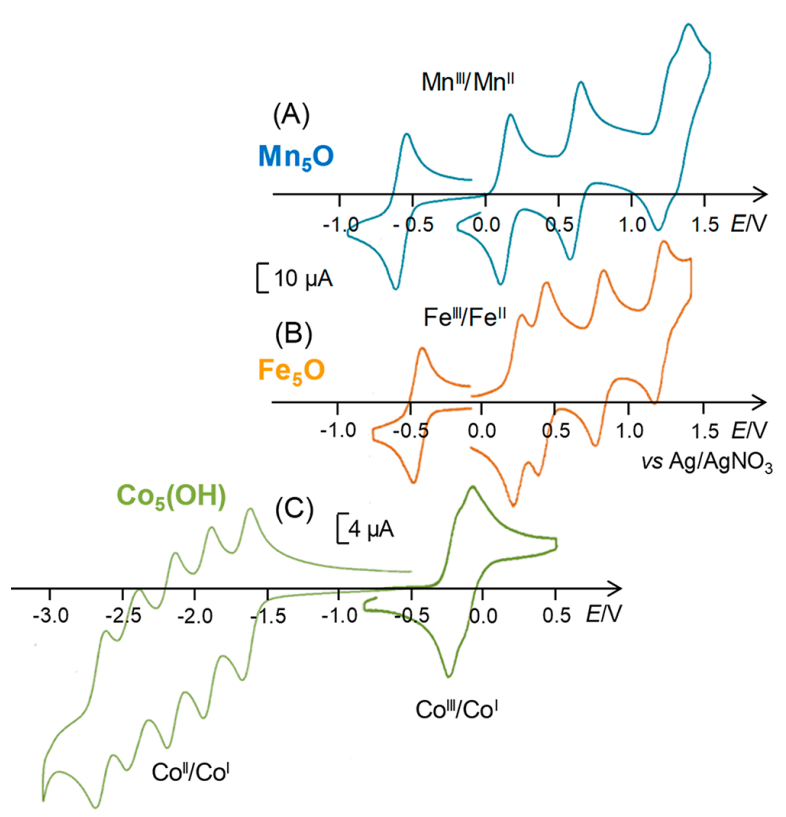

Figure 3. Cyclic voltammograms in $\mathrm{CH}_{3} \mathrm{CN}$ and $0.05 \mathrm{M}\left[\mathrm{Bu}_{4} \mathrm{~N}\right] \mathrm{ClO}_{4}$ of (A) a $0.7 \mathrm{mM}$ solution of $\left[\left\{\mathrm{Mn}^{\mathrm{II}}(\mu \text {-bpp })_{3}\right\}_{2} \mathrm{Mn}_{2}{ }_{2} \mathrm{Mn}^{\mathrm{III}}\left(\mu_{3}-\mathrm{O}\right)\right]^{3+}$ at a Pt electrode (diameter of $5 \mathrm{~mm}),(\mathrm{B})$ a $0.5 \mathrm{mM}$ solution of $\left[\left\{\mathrm{Fe}^{\mathrm{II}}(\mu \text {-bpp })_{3}\right\}_{2} \mathrm{Fe}_{2}{ }_{2}^{\mathrm{II}} \mathrm{Fe}^{\mathrm{III}}\left(\mu_{3}-\mathrm{O}\right)\right]^{3+}$ at a Pt electrode (diameter of 5 $\mathrm{mm})$, and $(\mathrm{C})$ a solution of $\left[\left\{\mathrm{Co}^{\mathrm{II}}(\mu \text {-bpp })_{3}\right\}_{2} \mathrm{Co}_{3}{ }_{3}\left(\mu_{3}-\mathrm{OH}\right)\right]^{3+}\left(\mathbf{1}^{3+}\right)$ at a Pt electrode (diameter of $3 \mathrm{~mm}$ ) with a scan rate of $100 \mathrm{mV} \mathrm{s}^{-1}$.

more positive potential range of -0.68 to $1.17 \mathrm{~V}$ versus $\mathrm{Ag} /$ $\mathrm{AgNO}_{3}$ (Table 3). The two reduction processes of the bisaquo complex are quasi-reversible highlighting the poor stability of the complex when reduced to $\mathrm{Co}(\mathrm{I})$, in sharp contrast with the electrochemical behavior of $\mathbf{1}^{3+}$. The other structurally characterized complexes of $\mathrm{bpp}^{-}$with a first-row transition metal (without an additional chelating ligand) mainly rely on dinuclear complexes with two coplanar bpp ${ }^{-}$ ligands bridging the metal centers and two or four axially coordinated ligands (Table 4). If their magnetic properties have been explored showing generally strongly antiferromagntic coupling constants and, in the case of iron derivatives, a
Table 4. Magnetic Properties of Structurally Characterized First-Row Transition Metal Complexes with the bpp ${ }^{-}$ Ligand $^{a}$

\begin{tabular}{|c|c|c|}
\hline complex & $\begin{array}{c}\text { magnetic coupling } \\
\text { constant } J\left(\mathrm{~cm}^{-1}\right) / \\
\text { observed spin } \\
\text { crossover }(\mathrm{SCO}) \\
\text { phenomenon }\end{array}$ & ref \\
\hline$\left[\mathrm{Ni}_{2}{ }_{2}(\mu \text {-bpp })_{2}\left(\mathrm{H}_{2} \mathrm{O}\right)(\mathrm{MeOH})_{4}\right]^{2+}$ & $-1-$ & 40 \\
\hline$\left[\mathrm{Ni}_{2}{ }_{2}(\mu \text {-bpp })_{2}\left(\mathrm{~N}_{3}\right)_{2}(\mathrm{MeOH})_{2}\right]$ & $-22.6 \mathrm{~cm}^{-1}$ & 41 \\
\hline$c i s-\left[\mathrm{Cu}_{2}{ }_{2}(\mu-\mathrm{bpp})_{2}\left(\mathrm{H}_{2} \mathrm{O}\right)_{2}\right]^{2+}$ & $-368.3 \mathrm{~cm}^{-1}$ & 42 \\
\hline$\left\{c i s\left[\mathrm{Cu}_{2}{ }_{2}(\mu \text {-bpp })_{2}\left(\mathrm{H}_{2} \mathrm{O}\right)_{2}\right]\left(\mathrm{NO}_{3}\right)_{2} \cdot 2 \mathrm{H}_{2} \mathrm{O}\right\}_{2}$ & $-180 \mathrm{~cm}^{-1}$ & 43 \\
\hline$\left\{\text { trans }-\left[\mathrm{Cu}_{2}{ }_{2}(\mu \text {-bpp })_{2}\left(\mathrm{ClO}_{4}\right)_{2}\right]\right\}_{2}$ & $-/-$ & 44 \\
\hline trans- $\left[\mathrm{Fe}_{2}{ }_{2}(\mu \text {-bpp })_{2}(\mathrm{NCS})_{2}(3 \mathrm{Brpy})_{2}\right]$ & SCO & 45 \\
\hline trans- $\left[\mathrm{Fe}_{2}{ }_{2}(\mu \text {-bpp })_{2}(\mathrm{NCS})_{2}(\mathrm{DMSO})_{2}\right]$ & $-3.5 \mathrm{~cm}^{-1}$ & 46 \\
\hline trans- $\left[\mathrm{Fe}_{2}{ }_{2}(\mu \text {-bpp })_{2}\left(\mathrm{NCBH}_{3}\right)_{2}(\mathrm{py})_{2}\right]$ & SCO & 46 \\
\hline trans- $\left[\mathrm{Fe}_{2}{ }_{2}(\mu \text {-bpp })_{2}\left(\mathrm{NCBH}_{3}\right)_{2}(4-\mathrm{Phpy})_{2}\right]$ & SCO & 47 \\
\hline trans $\left[\mathrm{Fe}_{2}{ }_{2}(\mu \text {-bpp })_{2}(\mathrm{NCSe})_{2}(\mathrm{py})_{2}\right]$ & SCO & 48 \\
\hline trans- $\left[\mathrm{Fe}_{2}{ }_{2}(\mu-\mathrm{bpp})_{2}(\mathrm{NCS})_{2}(\mathrm{py})_{2}\right]$ & SCO as powder & $\begin{array}{l}45 \\
48\end{array}$ \\
\hline trans- $\left[\mathrm{Co}_{2}{ }_{2}(\mu \text {-bpp })_{2}(\mathrm{NCS})_{2}(4-\mathrm{Phpy})_{2}\right]$ & $-8.78 \mathrm{~cm}^{-1}$ & 49 \\
\hline$\left[\mathrm{Fe}_{2}{ }_{2}(\mu \text {-bpp })_{2}\left(\mathrm{NCBH}_{3}\right)_{2}(4-\mathrm{Phpy})_{2}\right]$ & SCO & 49 \\
\hline$\left(\text { trans }-\left[\mathrm{Fe}_{2}{ }_{2}(\mu \text {-bpp })_{2}(\mathrm{NCS})_{2}\left(\mu-4,4^{\prime} \text {-bpy }\right)_{2}\right]\right)_{\infty}$ & $\mathrm{SCO}$ & 50 \\
\hline$\left[\mathrm{Fe}_{2}{ }_{2}(\mu \text {-bpp })_{2}(\mathrm{TCNQ})_{2}\right](\mathrm{TCNQ})_{2}$ & SCO & 51 \\
\hline$\left[\mathrm{Cu}_{4}(\mu \text {-bpp })_{4}(\mathrm{TCVA})_{2}\right]$ & $-217.7 \mathrm{~cm}^{-1}$ & 52 \\
\hline syn- $\left[\mathrm{Cu}_{2}(\mu \text {-bpp })_{2}(\mathrm{DCNM})_{2}\right]$ & $-210.3 \mathrm{~cm}^{-1}$ & 52 \\
\hline anti- $\left[\mathrm{Cu}_{2}(\mu \text {-bpp })_{2}(\mathrm{DCNE})\right]$ & $-188.5 \mathrm{~cm}^{-1}$ & 52 \\
\hline$\left[\mathrm{Cu}_{2}(\mu \text {-bpp })_{2} \mathrm{Br}_{1.25}\left(\mathrm{H}_{2} \mathrm{O}\right)_{0.75}\right] \mathrm{Br}_{0.75}$ & $-390 \mathrm{~cm}^{-1}$ & 53 \\
\hline$\left[\mathrm{Zn}_{2}(\mu \text {-bpp })_{2}\left(\mathrm{~N}\left(\mathrm{SiMe}_{3}\right)_{2}\right)_{2}\right]$ & $-1-$ & 53 \\
\hline$\left[\mathrm{Zn}_{2}(\mu \text {-bpp })_{2}\left(\mathrm{CH}\left(\mathrm{SiMe}_{3}\right)_{2}\right)_{2}\right]$ & $-1-$ & 53 \\
\hline
\end{tabular}

${ }^{a}$ Abbreviations: 3Brpy, 3-bromo-pyridine; py, pyridine; 4Phpy, 4phenylpyridine; bpy, bipyridine; TCNQ $7,7^{\prime}, 8,8^{\prime}$-tetracyano-pquinodimethane; TCVA, 1,2,2-tricyanoethenolate; DCNM, 2,2dicyano-1-methoxyethenolate; DCNE, 2,2-dicyano-1-ethoxyethenolate.

spin crossover behavior, the electrochemical properties of these complexes have never been investigated.

Species $\mathbf{1}^{5+}$ and $1^{2+}$ were quantitatively generated by exhaustive electrolyses of a $\mathbf{1}^{3+}$ solution at 0.25 and $-1.75 \mathrm{~V}$, respectively (two- and one-electron-exchanged), as illustrated by the resulting cyclic voltammograms (Figures S3 and S4), confirming the high stability of such triple-helicate pentanu- 
clear structures in several oxidation states. A further electrolysis at $-2.05 \mathrm{~V}$ generates the two-electron-reduced species $\mathbf{1}^{+}$that fully precipitated at the end of the electrolysis.

The electrogenerated solutions of $\mathbf{1}^{3+}, \mathbf{1}^{5+}$, and $\mathbf{1}^{2+}$ have distinct UV-vis and EPR signatures (Figure 4A and Figure

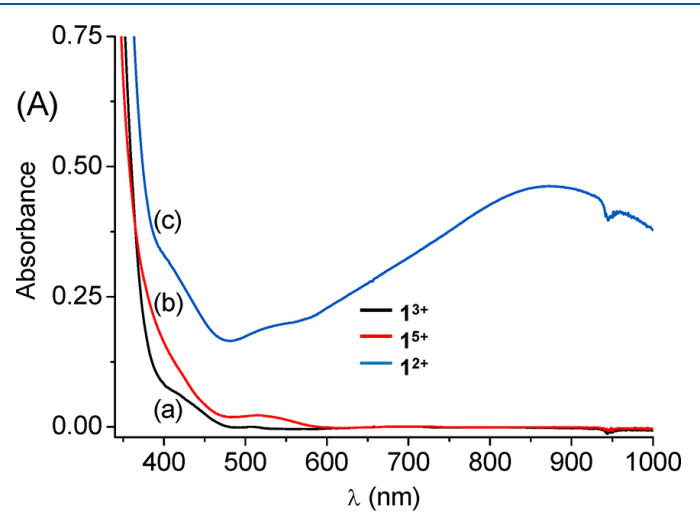

(B)

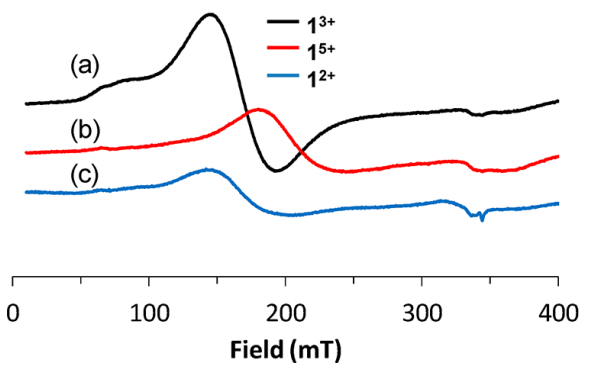

Figure 4. (A) Visible absorption $(l=1 \mathrm{~mm})$ and (B) X-band EPR spectra of (a) a $0.5 \mathrm{mM}$ solution of $\mathbf{1}^{3+}$ in $\mathrm{CH}_{3} \mathrm{CN}$ and $0.05 \mathrm{M}$ $\left[\mathrm{Bu}_{4} \mathrm{~N}\right] \mathrm{ClO}_{4}$, (b) after oxidation at $0.25 \mathrm{~V}$ vs $\mathrm{Ag} / \mathrm{AgNO}_{3}$ (formation of $\left.\mathbf{1}^{5+}\right)$, and (c) after reduction at $-1.75 \mathrm{~V}$ of $\mathbf{1}^{3+}$ (formation of $\mathbf{1}^{2+}$ ). EPR conditions: microwave frequency, $9.63 \mathrm{GHz}$; power, $6.5 \mathrm{~mW}$; modulation amplitude, $0.4 \mathrm{mT}$; frequency, $100 \mathrm{kHz} ; \mathrm{T}=8 \mathrm{~K}$.

S5). Spectroscopic characterizations of solutions of $\mathbf{1}^{+}$were prevented by its insolubility (Figure S5C). Upon oxidation of $\mathbf{1}^{3+}$ to $\mathbf{1}^{5+}$, an increase in the absorbance within the 450-600 $\mathrm{nm}$ domain is observed, consistent with the conversion of Co(II) to Co(III) (Figure S5A). Upon reduction of $\mathbf{1}^{3+}$ to $\mathbf{1}^{2+}$, a broad band grows in the 700-900 $\mathrm{nm}$ region, in agreement with the generation of a $\mathrm{Co}(\mathrm{I})$ species (Figure S5B). ${ }^{37,38,54}$ The X-band EPR spectra of complexes $1^{2+}, 1^{3+}$, and $1^{5+}$ in a frozen $\mathrm{CH}_{3} \mathrm{CN}$ solution are depicted in Figure 4B. We will first comment on the spectrum of $\mathbf{1}^{5+}$, because it features only the contribution of the paramagnetic trinuclear core $\left\{\mathrm{Co}_{3}{ }_{3}\left(\mu_{3^{-}}\right.\right.$ $\mathrm{OH})\}^{5+}$ as the two remaining apical Co(III) ions are diamagnetic. The spectrum shows a broad resonance at an approximate $g$ effective value of 4 . It falls in the range of highspin $\mathrm{Co}(\mathrm{II})(S=3 / 2)$ complexes, ${ }^{38,55}$ further confirming the high-spin electronic configuration of the cobalt ions within the $\mathrm{Co}_{3}{ }_{3}$ core. Unfortunately, it was not possible to gain further information about the magnetic coupling in the $\mathrm{Co}_{3}{ }_{3}$ core by EPR spectroscopy due to the significant line width and large zero-field splitting (ZFS) parameters. Complex $\mathbf{1}^{3+}$ differs from $\mathbf{1}^{5+}$ in the presence of two high-spin apical paramagnetic $\mathrm{Co}$ (II) centers, which are expected to be only very weakly magnetically coupled with the trinuclear $\mathrm{Co}_{3}{ }_{3}$ core. ${ }^{28}$ Its spectrum is characterized by a main resonance at $g=4$, together with a shoulder at $g=6 .^{28}$ The increase in the intensity of the signal $\left(\sim^{3} / 2\right.$ more intense in comparison to complex $\left.\mathbf{1}^{5+}\right)$ is consistent with an increased paramagnetism due to the presence of the two weakly coupled apical Co(II) centers in $\mathbf{1}^{3+}$. It is worth noting that the shape of the spectrum differs between $1^{3+}$ and $1^{5+}$. This may be interpreted by the existence of weak dipolar interactions between the $\mathrm{Co}_{3}{ }_{3}$ core and the apical Co(II) centers in $\mathbf{1}^{3+}$ and/or more simply by the fact that oxidations of both apical positions affect the geometry of the core. The EPR spectrum of $\mathbf{1}^{2+}$ mainly revealed a quenching of the line when compared to $\mathbf{1}^{3+}$. As the core has been one-electron-reduced in $\mathbf{1}^{2+}$, it can be described as a cobalt-based integer spin system, which is in general difficult to detect by X-band EPR spectroscopy.

Magnetic Properties of $1\left(\mathrm{ClO}_{4}\right)_{2} \cdot 2 \mathrm{CH}_{3} \mathrm{CN}, 1\left(\mathrm{BF}_{4}\right)_{3}$. $3.75 \mathrm{CH}_{3} \mathrm{CN} \cdot 0.33 \mathrm{H}_{2} \mathrm{O}$, and $1\left(\mathrm{ClO}_{4}\right)_{5} \cdot 6 \mathrm{CH}_{3} \mathrm{CN}$. The solidstate magnetic properties of $1\left(\mathrm{ClO}_{4}\right)_{2} \cdot 2 \mathrm{CH}_{3} \mathrm{CN}, \mathbf{1}\left(\mathrm{BF}_{4}\right)_{3}$. $3.75 \mathrm{CH}_{3} \mathrm{CN} \cdot 0.33 \mathrm{H}_{2} \mathrm{O}$, and $1\left(\mathrm{ClO}_{4}\right)_{5} \cdot 6 \mathrm{CH}_{3} \mathrm{CN}$ have been investigated using $\mathrm{dc}$ susceptibility $(\chi)$ measurements from 300 to $1.85 \mathrm{~K}$ and with applied magnetic fields of $\leq 7 \mathrm{~T}$ (Figure 5 and Figures S6-S8). The susceptibility data reported in

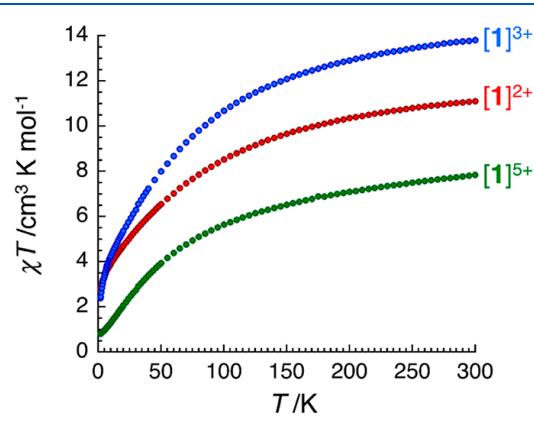

Figure 5. Temperature dependence of the $\chi T$ product (where $\chi$ is the molar magnetic susceptibility that equals $M / H$ per complex) collected in an applied dc magnetic field of $0.1 \mathrm{~T}$ for $1\left(\mathrm{ClO}_{4}\right)_{2} \cdot 2 \mathrm{CH}_{3} \mathrm{CN}$ (red), $\mathbf{1}\left(\mathrm{BF}_{4}\right)_{3} \cdot 3.75 \mathrm{CH}_{3} \mathrm{CN} \cdot 0.33 \mathrm{H}_{2} \mathrm{O}$ (blue), and $\mathbf{1}\left(\mathrm{ClO}_{4}\right)_{5} \cdot 6 \mathrm{CH}_{3} \mathrm{CN}$ (green) as indicated in the figure.

Figure 5 are shown as a $\chi T$ versus $T$ plot. At room temperature, the $\chi T$ products are 11.1, 13.8, and $7.8 \mathrm{~cm}^{3} \mathrm{~K}$ $\mathrm{mol}^{-1}$ for $\mathbf{1}\left(\mathrm{ClO}_{4}\right)_{2} \cdot 2 \mathrm{CH}_{3} \mathrm{CN}, \mathbf{1}\left(\mathrm{BF}_{4}\right)_{3} \cdot 3.75 \mathrm{CH}_{3} \mathrm{CN} \cdot 0.33 \mathrm{H}_{2} \mathrm{O}$, and $1\left(\mathrm{ClO}_{4}\right)_{5} \cdot 6 \mathrm{CH}_{3} \mathrm{CN}$, respectively. When the temperature is decreased, the $\chi T$ products decrease continuously to $1.85 \mathrm{~K}$ to reach $2.8,1.8$, and $0.81 \mathrm{~cm}^{3} \mathrm{~K} \mathrm{~mol}{ }^{-1}$, respectively. This thermal behavior is expected as the combined effects of antiferromagnetic interactions between $\mathrm{Co}(\mathrm{II})$ magnetic centers in the $\mathrm{Co}_{5}$ complex cores and the intrinsic thermal depopulation of the high-spin $\mathrm{Co}(\mathrm{II})$ excited states resulting from the splitting of the energy ground level. The absence of a high-temperature plateau in the $\chi T$ products reveals that the paramagnetic properties of these complexes never fall in the Curie limit even at $300 \mathrm{~K}$. Therefore, Curie constants of 13.2, 16.4 , and $9.6 \mathrm{~cm}^{3} \mathrm{~K} \mathrm{~mol}^{-1}$ for $1\left(\mathrm{ClO}_{4}\right)_{2} \cdot 2 \mathrm{CH}_{3} \mathrm{CN}, \mathbf{1}\left(\mathrm{BF}_{4}\right)_{3}$. $3.75 \mathrm{CH}_{3} \mathrm{CN} \cdot 0.33 \mathrm{H}_{2} \mathrm{O}$, and $1\left(\mathrm{ClO}_{4}\right)_{5} \cdot 6 \mathrm{CH}_{3} \mathrm{CN}$, respectively, were estimated from Curie-Weiss fits of the experimental data above $100 \mathrm{~K}$ (see Figures S6a, S7a, and S8a). These Curie constants agree perfectly well with the presence of four, five, and three high-spin Co(II) centers in the $1^{2+}, 1^{3+}$, and $1^{5+}$ cations, respectively $\left[C=3.3(1) \mathrm{cm}^{3} \mathrm{~K} \mathrm{~mol}^{-1}\right.$ per Co(II) site]. This Curie constant of $3.3 \mathrm{~cm}^{3} \mathrm{~K} \mathrm{~mol}^{-1}$ per Co(II) site implies 
an average $g_{\mathrm{Co}}$ value of 2.7, which is also consistent with typical values found for high-spin $\mathrm{Co}$ (II) metal ions. ${ }^{56,57}$ Moreover, these results also confirm the expected diamagnetism of the $\mathrm{d}^{8}$ $\mathrm{Co}(\mathrm{I})$ and $\mathrm{d}^{6} \mathrm{Co}(\mathrm{III})$ metal ions present in $\mathbf{1}^{2+}$ and $\mathbf{1}^{5+}$. In Figures S6-S8, the field dependence of the magnetization below $8 \mathrm{~K}$ and $\leq 7 \mathrm{~T}$ provides more information about the magnetic properties of these complexes. None of the magnetization data shows a saturation of the $M$ versus $H$ data [which reach only 5.5, 6.4, and $2.0 \mu_{\mathrm{B}}$ for $\mathbf{1}\left(\mathrm{ClO}_{4}\right)_{2}$. $2 \mathrm{CH}_{3} \mathrm{CN}, \quad \mathbf{1}\left(\mathrm{BF}_{4}\right)_{3} \cdot 3.75 \mathrm{CH}_{3} \mathrm{CN} \cdot 0.33 \mathrm{H}_{2} \mathrm{O}$, and $\mathbf{1}\left(\mathrm{ClO}_{4}\right)_{5}$. $6 \mathrm{CH}_{3} \mathrm{CN}$, respectively, at $1.85 \mathrm{~K}$ and $7 \mathrm{~T}$ ] or a superposition of the plots of $M$ versus $H / T$. These observations support the presence of a significant magnetic anisotropy as expected for high-spin $\mathrm{Co}$ (II) metal ions as well as the relevance of lowlying excited states induced by weak antiferromagnetic interactions within the complexes. The low magnetization value of $2.0 \mu_{\mathrm{B}}$ (at $1.85 \mathrm{~K}$ and $7 \mathrm{~T}$ ) for $\mathbf{1}\left(\mathrm{ClO}_{4}\right)_{5} \cdot 6 \mathrm{CH}_{3} \mathrm{CN}$ highlights the significant antiferromagnetic interactions in the $\left\{\mathrm{Co}_{3}{ }_{3}\left(\mu_{3}-\mathrm{OH}\right)\right\}$ central core, while the apical $\mathrm{Co}(\mathrm{III})$ atoms are magnetically silent. In comparison, the increase in magnetization to $6.4 \mu_{\mathrm{B}}$ for $1\left(\mathrm{BF}_{4}\right)_{3} \cdot 3.75 \mathrm{CH}_{3} \mathrm{CN} \cdot 0.33 \mathrm{H}_{2} \mathrm{O}$ is due to the additional paramagnetic contributions of the two apical high-spin $\mathrm{Co}(\mathrm{II})$ metal ions. For $\mathbf{1}\left(\mathrm{ClO}_{4}\right)_{2} \cdot 2 \mathrm{CH}_{3} \mathrm{CN}$, the reduction of the $\left\{\mathrm{Co}_{3}{ }_{3}\left(\mu_{3}-\mathrm{OH}\right)\right\}$ core to $\left\{\mathrm{Co}_{2}{ }_{2} \mathrm{Co}^{\mathrm{I}}\left(\mu_{3}\right.\right.$ $\mathrm{OH})\}$ leads as expected to a reduction of the magnetization from 6.4 to $5.5 \mu_{\mathrm{B}}$.

\section{CONCLUSION}

The $\left[\left\{\mathrm{Co}(\mu \text {-bpp })_{3}\right\}_{2} \mathrm{Co}_{3}\left(\mu_{3}-\mathrm{OH}\right)\right]^{n+}$ pentanuclear complex featuring a trinuclear $\mathrm{Co}_{3}\left(\mu_{3}-\mathrm{OH}\right)$ core wrapped by two $\left\{\mathrm{Co}(\mu \text {-bpp })_{3}\right\}$ units has been crystallized and characterized in three distinct redox states, $\mathrm{Co}^{\mathrm{I}} \mathrm{Co}_{4}{ }_{4}\left(1^{2+}\right), \mathrm{Co}_{5}{ }_{5}\left(1^{3+}\right)$, and $\mathrm{Co}_{3}{ }_{3} \mathrm{Co}_{2}{ }_{2}\left(1^{5+}\right)$. Notably, this complex exhibits up to seven successive reversible metal-centered redox processes by cyclic voltammetry and hence is capable of stabilizing eight consecutive redox states from $\mathrm{Co}_{5}{ }_{5}$ to $\mathrm{Co}_{3}{ }_{3} \mathrm{Co}^{\mathrm{III}}{ }_{2}$. The crystallographic characterization of the mixed-valent $\mathrm{Co}^{\mathrm{I}} \mathrm{Co}^{\mathrm{II}}{ }_{4}$ and $\mathrm{Co}_{3}{ }_{3} \mathrm{Co}_{2}{ }_{2}$ states has allowed the identification of the redox state of the Co sites in agreement with their spectroscopic and magnetic properties. The five processes located between -1.6 and $-2.6 \mathrm{~V}$ are related to the successive reduction of the five $\mathrm{Co}$ (II) ion of the complex to $\mathrm{Co}(\mathrm{I})$, starting by the central ions, highlighting the remarkable robustness of such architecture, especially in the low-valent $\mathrm{Co}(\mathrm{I})$ redox state. The two other redox systems between -0.2 and $-0.1 \mathrm{~V}$ are assigned to the successive oxidation of the apical $\mathrm{Co}(\mathrm{II})$ ions to $\mathrm{Co}(\mathrm{III})$. This redox behavior strongly differs from that of the $\mathrm{Mn}$ and $\mathrm{Fe}$ analogues featuring a $\mu_{3}$-oxo core that revealed five reversible metal-centered $\mathrm{M}^{\mathrm{III}} / \mathrm{M}^{\mathrm{II}}$ processes, all being located in a more positive potential range (between -0.58 and $1.33 \mathrm{~V}$ vs $\mathrm{Ag} / \mathrm{AgNO}_{3}$ ). Finally, spectroscopic and magnetic measurements agree with the presence of four, five, and three high-spin $\mathrm{Co}$ (II) centers in the $\mathrm{Co}^{\mathrm{I}} \mathrm{Co}_{4}{ }_{4}\left(1^{2+}\right), \mathrm{Co}_{5}{ }_{5}\left(1^{3+}\right)$, and $\mathrm{Co}_{3}{ }_{3} \mathrm{Co}^{\mathrm{III}}{ }_{2}\left(1^{5+}\right)$ cations, respectively, and also confirm the expected diamagnetism of the $\mathrm{d}^{8} \mathrm{Co}(\mathrm{I})$ and $\mathrm{d}^{6} \mathrm{Co}(\mathrm{III})$ metal ions present in $\mathbf{1}^{2+}$ and $\mathbf{1}^{5+}$. Future efforts will be devoted to the investigation of the deprotonation of the $\left(\mu_{3}-\mathrm{OH}\right)$ core of $\mathbf{1}^{3+}$ that should lead to a completely different electrochemical behavior. In addition, we will study in more detail the ability of this complex to act as a catalyst for $\mathrm{CO}_{2}$ reduction.

\section{EXPERIMENTAL SECTION}

Caution! Perchlorate salts of compounds containing organic ligands are potentially explosive. Although we have encountered no such problems, only small quantities of these compounds should be prepared and handled with care.

Synthesis of $\left[\left\{\mathrm{Co}^{\prime \prime}(\mu-\mathrm{bpp})_{3}\right\}_{2} \mathrm{Co}_{3}{ }_{3}\left(\mu_{3}-\mathrm{OH}\right)\right]\left(\mathrm{BF}_{4}\right)_{3} \quad\left(1^{3+}\right)$. A solution of $\mathrm{Co}\left(\mathrm{BF}_{4}\right)_{2} \cdot 6 \mathrm{H}_{2} \mathrm{O}(126 \mathrm{mg}, 0.37 \mathrm{mmol})$ in acetonitrile $(6$ $\mathrm{mL}$ ) was added to a stirred acetonitrile $(16 \mathrm{~mL})$ solution of $\mathrm{Hbpp}$ $(98.5 \mathrm{mg}, 0.44 \mathrm{mmol})$ and $\mathrm{Et}_{3} \mathrm{~N}(155 \mu \mathrm{L}, 1.11 \mathrm{mmol})$ in a $100 \mathrm{~mL}$ glass tube sealed with a Teflon cap leading to a reddish solution with a solid in suspension. The reaction mixture was heated at $170{ }^{\circ} \mathrm{C}$ for 3 days leading to a brownish solution with a small amount of a brownish precipitate. The resulting mixture was then cooled to room temperature and filtered to remove some insoluble white/brown solid. The resulting brown filtrate was concentrated under vacuum, and low vapor diffusion of diisopropyl ether into this solution afforded large dark orange single crystals of $\mathbf{1}\left(\mathrm{BF}_{4}\right)_{3} \cdot 3.75 \mathrm{CH}_{3} \mathrm{CN} \cdot 0.33 \mathrm{H}_{2} \mathrm{O}$ (yield of $107 \mathrm{mg}, 91 \%)$ : IR $\left(\mathrm{cm}^{-1}\right) 1603(\mathrm{~s}), 1565(\mathrm{w}), 1535(\mathrm{w})$, $1460(\mathrm{~m}), 1436(\mathrm{~s}), 1335(\mathrm{~m}), 1270(\mathrm{w}), 1257(\mathrm{w}), 1162(\mathrm{w}), 1047$ (vs), $1023(\mathrm{w}), 967(\mathrm{w}), 776(\mathrm{~s}), 737(\mathrm{w})$. Elemental analysis calcd (\%) for $\mathrm{C}_{78} \mathrm{H}_{55} \mathrm{~B}_{3} \mathrm{Co}_{5} \mathrm{~F}_{12} \mathrm{~N}_{24} \mathrm{O}_{1} \cdot 3 \mathrm{H}_{2} \mathrm{O}\left(1971.57 \mathrm{~g} \mathrm{~mol}^{-1}\right)$ : C, 47.96; H, 3.15; N, 17.21. Found: C, 47.90; H, 3.03; N, 17.25.

Electrochemical Synthesis of [\{Col'I $\left.\left.(\mu-\mathrm{bpp})_{3}\right\}_{2} \mathrm{Co}_{3}{ }_{3}\left(\mu_{3}-\mathrm{OH}\right)\right]-$ $\left(\mathrm{ClO}_{4}\right)_{5}\left(1^{5+}\right)$, [\{Co" $\left.\left.(\mu \text {-bpp })_{3}\right\}_{2} \mathrm{Co}_{2}{ }_{2} \mathrm{Co}^{\prime}\left(\mu_{3}-\mathrm{OH}\right)\right]\left(\mathrm{ClO}_{4}\right)_{2}\left(1^{2+}\right)$, and $\left[\left\{\mathrm{Col}^{\prime \prime}(\mu \text {-bpp })_{3}\right\}_{2} \mathrm{Co}^{\mathrm{II}} \mathrm{Co}_{2}\left(\mu_{3}-\mathrm{OH}\right)\right]\left(\mathrm{ClO}_{4}\right)\left(1^{+}\right)$. A solution of $\mathbf{1}\left(\mathrm{BF}_{4}\right)_{3}$ $(40 \mathrm{mg})$ in acetonitrile $(10 \mathrm{~mL})$ containing $0.05 \mathrm{M}\left[\mathrm{Bu}_{4} \mathrm{~N}\right] \mathrm{ClO}_{4}$ was oxidized at $0.3 \mathrm{~V}$ versus $\mathrm{Ag} / \mathrm{AgNO}_{3}$ on a reticulated vitreous carbon electrode in a glovebox under an argon atmosphere. After exhaustive electrolysis (two electrons exchanged per molecule of the initial complex $)$, the formation of $\left[\left\{\mathrm{Co}^{\mathrm{III}}(\mu \text {-bpp })_{3}\right\}_{2} \mathrm{Co}_{3}{ }_{3}(\mu-\mathrm{OH})\right]^{5+}\left(1^{5+}\right)$ is controlled by cyclic voltammetry and UV-vis spectroscopy. The orange solution is then filtered to remove the carbon residue. Single crystals of $\mathbf{1}\left(\mathrm{ClO}_{4}\right)_{5} \cdot 6 \mathrm{CH}_{3} \mathrm{CN}$ were obtained by slow vapor diffusion of diisopropyl ether into the electrogenerated solution (yield of 32 $\mathrm{mg}, 74 \%$ ). A similar electrochemical procedure has been used for the isolation of $\mathbf{1}^{2+}$ and $\mathbf{1}^{+}$at the exception of the electrolysis potential, which was set at -1.75 and $-2.05 \mathrm{~V}$ versus $\mathrm{Ag} / \mathrm{AgNO}_{3}$, respectively. Dark blue single crystals of $\mathbf{1}\left(\mathrm{ClO}_{4}\right)_{2} \cdot 2 \mathrm{CH}_{3} \mathrm{CN}$ were obtained by slow vapor diffusion of the electrogenerated solution (yield of $33 \mathrm{mg}$, $90 \%)$, while for $\mathbf{1}^{+}, \mathbf{1}\left(\mathrm{ClO}_{4}\right)$ precipitates as a dark blue powder in the course of the electrolysis: IR $\left(\mathrm{cm}^{-1}\right)$ for $\mathbf{1}\left(\mathrm{ClO}_{4}\right)_{5} \cdot 3 \mathrm{H}_{2} \mathrm{O} 1608(\mathrm{~s})$, $1569(\mathrm{w}), 1535(\mathrm{w}), 1460(\mathrm{~m}), 1439(\mathrm{~m}), 1335(\mathrm{~m}), 1274(\mathrm{w}), 1261$ (w), $1165(\mathrm{w}), 1067(\mathrm{vs}), 1023(\mathrm{w}), 967(\mathrm{w}), 773(\mathrm{~s}), 740(\mathrm{w})$. Elemental analysis calcd (\%) for $\mathbf{1}\left(\mathrm{ClO}_{4}\right)_{5} \cdot 3 \mathrm{H}_{2} \mathrm{O}$ $\left[\mathrm{C}_{78} \mathrm{H}_{55} \mathrm{Co}_{5} \mathrm{Cl}_{5} \mathrm{~N}_{24} \mathrm{O}_{21} \cdot 3 \mathrm{H}_{2} \mathrm{O}\right.$ (2190.394 $\left.\left.\mathrm{g} \mathrm{mol}^{-1}\right)\right]: \mathrm{C}, 42.77 ; \mathrm{H}$, 2.81; N, 15.35. Found: C, 42.76; H, 3.06; N, 15.43 .

Synthesis of $\left[\mathrm{Co}^{\mathrm{III}}(\mathbf{b p p})_{3}\right](2) . \mathrm{Na}_{3}\left[\mathrm{Co}^{\mathrm{III}}\left(\mathrm{NO}_{2}\right)_{6}\right](35.8 \mathrm{mg}$, $0.0886 \mathrm{mmol})$ is solubilized in a $3: 1$ acetonitrile $/ \mathrm{H}_{2} \mathrm{O}$ mixture $(8$ $\mathrm{mL}$ ), leading to an orange solution. This solution was then slowly added to a stirred solution of $\mathrm{Hbpp}(60 \mathrm{mg}, 0.27 \mathrm{mmol})$ in acetonitrile $(30 \mathrm{~mL})$, leading to the formation of an orange suspension. Upon addition of $\mathrm{Bu}_{4} \mathrm{NOH}(440 \mu \mathrm{L}, 0.444 \mathrm{mmol})$, the resulting dark brown mixture containing insoluble material was stirred at room temperature for $4 \mathrm{~h}$. The brownish precipitate was then filtered off. The resulting solution was concentrated under reduced pressure until $\sim 5 \mathrm{~mL}$, resulting in precipitation of a white solid, which was removed by filtration. Slow vapor diffusion of diisopropyl ether/ acetone into the resulting orange filtrate afforded $\mathrm{X}$-ray quality crystals of $2 \cdot 0.5 \mathrm{CH}_{3} \mathrm{CN} \cdot\left(\mathrm{CH}_{3}\right)_{2} \mathrm{CO} \cdot 0.5\left(\left(\mathrm{CH}_{3}\right)_{2} \mathrm{CH}\right)_{2} \mathrm{O}$ (yield of $34 \mathrm{mg}$, 53\%): IR $\left(\mathrm{cm}^{-1}\right) 1613(\mathrm{~s}), 1587(\mathrm{~s}), 1560(\mathrm{~m}), 1545(\mathrm{~m}), 1508$ (m), $1447(\mathrm{~m}), 1409(\mathrm{w}), 1373(\mathrm{w}), 1281(\mathrm{w}), 1254(\mathrm{w}), 1236(\mathrm{w})$, $1153(\mathrm{w}), 1142(\mathrm{w}), 1104(\mathrm{w}), 1090(\mathrm{w}), 1070(\mathrm{w}), 1056(\mathrm{w}), 1026$ (w), $992(\mathrm{~m}), 958(\mathrm{~m}), 767(\mathrm{~m}), 734(\mathrm{w})$. Elemental analysis calcd (\%) for $2\left[\mathrm{C}_{39} \mathrm{H}_{27} \mathrm{CoN}_{12}\left(722.66 \mathrm{~g} \mathrm{~mol}^{-1}\right)\right]$ : $\mathrm{C}, 64.82 ; \mathrm{H}, 3.77 ; \mathrm{N}$, 23.26. Found: C, 65.23; H, 3.74; N, 23.50 . 


\section{Accession Codes}

CCDC 1956211-1956214 contain the supplementary crystallographic data for this paper. These data can be obtained free of charge via www.ccdc.cam.ac.uk/data_request/cif, or by emailing data_request@ccdc.cam.ac.uk, or by contacting The Cambridge Crystallographic Data Centre, 12 Union Road, Cambridge CB2 1EZ, UK; fax: +44 1223336033.

\section{AUTHOR INFORMATION}

\section{Corresponding Author}

Marie-Noëlle Collomb - Univ. Grenoble Alpes, CNRS, DCM, 38000 Grenoble, France; $\odot$ orcid.org/0000-0002-6641-

771X; Email: marie-noelle.collomb@univ-grenoble-alpes.fr

\section{Authors}

Eric Gouré - Univ. Grenoble Alpes, CNRS, DCM, 38000 Grenoble, France

Bertrand Gerey - Univ. Grenoble Alpes, CNRS, DCM, 38000 Grenoble, France

Florian Molton - Univ. Grenoble Alpes, CNRS, DCM, 38000 Grenoble, France

Jacques Pécaut - Univ. Grenoble Alpes, CEA, CNRS, IRIG, SyMMES, 38000 Grenoble, France

Rodolphe Clérac - Univ. Bordeaux, CNRS, Centre de Recherche Paul Pascal, F-33600 Pessac, France; @ orcid.org/ 0000-0001-5429-7418

Fabrice Thomas - Univ. Grenoble Alpes, CNRS, DCM, 38000 Grenoble, France; 10 orcid.org/0000-0002-6977-5192

Jérôme Fortage - Univ. Grenoble Alpes, CNRS, DCM, 38000

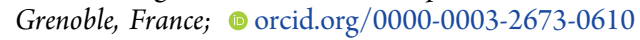

\section{Notes}

The authors declare no competing financial interest.

\section{ACKNOWLEDGMENTS}

This work has been partially supported by the French National Research Agency through Labex ARCANE and CBH-EUR-GS (ANR-17-EURE-0003) for Project MnCaPSII, as well as ANR13-BS07-0015-01 (MnCaOEC), including the postdoctoral grant to E.G. B.G. thanks the "Universite Grenoble Alpes" for his Ph.D. grant. The authors thank the IR-RPE CNRS FR3443 RENARD network for EPR facilities. The NanoBio-ICMG platforms (FR 2607) are acknowledged for their support. This work was also supported by the COST CM1202 program (PERSPECT $\mathrm{H}_{2} \mathrm{O}$ ). The authors also thank the University of Bordeaux, the Universite Grenoble Alpes, the CNRS, the CEA, the Region Nouvelle Aquitaine, MOLSPIN COST Action CA15128, and the GdR MCM-2.

\section{REFERENCES}

(1) Albrecht, M. Let's Twist Again”Double-Stranded, TripleStranded, and Circular Helicates. Chem. Rev. 2001, 101 (11), 3457-3498.

(2) Nakamura, T.; Ube, H.; Shionoya, M. Elaborate Metallosupramolecular Architectures through Desymmetrization Selfassembly of Symmetric Building Blocks. Chem. Lett. 2013, 42 (4), $328-334$.

(3) Miyake, H.; Tsukube, H. Coordination chemistry strategies for dynamic helicates: time-programmable chirality switching with labile and inert metal helicates. Chem. Soc. Rev. 2012, 41 (21), 6977-6991.

(4) Shiga, T.; Newton, G. N.; Oshio, H. Pre-programmed selfassembly of polynuclear clusters. Dalton Trans. 2018, 47 (22), 73847394.

(5) Haasnoot, J. G. Mononuclear, oligonuclear and polynuclear metal coordination compounds with 1,2,4-triazole derivatives as ligands. Coord. Chem. Rev. 2000, 200-202, 131-185.

(6) Beckmann, U.; Brooker, S. Cobalt(II) complexes of pyridazine or triazole containing ligands: spin-state control. Coord. Chem. Rev. 2003, 245 (1), 17-29.

(7) Klingele, J.; Dechert, S.; Meyer, F. Polynuclear transition metal complexes of metal - 'metal-bridging compartmental pyrazolate ligands. Coord. Chem. Rev. 2009, 253 (21-22), 2698-2741.

(8) Viciano-Chumillas, M.; Tanase, S.; de Jongh, L. J.; Reedijk, J. Coordination Versatility of Pyrazole-Based Ligands towards HighNuclearity Transition-Metal and Rare-Earth Clusters. Eur. J. Inorg. Chem. 2010, 2010 (22), 3403-3418.

(9) Garcia-Anton, J.; Bofill, R.; Escriche, L.; Llobet, A.; Sala, X. Transition-Metal Complexes Containing the Dinucleating Tetra-NDentate 3,5-Bis(2-pyridyl)pyrazole (Hbpp) Ligand - A Robust Scaffold for Multiple Applications Including the Catalytic Oxidation of Water to Molecular Oxygen. Eur. J. Inorg. Chem. 2012, 2012 (30), $4775-4789$.

(10) Yoneda, K.; Adachi, K.; Nishio, K.; Yamasaki, M.; Fuyuhiro, A. Katada, M.; Kaizaki, S.; Kawata, S. An $\left[\mathrm{Fe}_{3}{ }_{3} \mathrm{O}\right]^{4+}$ Core Wrapped by Two $\left[\mathrm{Fe}^{\mathrm{II}} \mathrm{L}_{3}\right]^{-}$Units. Angew. Chem., Int. Ed. 2006, 45 (33), 54595461.

(11) Ishikawa, R.; Nakano, M.; Fuyuhiro, A.; Takeuchi, T.; Kimura, S.; Kashiwagi, T.; Hagiwara, M.; Kindo, K.; Kaizaki, S.; Kawata, S. Construction of a Novel Topological Frustrated System: A Frustrated Metal Cluster in a Helical Space. Chem. - Eur. J. 2010, 16 (36), $11139-11144$

(12) Romain, S.; Rich, J.; Sens, C.; Stoll, T.; Benet-Buchholz, J.; Llobet, A.; Rodriguez, M.; Romero, I.; Clerac, R.; Mathoniere, C.; Duboc, C.; Deronzier, A.; Collomb, M.-N. Multireversible Redox Processes in Pentanuclear Bis(Triple-Helical) Manganese Complexes Featuring an Oxo-Centered triangular $\left\{\mathrm{Mn}^{\mathrm{II} 2} \mathrm{Mn}^{\mathrm{III}}\left(\mu_{3}-\mathrm{O}\right)\right\}^{\text {s+ }}$ or $\left\{\mathrm{Mn}^{\mathrm{II}} \mathrm{Mn}_{2}{ }_{2}\left(\mu_{3}-\mathrm{O}\right)\right\}^{6+}$ Core Wrapped by Two $\left\{\mathrm{Mn}_{2}{ }_{2}(\mathrm{bpp})_{3}\right\}^{-}$. Inorg. Chem. 2011, 50 (17), 8427-8436.

(13) Hou, J. Z.; Li, M.; Li, Z.; Zhan, S. Z.; Huang, X. C.; Li, D. Supramolecular helix-to-helix induction: A 3D anionic framework containing double-helical strands templated by cationic triplestranded cluster helicates. Angew. Chem., Int. Ed. 2008, 47 (9), 1711-1714.

(14) Bao, X.; Leng, J. D.; Meng, Z. S.; Lin, Z. J.; Tong, M. L.; Nihei, M.; Oshio, H. Tuning the Spin States of Two Apical Iron(II) Ions in the Trigonal-Bipyramidal $\left[\left\{\mathrm{Fe}^{\mathrm{II}}(\mu \text {-bpt })_{3}\right\}_{2} \mathrm{Fe}_{3}{ }^{\mathrm{II}}\left(\mu_{3}-\mathrm{O}\right)\right]^{2+}$ Cations Through the Choice of Anions. Chem. - Eur. J. 2010, 16 (21), 6169-6174.

(15) Fan, K.-H.; Huang, Q.; Fang, X.-Y.; Zhu, L.-W.; Yan, Z. Tuning the Spin States of Two Apical Iron(II) Ions in a Pentanuclear Iron(II) Cluster Helicate through the Choice of Anions. Crystals 2018, 8 (3), 119.

(16) Yan, Z.; Liu, W.; Peng, Y.-Y.; Chen, Y.-C.; Li, Q.-W.; Ni, Z.-P.; Tong, M.-L. Spin-Crossover Phenomenon in a Pentanuclear Iron(II) Cluster Helicate. Inorg. Chem. 2016, 55 (10), 4891-4896.

(17) Gouré, E.; Gerey, B.; Clémancey, M.; Pécaut, J.; Molton, F.; Latour, J.-M.; Blondin, G.; Collomb, M.-N. Intramolecular Electron 
Transfers Thwart Bistability in a Pentanuclear Iron Complex. Inorg. Chem. 2016, 55 (18), 9178-9186.

(18) Krewald, V.; Pantazis, D. A. Understanding and tuning the properties of redox-accumulating manganese helicates. Dalton Trans. 2016, 45 (47), 18900-18908.

(19) Okamura, M.; Kondo, M.; Kuga, R.; Kurashige, Y.; Yanai, T.; Hayami, S.; Praneeth, V. K. K.; Yoshida, M.; Yoneda, K.; Kawata, S.; Masaoka, S. A pentanuclear iron catalyst designed for water oxidation. Nature 2016, 530 (7591), 465-468.

(20) Praneeth, V. K. K.; Kondo, M.; Okamura, M.; Akai, T.; Izu, H.; Masaoka, S. Pentanuclear iron catalysts for water oxidation: substituents provide two routes to control onset potentials. Chem. Sci. 2019, 10 (17), 4628-4639.

(21) Liao, R.-Z.; Masaoka, S.; Siegbahn, P. E. M. Metal Oxidation States for the $\mathrm{O}-\mathrm{O}$ Bond Formation in the Water Oxidation Catalyzed by a Pentanuclear Iron Complex. ACS Catal. 2018, 8 (12), 11671-11678.

(22) Fukuzumi, S.; Mandal, S.; Mase, K.; Ohkubo, K.; Park, H.; Benet-Buchholz, J.; Nam, W.; Llobet, A. Catalytic Four-Electron Reduction of $\mathrm{O}_{2}$ via Rate-Determining Proton-Coupled Electron Transfer to a Dinuclear Cobalt-mu-1,2-peroxo Complex. J. Am. Chem. Soc. 2012, 134 (24), 9906-9909.

(23) Mandal, S.; Shikano, S.; Yamada, Y.; Lee, Y.-M.; Nam, W.; Llobet, A.; Fukuzumi, S. Protonation Equilibrium and Hydrogen Production by a Dinuclear Cobalt-Hydride Complex Reduced by Cobaltocene with Trifluoroacetic Acid. J. Am. Chem. Soc. 2013, 135 (41), 15294-15297.

(24) Gimbert-Surinach, C.; Moonshiram, D.; Francas, L.; Planas, N.; Bernales, V.; Bozoglian, F.; Guda, A.; Mognon, L.; Lopez, I.; Hoque, M. A.; Gagliardi, L.; Cramer, C. J.; Llobet, A. Structural and Spectroscopic Characterization of Reaction Intermediates Involved in a Dinuclear Co-Hbpp Water Oxidation Catalyst. J. Am. Chem. Soc. 2016, 138 (47), 15291-15294.

(25) Mognon, L.; Mandal, S.; Castillo, C. E.; Fortage, J.; Molton, F.; Aromi, G.; Benet-Buchhlolz, J.; Collomb, M.-N.; Llobet, A. Synthesis, structure, spectroscopy and reactivity of new heterotrinuclear water oxidation catalysts. Chem. Sci. 2016, 7 (5), 3304-3312.

(26) Akai, T.; Kondo, M.; Lee, S. K.; Izu, H.; Enomoto, T.; Okamura, M.; Saga, Y.; Masaoka, S. Effect of metal ion substitution on the catalytic activity of a pentanuclear metal complex. Dalton Trans. 2020, 49 (5), 1384-1387.

(27) Shi, Y.; Arif, A. M.; Ernst, R. D. Structural Studies of the Hexakis(pyridazine)cobalt(II) and Hexakis(pyridazine)ruthenium(II) Ions as their Hexafluorophosphate and Tetraphenylborate Salts. J. Chem. Crystallogr. 2013, 43 (7), 360-364.

(28) Reynolds, R. A.; Yu, W. O.; Dunham, W. R.; Coucouvanis, D. Synthesis and characterization of a new class of $\mu_{3}$-OH-bridged trimers that contain octahedrally coordinated divalent metal ions bridged by three acetate ligands and a unique catecholate ligand. Solid state molecular structures of the $\left[(\mathrm{py})_{5} \mathrm{M}_{3}{ }^{\mathrm{II}}(\mathrm{OAc})_{3}\left(\mu_{3}-\mathrm{OH}\right)((\mathrm{cat})]\right.$ complexes $(\mathrm{M}=\mathrm{Mn}(\mathrm{II}), \mathrm{Fe}(\mathrm{II}), \mathrm{Co}(\mathrm{II}), \mathrm{Ni}(\mathrm{II}))$. Inorg. Chem. 1996, 35 (10), 2721-2722.

(29) Holmberg, R. J.; Kay, M.; Korobkov, I.; Kadantsev, E.; Boyd, P. G.; Aharen, T.; Desgreniers, S.; Woo, T. K.; Murugesu, M. An unprecedented $\mathrm{Co}^{\mathrm{II}}$ cuboctahedron as the secondary building unit in a Co-based metal-organic framework. Chem. Commun. 2014, 50 (40), $5333-5335$

(30) Kostakis, G. E.; Perlepes, S. P.; Blatov, V. A.; Proserpio, D. M.; Powell, A. K. High-nuclearity cobalt coordination clusters: Synthetic, topological and magnetic aspects. Coord. Chem. Rev. 2012, 256 (11), $1246-1278$.

(31) Sumner, C. E. Interconversion of dinuclear and oxo-centered trinuclear cobaltic acetates. Inorg. Chem. 1988, 27 (8), 1320-1327.

(32) Yoshida, J.; Kondo, S.; Yuge, H. A synthetic strategy for a new series of oxo-centered tricobalt complexes with mixed bridging ligands of acetate and pyrazolate anions. Dalton Trans. 2013, 42 (7), 24062413.

(33) Beattie, J. K.; Klepetko, J. A.; Masters, A. F.; Turner, P. The chemistry of cobalt acetate. VIII. New members of the family of oxo- centred trimers, $\left[\mathrm{Co}_{3}\left(\mu_{3}-\mathrm{O}\right)\left(\mu-\mathrm{O}_{2} \mathrm{CCH}_{3}\right)_{5-\mathrm{p}}(\mu-\mathrm{OR})_{\mathrm{p}} \mathrm{L}_{5}\right]^{2+}(\mathrm{R}=\mathrm{H}$, alkyl, $\mathrm{L}=$ ligand, $\mathrm{p}=0-4)$. The preparation and characterisation of the trimeric tetrakis $(\mu$-acetato $)$-( $\mu$-hydroxo $)-\mu_{3}$-oxo-pentakis(pyridine)-tri-cobalt(III) hexafluorophosphate, $\left[\mathrm{Co}_{3}\left(\mu_{3}-\mathrm{O}\right)(\mu\right.$ $\left.\left.\mathrm{O}_{2} \mathrm{CCH}_{3}\right)_{4}(\mu-\mathrm{OH})\left(\mathrm{C}_{5} \mathrm{H}_{5} \mathrm{~N}\right)_{5}\right]\left[\mathrm{PF}_{6}\right]_{2}$, and the preparation and crystal structure of the trimeric tris $(\mu$-acetato $)$ - $(\mu$-hydroxo $)-(\mu$-methoxo $)-\mu_{3}$ oxo-pentakis(pyridine)-tri-cobalt(III) hexafluorophosphate-methanolwater solvate $\left[\mathrm{Co}_{3}\left(\mu_{3}-\mathrm{O}\right)\left(\mu-\mathrm{O}_{2} \mathrm{CCH}_{3}\right)_{3}(\mu-\mathrm{OH})\left(\mu-\mathrm{OCH}_{3}\right)\right.$ $\left.\left(\mathrm{C}_{5} \mathrm{H}_{5} \mathrm{~N}\right)_{5}\right]\left[\mathrm{PF}_{6}\right]_{2} \cdot \mathrm{CH}_{3} \mathrm{OH} \cdot 0.25 \mathrm{H}_{2} \mathrm{O}$. Polyhedron 2003, 22 (7), 947965

(34) Zhuang, W.; Sun, H.; Xu, H.; Wang, Z.; Gao, S.; Jin, L. Reversible de-/resolvation and accompanied magnetism modulation in a framework of topologically ferrimagnetic $\left[\mathrm{Co}_{3}\left(\mu_{3}-\mathrm{OH}\right)_{2}\right]_{\mathrm{n}}$ chains linked by a V-shaped ligand 4,4'-dicarboxybiphenyl sulfone. Chem. Commun. 2010, 46 (24), 4339-4341.

(35) Han, S.-D.; Song, W.-C.; Zhao, J.-P.; Yang, Q.; Liu, S.-J.; Li, Y.; $\mathrm{Bu}, \mathrm{X}$.-H. Synthesis and ferrimagnetic properties of an unprecedented polynuclear cobalt complex composed of $\left[\mathrm{Co}_{24}\right]$ macrocycles. Chem. Commun. 2013, 49 (9), 871-873.

(36) Chen, Q.; Lin, J.-B.; Xue, W.; Zeng, M.-H.; Chen, X.-M. A Porous Coordination Polymer Assembled from 8-Connected $\left\{\mathrm{Co}_{3}{ }_{3}(\mathrm{OH})\right\}$ Clusters and Isonicotinate: Multiple Active Metal Sites, Apical Ligand Substitution, $\mathrm{H}_{2}$ Adsorption, and Magnetism. Inorg. Chem. 2011, 50 (6), 2321-2328.

(37) Varma, S.; Castillo, C. E.; Stoll, T.; Fortage, J.; Blackman, A. G.; Molton, F.; Deronzier, A.; Collomb, M.-N. Efficient Photocatalytic Hydrogen Production in Water Using a Cobalt(III) TetraazaMacrocyclic Catalyst: Electrochemical Generation of the Low-Valent $\mathrm{Co}(\mathrm{I})$ Species and its Reactivity Toward Proton Reduction. Phys. Chem. Chem. Phys. 2013, 15 (40), 17544-17552.

(38) Lo, W. K. C.; Castillo, C. E.; Gueret, R.; Fortage, J.; Rebarz, M.; Sliwa, M.; Thomas, F.; McAdam, C. J.; Jameson, G. B.; McMorran, D. A.; Crowley, J. D.; Collomb, M.-N.; Blackman, A. G. Synthesis, Characterization, and Photocatalytic $\mathrm{H}_{2}$-Evolving Activity of a Family of $\left[\mathrm{Co}\left(\mathrm{N}_{4} \mathrm{Py}\right)(\mathrm{X})\right]^{\mathrm{n}+}$ Complexes in Aqueous Solution. Inorg. Chem. 2016, 55 (9), 4564-4581.

(39) Gueret, R.; Castillo, C. E.; Rebarz, M.; Thomas, F.; Sliwa, M.; Chauvin, J.; Dautreppe, B.; Pécaut, J.; Fortage, J.; Collomb, M.-N. Cobalt(II) Pentaaza-Macrocyclic Schiff Base Complex as Catalyst for Light-Driven Hydrogen Evolution in Water: Electrochemical Generation and Theoretical Investigation of the One-Electron Reduced Species. Inorg. Chem. 2019, 58 (14), 9043-9056.

(40) Casabó, J.; Pons, J.; Siddiqi, K. S.; Teixidor, F.; Molins, E.; Miravitlles, C. Notes. A planar, binucleating, pyrazole derivative ligand. Crystal structure of bis $[\mu-3,5$-bis(2-pyridyl)pyrazolatoN1N:N2N"]-bis[dimethanolnickel(II)] dichloride dihydrate. $J$. Chem. Soc., Dalton Trans. 1989, No. 7, 1401-1403.

(41) Ishikawa, R.; Fuyuhiro, A.; Hayami, S.; Inoue, K.; Kawata, S. Intriguing assembled structure and properties of a novel dinuclear nickel(II) complex with an axially coordinated azide and methanol. $J$. Mol. Struct. 2008, 892 (1-3), 220-224.

(42) Du, M.; Chen, S.-T.; Guo, Y.-M.; Bu, X.-H.; Ribas, J. Synthesis, crystal structure, spectroscopy and magnetic properties of a dinuclear $\mathrm{Cu}^{\mathrm{II}}$ complex with 3,5-bis(2-pyridyl)pyrazole bridging ligand. J. Mol. Struct. 2005, 737 (1), 17-21.

(43) Pons, J.; López, X.; Casabó, J.; Teixidor, F.; Caubet, A.; Rius, J.; Miravitlles, C. Copper complexes with a pyrazole derivative ligand. Crystal structure of tetrakis $\{[(3,5$-bis(pyridin-2-yl)pyrazolate)(aqua)copper(II)] nitrate monohydrate\}. Inorg. Chim. Acta 1992, 195 (1), 61-66.

(44) Munakata, M.; Wu, L. P.; Yamamoto, M.; KurodaSowa, T.; Maekawa, M.; Kawata, S.; Kitagawa, S. Co-ordinative versatility of 3,5bis(2-pyridyl)pyrazole in silver and copper compounds. J. Chem. Soc., Dalton Trans. 1995, No. 24, 4099-4106.

(45) Suemura, N.; Ohama, M.; Kaizaki, S. Direct observation of light induced spin transitions in new 3,5-bis(2-pyridyl)pyrazolato bridged thiocyanato diiron(II) complexes by monitoring variable temperature laser Raman spectra. Chem. Commun. 2001, No. 17, 1538-1539. 
(46) Nakano, K.; Suemura, N.; Kawata, S.; Fuyuhiro, A.; Yagi, T.; Nasu, S.; Morimoto, S.; Kaizaki, S. Magnetic behavior and Mossbauer spectra of spin-crossover pyrazolate bridged dinuclear diiron(II) complexes: X-ray structures of high-spin and low-spin $\left[\left\{\mathrm{Fe}\left(\mathrm{NCBH}_{3}\right)\right.\right.$ (py) $\left.\}_{2}(\mu \text {-bpypz })_{2}\right]$. Dalton Trans. 2004, No. 7, 982-988.

(47) Nakano, K.; Kawata, S.; Yoneda, K.; Fuyuhiro, A.; Yagi, T.; Nasu, S.; Morimoto, S.; Kaizaki, S. Direct two-step spin-crossover through [HS-HS]center dot center dot center $\operatorname{dot}[\mathrm{LS}-\mathrm{LS}]$ at the plateau in dinuclear diiron(II) complex $\left[\left\{\mathrm{Fe}\left(\mathrm{NCBH}_{3}\right)(4 \mathrm{phpy})\right\}_{2}(\mu\right.$ bpypz $)_{2}$ ]. Chem. Commun. 2004, No. 24, 2892-2893.

(48) Schneider, C. J.; Cashion, J. D.; Moubaraki, B.; Neville, S. M.; Batten, S. R.; Turner, D. R.; Murray, K. S. The magnetic and structural elucidation of 3,5-bis(2-pyridyl)-1,2,4-triazolate-bridged dinuclear iron(II) spin crossover compounds. Polyhedron 2007, 26 (9), 1764-1772.

(49) Yoneda, K.; Nakano, K.; Fujioka, J.; Yamada, K.; Suzuki, T.; Fuyuhiro, A.; Kawata, S.; Kaizaki, S. Synthesis, structure and magnetic properties of pyrazolate-bridged dinuclear complexes $[\{\mathrm{M}(\mathrm{NCS})(4-$ Phpy $\left.\}_{2}(\mu \text {-bpypz })_{2}\right]\left(\mathrm{M}=\mathrm{Co}^{2+}\right.$ and $\left.\mathrm{Fe}^{2+}\right)$. Polyhedron 2005, 24 (1617), 2437-2442.

(50) Yoneda, K.; Adachi, K.; Hayami, S.; Maeda, Y.; Katada, M.; Fuyuhiro, A.; Kawata, S.; Kaizaki, S. A steep one-step [HS-HS] to [LS-LS] spin transition in a 4,4'-bipyridine linked one-dimensional coordination polymer constructed from a pyrazolato bridged $\mathrm{Fe}$ (II) dimer. Chem. Commun. 2006, No. 1, 45-47.

(51) Ishikawa, R.; Ueno, S.; Nifuku, S.; Horii, Y.; Iguchi, H.; Miyazaki, Y.; Nakano, M.; Hayami, S.; Kumagai, S.; Katoh, K.; Li, Z.Y.; Yamashita, M.; Kawata, S. Simultaneous Spin-Crossover Transition and Conductivity Switching in a Dinuclear Iron(II) Coordination Compound Based on 7,7',8,8'-Tetracyano-p-quinodimethane. Chem. - Eur. J. 2020, 26 (6), 1278-1285.

(52) Tong, J.; Jia, L.-M.; Shang, P.; Yu, S.-Y. Controlled Synthesis of Supramolecular Architectures of Homo- and Heterometallic Complexes by Programmable Self-Assembly. Cryst. Growth Des. 2019, 19 (1), 30-39.

(53) Washizaki, T.; Ishikawa, R.; Yoneda, K.; Kitagawa, S.; Kaizaki, S.; Fuyuhiro, A.; Kawata, S. Reversible solid-state hydration and dehydration process involving anion transfer in a self-assembled $\mathrm{Cu}_{2}$ system. RSC Adv. 2012, 2 (32), 12169-12172.

(54) Dinh Nguyen, M. T.; Charlot, M.-F.; Aukauloo, A. Structural, Electronic, and Theoretical Description of a Series of Cobalt Clathrochelate Complexes in the $\mathrm{Co}(\mathrm{III}), \mathrm{Co}(\mathrm{II})$ and $\mathrm{Co}(\mathrm{I})$ Oxidation States. J. Phys. Chem. A 2011, 115 (5), 911-922.

(55) Pietrzyk, P.; Srebro, M.; Radoń, M.; Sojka, Z.; Michalak, A. Spin Ground State and Magnetic Properties of Cobalt(II): Relativistic DFT Calculations Guided by EPR Measurements of Bis(2,4acetylacetonate)cobalt(II)-Based Complexes. J. Phys. Chem. A 2011, 115 (11), 2316-2324.

(56) Mabbs, F. E.; Machin, D. J. Magnetism and Transition Metals Complexes; Chapman and Hall Ltd.: London, 1973.

(57) Carlin, R. L. Magnetochemistry; Springer-Verlag: Berlin, 1986. 


\section{Seven reversible redox processes in a self-assembled cobalt pentanuclear bis(triple-stranded helicate): structural, spectroscopic and magnetic characterizations in the $\mathrm{Co}^{\mathrm{I}} \mathrm{Co}^{\mathrm{II}_{4}}, \mathrm{Co}^{\mathrm{II}_{5}}$ and $\mathrm{Co}_{3}{ }_{3} \mathrm{Co}{ }^{\mathrm{III}}$ redox states}

Eric Gouré, ${ }^{\dagger}$ Bertrand Gerey, ${ }^{\dagger}$ Florian Molton, ${ }^{\dagger}$ Jacques Pécaut, ${ }^{\ddagger}$ Rodolphe Clérac, ${ }^{\S}$ Fabrice Thomas, ${ }^{\dagger}$ Jérôme Fortage $^{\dagger}$ and Marie-Noëlle Collomb*, ${ }^{\dagger}$

$\dagger$ Univ. Grenoble Alpes, CNRS, DCM, 38000 Grenoble, France

${ }^{\ddagger}$ Univ. Grenoble Alpes, CEA, CNRS, IRIG, SyMMES, 38000 Grenoble, France

${ }^{\S}$ Univ. Bordeaux, CNRS, Centre de Recherche Paul Pascal, UMR 5031, F-33600 Pessac, France

*E-mail: marie-noelle.collomb@univ-grenoble-alpes.fr

\section{Table of Contents}

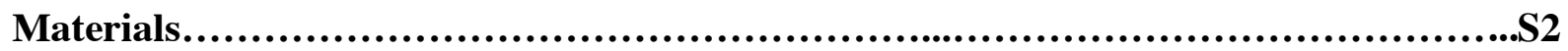

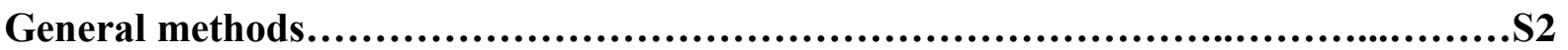

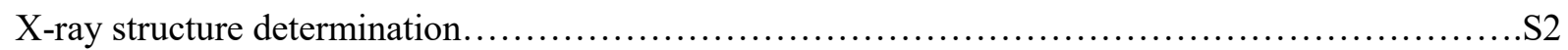

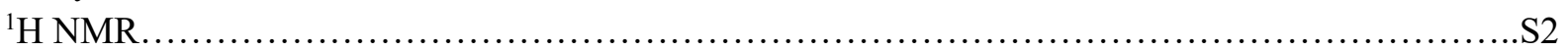

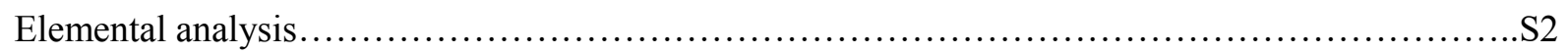

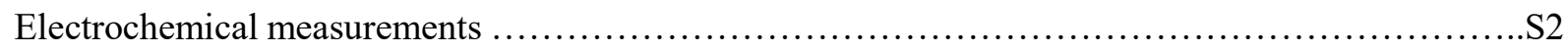

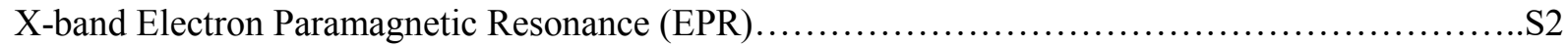

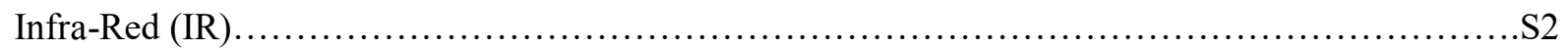

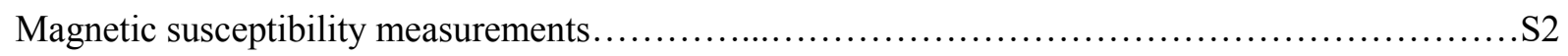

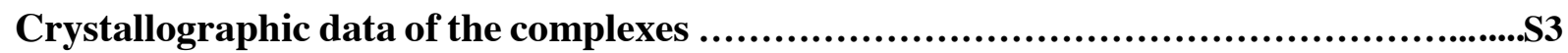

Table S1. Crystallographic refinement data for the structure of $\mathbf{1}^{3+}, \mathbf{1}^{5+}$, and $\mathbf{1}^{2+} \ldots \ldots \ldots \ldots \ldots \ldots . . .63$

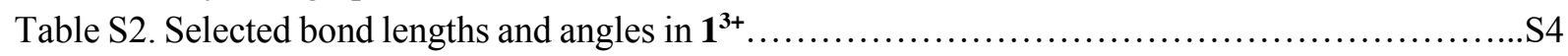

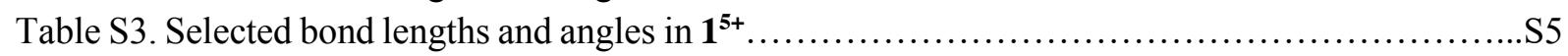

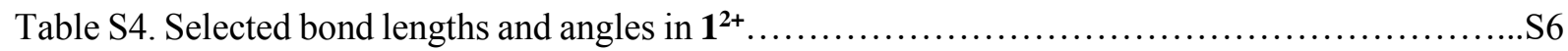

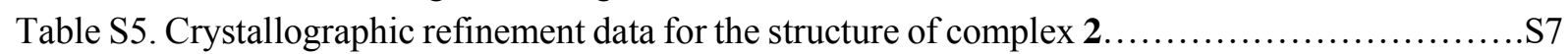

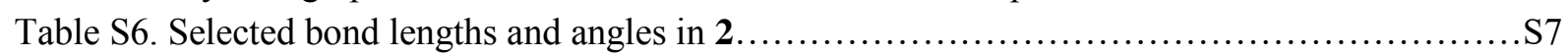

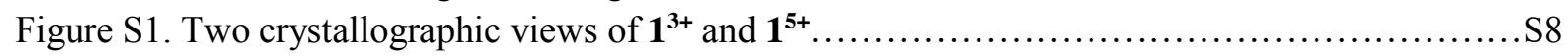

Electrochemical data and visible absorption spectra of the complexes...................S9

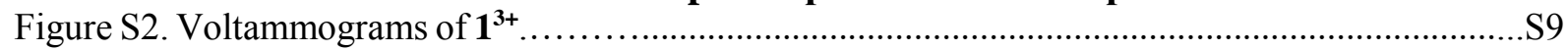

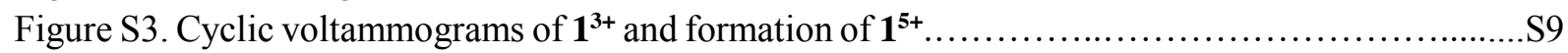

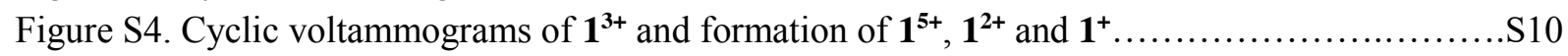

Figure S5. Vis. Abs. spectra changes during the electrochemical formation of $\mathbf{1}^{5+}, \mathbf{1}^{\mathbf{2 +}}$ and $\mathbf{1}^{+} \ldots \ldots \ldots$. S1

Magnetic properties of the complexes............................................S12

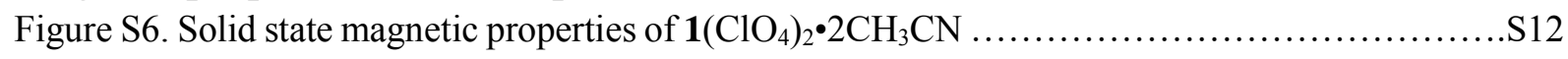

Figure S7. Solid state magnetic properties of $\mathbf{1}\left(\mathrm{BF}_{4}\right)_{3} \cdot 3.75 \mathrm{CH}_{3} \mathrm{CN} \cdot 0.33 \mathrm{H}_{2} \mathrm{O} \ldots \ldots \ldots \ldots \ldots \ldots \ldots \ldots . . . . . . . . . . . .3$

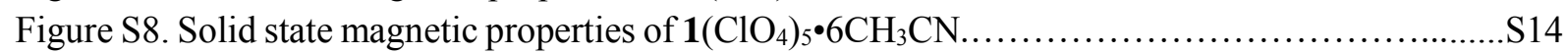

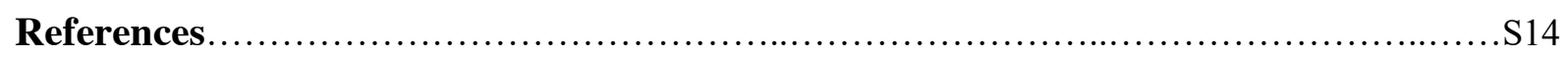




\section{Materials}

All solvents and reagents were laboratory reagent grade or better and used as received. Acetonitrile $\left(\mathrm{CH}_{3} \mathrm{CN}\right.$, Fisher, HPLC grade), and tetra- $n$-butyl-ammonium perchlorate $\left(\left[\mathrm{Bu}_{4} \mathrm{~N}\right] \mathrm{ClO}_{4}\right.$, Fluka) for electrochemical measurements were stored under an argon atmosphere in a dry-glove box. The triethylamine $\left(\mathrm{Et}_{3} \mathrm{~N} ; 99.5 \%\right.$, Alfa Aesar), tetra- $n$-butylammonium hydroxide $\left[\mathrm{Bu}_{4} \mathrm{~N}\right] \mathrm{OH}(1 \mathrm{M}$ in methanol), Alfa Aesar) and the ligand 3,5-bis(pyridin-2-yl)-pyrazole (Hbpp) (98\%, TCI) were used as received.

\section{General methods}

$X$-ray structure determination. Single-crystal X-ray diffraction data were taken using an OxfordDiffraction Xcalibur S kappa geometry diffractometer (Mo-K $\alpha$ radiation, graphite monochromator, $\lambda=$ $0.71073 \AA$ ). To prevent evaporation of co-crystallized solvent molecules the crystals were coated with light hydrocarbon oil and the data were collected at $150 \mathrm{~K}$. The cell parameters were obtained with intensities detected on three batches of 5 frames. The crystal-detector distance was $4.5 \mathrm{~cm}$. The number of settings and frames has been established taking in consideration the Laue symmetry of the cell by CrysAlisPro Oxford-diffraction software. Unique intensities detected on all frames using the Oxforddiffraction Red program were used to refine the values of the cell parameters. The substantial redundancy in data allows empirical absorption corrections to be applied using with the ABSPACK Oxford-diffraction program. Space groups were determined from systematic absences, and they were confirmed by the successful solution of the structure. The structures were solved by direct methods using the SHELXT in Olex 2 software environment. All non-hydrogen atoms were found by difference Fourier syntheses and refined on $F^{2}$ using ShelXL. All hydrogen atoms were fixed in ideal position and refine with a riding model. Full crystallographic details are given in Tables S1 and S5.

The elemental analyses were performed with the ICMG Chemistry Nanobio Platform, Grenoble.

Electrochemical measurements were made at room temperature under an argon atmosphere in a dryglovebox. Cyclic voltammetry and controlled potential electrolysis experiments were performed by using an EG\&G model 173 potentiostat/galvanostat equipped with a PAR model universal programmer and a PAR model 179 digital coulometer. A standard three-electrode electrochemical cell was used. Potentials were referred to an $\mathrm{Ag} / 0.01 \mathrm{M} \mathrm{AgNO}_{3}$ reference electrode in $\mathrm{CH}_{3} \mathrm{CN}+0.1 \mathrm{M}\left[\mathrm{Bu}_{4} \mathrm{~N}_{\mathrm{ClO}} \mathrm{Cl}_{4}\right.$. With this reference electrode, the ferrocene/ferrocenium reversible wave is located at $E_{1 / 2}=100 \mathrm{mV}$. The working electrodes, polished with $2-\mu \mathrm{m}$ diamond paste (Mecaprex Presi), were a platinum disk (3 or $5 \mathrm{~mm}$ in diameter) and vitreous carbon disk ( $3 \mathrm{~mm}$ in diameter) for cyclic voltammetry $\left(E \mathrm{p}_{\mathrm{a}}\right.$, anodic peak potential; $E \mathrm{p}_{\mathrm{c}}$, cathodic peak potential; $\left.E_{1 / 2}=\left(E \mathrm{p}_{\mathrm{a}}+E \mathrm{p}_{\mathrm{c}}\right) / 2 ; \Delta E \mathrm{p}=E \mathrm{p}_{\mathrm{a}}-E \mathrm{p}_{\mathrm{c}}\right)$. For rotating disk electrode (RDE) experiments, a carbon disk ( $2 \mathrm{~mm}$ in diameter) was used. Exhaustive electrolyses were carried out on reticulated vitreous carbon electrode 45 PPI (the electrosynthesis Co. Inc.; $1 \mathrm{~cm}^{3}$ ). The auxiliary electrode was a $\mathrm{Pt}$ wire in $\mathrm{CH}_{3} \mathrm{CN}+0.1 \mathrm{M}\left[\mathrm{Bu}_{4} \mathrm{~N}\right] \mathrm{ClO}_{4}$. Progress of the electrolysis was followed by the change in UV-Vis spectra with a MCS 501 UV-NIR (Carl Zeiss) spectrophotometer equipped with an automatic shutter. The light sources are halogen (CLH $50020 \mathrm{~W}$ ) and deuterium lamps (CLD 500) with optic fibers (041.002-UV SN 012105), and a $1 \mathrm{~mm}$ path-length cell.

$X$-band Electron Paramagnetic Resonance (EPR) spectra were recorded on a Bruker EMX, equipped with the Bruker ER-4102 ST cavity at 100K and a Bruker ER-4116 DM cavity at 13K.

Infra-Red spectra $(I R)$ were recorded on were recorded neat on Thermo Scientific Nicolet iS10 FT-IR spectrometer using an ATR (Attenuated Total Reflexion) module.

Magnetic susceptibility measurements were performed on a Quantum Design SQUID MPMS-XL magnetometer housed at the Centre de Recherche Paul Pascal at temperatures between 1.8 and $400 \mathrm{~K}$ and $d c$ magnetic fields ranging from -7 to $+7 \mathrm{~T}$. The measurements were carried out on polycrystalline 
samples $\left(15.50,13.87\right.$ and $14.30 \mathrm{mg}$ for $\mathbf{1}\left(\mathrm{ClO}_{4}\right)_{2} \cdot 2 \mathrm{CH}_{3} \mathrm{CN}, \mathbf{1}\left(\mathrm{BF}_{4}\right)_{3} \cdot 3.75 \mathrm{CH}_{3} \mathrm{CN} \cdot 0.33 \mathrm{H}_{2} \mathrm{O}$ and $\mathbf{1}\left(\mathrm{ClO}_{4}\right)_{5} \cdot 6 \mathrm{CH}_{3} \mathrm{CN}$ respectively) suspended in mineral oil (typically $5-12 \mathrm{mg}$ ) and introduced in a sealed polyethylene bag (typically $3 \times 0.5 \times 0.02 \mathrm{~cm}$ and $20-40 \mathrm{mg}$ ). Prior to the experiments, the fielddependent magnetization was measured at $100 \mathrm{~K}$ on each sample in order to detect the presence of any bulk ferromagnetic impurities. In fact, paramagnetic or diamagnetic materials should exhibit a perfectly linear dependence of the magnetization that extrapolates to zero at zero $d c$ field; the samples appeared to be free of any ferromagnetic impurities. The magnetic susceptibilities were corrected for the sample holder, the mineral oil and the intrinsic diamagnetic contributions. The $a c$ magnetic susceptibility measurements were performed in an oscillating $a c$ field of 3 Oe with frequencies between 1 and 1500 $\mathrm{Hz}$ in zero dc-field. The ac measurements revealed the absence of an imaginary component of the ac susceptibility and thus the absence of Single-Molecule Magnet properties.

\section{Crystallographic data of the complexes}

Table S1. Crystallographic refinement data for the structure of $\left[\left\{\mathrm{Co}^{\mathrm{II}}(\mu-\mathrm{bpp})_{3}\right\}_{2} \mathrm{Co}_{3}{ }_{3}\left(\mu_{3}-\right.\right.$ $\mathrm{OH})]\left(\mathrm{BF}_{4}\right)_{3} \cdot 3.75 \mathrm{CH}_{3} \mathrm{CN} \bullet 0.33 \mathrm{H}_{2} \mathrm{O} \quad\left(1\left(\mathrm{BF}_{4}\right)_{3} \cdot 3.75 \mathrm{CH}_{3} \mathrm{CN} \bullet 0.33 \mathrm{H}_{2} \mathrm{O}\right), \quad\left[\left\{\mathrm{Co}^{\mathrm{III}}(\mu-\mathrm{bpp})_{3}\right\}_{2} \mathrm{Co}_{3}{ }_{3}\left(\mu_{3}-\right.\right.$ $\mathrm{OH})]\left(\mathrm{ClO}_{4}\right)_{5} \bullet 6 \mathrm{CH}_{3} \mathrm{CN} \quad\left(\mathbf{1}\left(\mathrm{ClO}_{4}\right)_{5} \cdot 6 \mathrm{CH}_{3} \mathrm{CN}\right)$ and $\left[\left\{\mathrm{Co}^{\mathrm{II}}(\mu-\mathrm{bpp})_{3}\right\}_{2} \mathrm{Co}^{\mathrm{I}} \mathrm{Co}_{2}{ }_{2}(\mu-\mathrm{OH})\right]\left(\mathrm{ClO}_{4}\right)_{2} \bullet 2 \mathrm{CH}_{3} \mathrm{CN}$ $\left(\mathbf{1}\left(\mathrm{ClO}_{4}\right)_{2} \cdot 2 \mathrm{CH}_{3} \mathrm{CN}\right)$.

\begin{tabular}{|c|c|c|c|}
\hline & $\mathbf{1}\left(\mathrm{BF}_{4}\right)_{3} \cdot 3.75 \mathrm{CH}_{3} \mathrm{CN} \bullet 0.33 \mathrm{H}_{2}$ & $\mathbf{1}\left(\mathrm{ClO}_{4}\right)_{5} \cdot 6 \mathrm{CH}_{3} \mathrm{CN}$ & $\mathbf{1}\left(\mathrm{ClO}_{4}\right)_{2} \cdot 2 \mathrm{CH}_{3} \mathrm{CN}$ \\
\hline CDCD reference & 1956211 & 1956212 & 1956213 \\
\hline Empirical formula & $\mathrm{C}_{85.50} \mathrm{H}_{66.92} \mathrm{~B}_{3} \mathrm{Co}_{5} \mathrm{~F}_{12} \mathrm{~N}_{27.75} \mathrm{O}_{1.33}$ & $\mathrm{C}_{90} \mathrm{H}_{73} \mathrm{Cl}_{5} \mathrm{Co}_{5} \mathrm{~N}_{30} \mathrm{O}_{21}$ & $\mathrm{C}_{82} \mathrm{H}_{61} \mathrm{Cl}_{2} \mathrm{Co}_{5} \mathrm{~N}_{26} \mathrm{O}_{9}$ \\
\hline Formula weight & 2059.49 & 2382.68 & 1920.11 \\
\hline Colour, shape & brown, block & brown, block & green, block \\
\hline Crystal size, $\mathrm{mm}$ & $0.929 \times 0.421 \times 0.282$ & $0.497 \times 0.193 \times 0.146$ & $0.141 \times 0.134 \times 0.090$ \\
\hline Crystal system & Monoclinic & Monoclinic & Monoclinic \\
\hline Space group & $P 2{ }_{1} / n$ & $C c$ & $C 2 / c$ \\
\hline$a, \AA$ & $15.2684(11)$ & $29.5763(19)$ & $19.113(2)$ \\
\hline$b, \AA$ & $22.4500(13)$ & $15.6790(4)$ & $24.8187(19)$ \\
\hline$c, \AA$ & $26.7450(19)$ & $29.230(2)$ & $16.8047(14)$ \\
\hline$\alpha$, deg. & 90 & 90 & 90 \\
\hline$\beta$, deg. & $102.609(7)$ & $130.768(11)$ & $99.162(10)$ \\
\hline$\gamma$, deg. & 90 & 90 & 90 \\
\hline$V, \AA^{3}$ & $8946.4(11)$ & $10265.9(16)$ & $7869.6(13)$ \\
\hline$Z$ & 4 & 4 & 4 \\
\hline$T, \mathrm{~K}$ & $150(2)$ & $150(2)$ & $150(2)$ \\
\hline$\rho$ (calc), $\mathrm{Mg} / \mathrm{m}^{3}$ & 1.529 & 1.542 & 1.621 \\
\hline$\beta \mathrm{mm}^{-1}$ & 0.997 & 1.005 & 1.179 \\
\hline$\theta$ range, deg. & 2.979 to 30.508 & 3.013 to 26.372 & 2.049 to 26.366 \\
\hline rflen coll/obsv (Rint) & $55465 / 27049(0.0327)$ & $45662 / 20130(0.0402)$ & $16215 / 8015(0.0977)$ \\
\hline GooF & 1.026 & 1.060 & 1.052 \\
\hline$R 1$ & 0.0566 & 0.0528 & 0.0820 \\
\hline$w R 2$ & 0.1380 & 0.1398 & 0.1534 \\
\hline
\end{tabular}


Table S2. Selected bond lengths $(\AA)$ and angles $(\mathrm{deg})$ in $\left[\left\{\mathrm{Co}(\mu-\mathrm{II} p)_{3}\right\}_{2} \mathrm{Co}_{3}{ }_{3}(\mu-\mathrm{OH})\right]\left(\mathrm{BF}_{4}\right)_{3} \cdot 3.75$ $\mathrm{CH}_{3} \mathrm{CN} \bullet 0.33 \mathrm{H}_{2} \mathrm{O}\left(\mathbf{1}\left(\mathrm{BF}_{4}\right)_{3} \bullet 3.75 \mathrm{CH}_{3} \mathrm{CN} \bullet 0.33 \mathrm{H}_{2} \mathrm{O}\right)$ (apical, ap; equatorial, eq).

\begin{tabular}{|c|c|c|c|c|c|c|c|}
\hline \multicolumn{8}{|l|}{ Co ap- $^{N}$ distances } \\
\hline $\mathrm{Co}(4)-\mathrm{N}(42)$ & $2.088(2)$ & \multicolumn{2}{|c|}{$\mathrm{Co}(5)-\mathrm{N}(82)$} & \multicolumn{4}{|l|}{$2.097(2)$} \\
\hline $\mathrm{Co}(4)-\mathrm{N}(3)$ & $2.0948(19)$ & \multicolumn{2}{|c|}{$\mathrm{Co}(5)-\mathrm{N}(102)$} & \multicolumn{2}{|l|}{$2.103(2)$} & & \\
\hline $\mathrm{Co}(4)-\mathrm{N}(22)$ & $2.1026(19)$ & \multicolumn{2}{|c|}{$\mathrm{Co}(5)-\mathrm{N}(62)$} & \multicolumn{2}{|l|}{$2.104(2)$} & & \\
\hline $\mathrm{Co}(4)-\mathrm{N}(21)$ & $2.199(2)$ & \multicolumn{2}{|c|}{ Co(5)-N(61) } & \multicolumn{2}{|l|}{$2.199(2)$} & & \\
\hline $\mathrm{Co}(4)-\mathrm{N}(2)$ & $2.2028(19)$ & \multicolumn{2}{|c|}{$\mathrm{Co}(5)-\mathrm{N}(101)$} & \multicolumn{2}{|l|}{$2.201(2)$} & & \\
\hline $\mathrm{Co}(4)-\mathrm{N}(41)$ & $2.213(2)$ & \multicolumn{2}{|c|}{$\mathrm{Co}(5)-\mathrm{N}(81)$} & \multicolumn{2}{|l|}{$2.205(2)$} & & \\
\hline \multicolumn{8}{|l|}{$\mathrm{Co}_{\mathrm{eq}}-\mathrm{N}, \mathrm{O}$ distances } \\
\hline $\mathrm{Co}(1)-\mathrm{N}(4)$ & $2.0299(18)$ & \multicolumn{2}{|c|}{$\mathrm{Co}(2)-\mathrm{O}(1)$} & $2.0277(14)$ & $\mathrm{Co}(3)-\mathrm{O}(1)$ & \multicolumn{2}{|l|}{$2.0224(14)$} \\
\hline $\mathrm{Co}(1)-\mathrm{N}(63)$ & $2.0377(19)$ & \multicolumn{2}{|c|}{$\mathrm{Co}(2)-\mathrm{N}(103)$} & $2.042(2)$ & $\mathrm{Co}(3)-\mathrm{N}(83)$ & $2.040(2)$ & \\
\hline $\mathrm{Co}(1)-\mathrm{O}(1)$ & $2.0399(14)$ & & $\mathrm{N}(43)$ & $2.048(2)$ & $\mathrm{Co}(3)-\mathrm{N}(23)$ & $2.040(2)$ & \\
\hline $\mathrm{Co}(1)-\mathrm{N}(64)$ & $2.075(2)$ & & $\mathrm{N}(44)$ & $2.066(2)$ & $\mathrm{Co}(3)-\mathrm{N}(84)$ & $2.081(2)$ & \\
\hline $\mathrm{Co}(1)-\mathrm{N}(5)$ & $2.0850(19)$ & & $\mathrm{N}(104)$ & $2.074(2)$ & $\mathrm{Co}(3)-\mathrm{N}(24)$ & $2.082(2)$ & \\
\hline $\mathrm{N}-\mathrm{Co}_{\text {ap}}-\mathrm{N}$ angles & & & & & & $\mathrm{Co}_{\text {eq }}-\mathrm{O}(\mathrm{H})-\mathrm{Co}_{\mathrm{eq}}$ ang & \\
\hline $\mathrm{N}(42)-\mathrm{Co}(4)-\mathrm{N}(3)$ & 97.1 & & $\mathrm{~N}(82)-\mathrm{C}$ & $\mathrm{o}(5)-\mathrm{N}(102)$ & $98.17(8)$ & $\mathrm{Co}(3)-\mathrm{O}(1)-\mathrm{Co}(2)$ & $121.50(7)$ \\
\hline $\mathrm{N}(42)-\mathrm{Co}(4)-\mathrm{N}(22)$ & 96.0 & & $N(82)-C$ & $\mathrm{o}(5)-\mathrm{N}(62)$ & $96.81(8)$ & $\mathrm{Co}(3)-\mathrm{O}(1)-\mathrm{Co}(1)$ & $120.35(7)$ \\
\hline $\mathrm{N}(3)-\mathrm{Co}(4)-\mathrm{N}(22)$ & 95.8 & & $\mathrm{~N}(102)$ & $\mathrm{Co}(5)-\mathrm{N}(62)$ & $97.10(8)$ & $\mathrm{Co}(2)-\mathrm{O}(1)-\mathrm{Co}(1)$ & $118.11(7)$ \\
\hline $\mathrm{N}(42)-\mathrm{Co}(4)-\mathrm{N}(21)$ & 164. & & $\mathrm{~N}(82)-\mathrm{C}$ & $\mathrm{o}(5)-\mathrm{N}(61)$ & $96.68(8)$ & & \\
\hline $\mathrm{N}(3)-\mathrm{Co}(4)-\mathrm{N}(21)$ & 96.8 & & $\mathrm{~N}(102)$ & $\mathrm{Co}(5)-\mathrm{N}(61)$ & $164.27(8)$ & $\mathrm{Co}_{\mathrm{eq}}-\mathrm{O}-\mathrm{H}$ angles & \\
\hline $\mathrm{N}(22)-\mathrm{Co}(4)-\mathrm{N}(21)$ & 76.7 & & $\mathrm{~N}(62)-\mathrm{C}$ & $\mathrm{o}(5)-\mathrm{N}(61)$ & $75.96(8)$ & $\mathrm{Co}(3)-\mathrm{O}(1)-\mathrm{H}(1)$ & 90.7 \\
\hline $\mathrm{N}(42)-\mathrm{Co}(4)-\mathrm{N}(2)$ & 98.1 & & $\mathrm{~N}(82)-\mathrm{C}$ & $\mathrm{o}(5)-\mathrm{N}(101)$ & $165.03(8)$ & $\mathrm{Co}(2)-\mathrm{O}(1)-\mathrm{H}(1)$ & 90.7 \\
\hline $\mathrm{N}(3)-\mathrm{Co}(4)-\mathrm{N}(2)$ & 76.7 & & $\mathrm{~N}(102)$ & $\mathrm{Co}(5)-\mathrm{N}(101)$ & $76.26(8)$ & $\mathrm{Co}(4)-\mathrm{O}(1)-\mathrm{H}(1)$ & 90.7 \\
\hline $\mathrm{N}(22)-\mathrm{Co}(4)-\mathrm{N}(2)$ & 164. & & $N(62)-C$ & $\mathrm{o}(5)-\mathrm{N}(101)$ & $97.67(8)$ & & \\
\hline $\mathrm{N}(21)-\mathrm{Co}(4)-\mathrm{N}(2)$ & 90.7 & & $\mathrm{~N}(61)-\mathrm{C}$ & $\mathrm{o}(5)-\mathrm{N}(101)$ & $90.53(9)$ & & \\
\hline $\mathrm{N}(42)-\mathrm{Co}(4)-\mathrm{N}(41)$ & 76.2 & & $\mathrm{~N}(82)-\mathrm{C}$ & $\mathrm{o}(5)-\mathrm{N}(81)$ & $76.14(8)$ & & \\
\hline $\mathrm{N}(3)-\mathrm{Co}(4)-\mathrm{N}(41)$ & 164. & & $\mathrm{~N}(102)$ & $\mathrm{Co}(5)-\mathrm{N}(81)$ & $97.35(8)$ & & \\
\hline $\mathrm{N}(22)-\mathrm{Co}(4)-\mathrm{N}(41)$ & 98.6 & & $N(62)-C$ & $\mathrm{o}(5)-\mathrm{N}(81)$ & $164.69(8)$ & & \\
\hline $\mathrm{N}(21)-\mathrm{Co}(4)-\mathrm{N}(41)$ & 91.5 & & $\mathrm{~N}(61)-\mathrm{C}$ & $\mathrm{o}(5)-\mathrm{N}(81)$ & $91.21(9)$ & & \\
\hline $\mathrm{N}(2)-\mathrm{Co}(4)-\mathrm{N}(41)$ & 90.3 & & $\mathrm{~N}(101)$ & $\mathrm{Co}(5)-\mathrm{N}(81)$ & $90.65(9)$ & & \\
\hline $\mathrm{N}-\mathrm{Co}$ eq-N,O angles & & & & & & & \\
\hline $\mathrm{N}(4)-\mathrm{Co}(1)-\mathrm{N}(63)$ & 176. & & $\mathrm{O}(1)-\mathrm{C}$ & $(2)-\mathrm{N}(103)$ & $87.97(7)$ & $\mathrm{O}(1)-\mathrm{Co}(3)-\mathrm{N}(83)$ & $88.98(7)$ \\
\hline $\mathrm{N}(4)-\mathrm{Co}(1)-\mathrm{O}(1)$ & 88.5 & & $\mathrm{O}(1)-\mathrm{C}$ & $(2)-N(43)$ & $88.59(7)$ & $\mathrm{O}(1)-\mathrm{Co}(3)-\mathrm{N}(23)$ & $88.41(7)$ \\
\hline $\mathrm{N}(63)-\mathrm{Co}(1)-\mathrm{O}(1)$ & 87.9 & & $\mathrm{~N}(103)$ & $\mathrm{Co}(2)-\mathrm{N}(43)$ & $176.49(8)$ & $\mathrm{N}(83)-\mathrm{Co}(3)-\mathrm{N}(23)$ & $177.38(8)$ \\
\hline $\mathrm{N}(4)-\mathrm{Co}(1)-\mathrm{N}(64)$ & 102. & & $\mathrm{O}(1)-\mathrm{C}$ & $(2)-\mathrm{N}(44)$ & $126.17(7)$ & $\mathrm{O}(1)-\mathrm{Co}(3)-\mathrm{N}(84)$ & $128.26(7)$ \\
\hline $\mathrm{N}(63)-\mathrm{Co}(1)-\mathrm{N}(64)$ & 79.5 & & $\mathrm{~N}(103)$ & $\mathrm{Co}(2)-\mathrm{N}(44)$ & $101.81(8)$ & $\mathrm{N}(83)-\mathrm{Co}(3)-\mathrm{N}(84)$ & $79.22(8)$ \\
\hline $\mathrm{O}(1)-\mathrm{Co}(1)-\mathrm{N}(64)$ & 128. & & $N(43)-C$ & $\mathrm{o}(2)-\mathrm{N}(44)$ & $79.72(8)$ & $\mathrm{N}(23)-\mathrm{Co}(3)-\mathrm{N}(84)$ & $102.61(8)$ \\
\hline $\mathrm{N}(4)-\mathrm{Co}(1)-\mathrm{N}(5)$ & 79.6 & & $\mathrm{O}(1)-\mathrm{C}$ & $(2)-\mathrm{N}(104)$ & $130.63(7)$ & $\mathrm{O}(1)-\mathrm{Co}(3)-\mathrm{N}(24)$ & $130.00(7)$ \\
\hline $\mathrm{N}(63)-\mathrm{Co}(1)-\mathrm{N}(5)$ & 102.8 & & $\mathrm{~N}(103)$ & $\mathrm{Co}(2)-\mathrm{N}(104)$ & $79.41(8)$ & $\mathrm{N}(83)-\mathrm{Co}(3)-\mathrm{N}(24)$ & $101.99(8)$ \\
\hline $\mathrm{O}(1)-\mathrm{Co}(1)-\mathrm{N}(5)$ & 128. & & $\mathrm{~N}(43)-\mathrm{C}$ & $\mathrm{o}(2)-\mathrm{N}(104)$ & $103.38(8)$ & $\mathrm{N}(23)-\mathrm{Co}(3)-\mathrm{N}(24)$ & $79.54(8)$ \\
\hline $\mathrm{N}(64)-\mathrm{Co}(1)-\mathrm{N}(5)$ & 102. & & $\mathrm{~N}(44)-\mathrm{C}$ & $\mathrm{o}(2)-\mathrm{N}(104)$ & $103.16(8)$ & $\mathrm{N}(84)-\mathrm{Co}(3)-\mathrm{N}(24)$ & 101.74(8) \\
\hline
\end{tabular}


Table S3. Selected bond lengths $(\AA)$ and angles (deg) in $\left[\left\{\mathrm{Co}^{\mathrm{III}}(\mu-\mathrm{bpp})_{3}\right\}_{2} \mathrm{Co}_{3}{ }_{3}\left(\mu_{3}-\right.\right.$ $\mathrm{OH})]\left(\mathrm{ClO}_{4}\right)_{5} \cdot 6 \mathrm{CH}_{3} \mathrm{CN}\left(\mathbf{1}\left(\mathrm{ClO}_{4}\right)_{5} \cdot 6 \mathrm{CH}_{3} \mathrm{CN}\right)$ (apical, ap; equatorial, eq).

\begin{tabular}{|c|c|c|c|c|c|c|c|c|}
\hline \multicolumn{9}{|l|}{ Coap-N distances } \\
\hline $\mathrm{Co}(1)-\mathrm{N}(42)$ & \multicolumn{2}{|c|}{$1.902(6)$} & \multicolumn{2}{|c|}{$\mathrm{Co}(5)-\mathrm{N}(102)$} & $1.910(6)$ & & & \\
\hline $\mathrm{Co}(1)-\mathrm{N}(2)$ & \multicolumn{2}{|c|}{$1.913(6)$} & \multicolumn{2}{|c|}{$\mathrm{Co}(5)-\mathrm{N}(62)$} & $1.922(6)$ & & & \\
\hline $\mathrm{Co}(1)-\mathrm{N}(22)$ & \multicolumn{2}{|c|}{$1.914(6)$} & \multicolumn{2}{|c|}{$\mathrm{Co}(5)-\mathrm{N}(82)$} & $1.923(6)$ & & & \\
\hline $\mathrm{Co}(1)-\mathrm{N}(1)$ & \multicolumn{2}{|c|}{$1.959(7)$} & \multicolumn{2}{|c|}{$\operatorname{Co}(5)-\mathrm{N}(101)$} & $1.972(6)$ & & & \\
\hline $\mathrm{Co}(1)-\mathrm{N}(41)$ & \multicolumn{2}{|c|}{$1.960(6)$} & \multicolumn{2}{|c|}{$\mathrm{Co}(5)-\mathrm{N}(81)$} & $1.982(6)$ & & & \\
\hline $\mathrm{Co}(1)-\mathrm{N}(21)$ & \multicolumn{2}{|c|}{$1.974(7)$} & \multicolumn{2}{|c|}{$\operatorname{Co}(5)-\mathrm{N}(61)$} & $1.989(6)$ & & & \\
\hline \multicolumn{9}{|l|}{ Co eq-N,O distances } \\
\hline $\mathrm{Co}(2)-\mathrm{O}(1 \mathrm{CO})$ & \multicolumn{2}{|c|}{$2.039(5)$} & \multicolumn{2}{|c|}{$\mathrm{Co}(3)-\mathrm{O}(1 \mathrm{CO})$} & $2.027(5)$ & $\mathrm{Co}(4)-\mathrm{N}(104)$ & $2.036(6)$ & \\
\hline $\mathrm{Co}(2)-\mathrm{N}(64)$ & \multicolumn{2}{|c|}{$2.051(6)$} & \multicolumn{2}{|c|}{$\mathrm{Co}(3)-\mathrm{N}(84)$} & $2.039(7)$ & $\mathrm{Co}(4)-\mathrm{O}(1 \mathrm{CO})$ & $2.051(5)$ & \\
\hline $\mathrm{Co}(2)-\mathrm{N}(3)$ & \multicolumn{2}{|c|}{$2.058(6)$} & \multicolumn{2}{|c|}{$\mathrm{Co}(3)-\mathrm{N}(24)$} & $2.053(7)$ & $\mathrm{Co}(4)-\mathrm{N}(44)$ & $2.054(6)$ & \\
\hline $\mathrm{Co}(2)-\mathrm{N}(4)$ & \multicolumn{2}{|c|}{$2.059(6)$} & \multicolumn{2}{|c|}{$\mathrm{Co}(3)-\mathrm{N}(23)$} & $2.071(6)$ & $\mathrm{Co}(4)-\mathrm{N}(43)$ & $2.059(6)$ & \\
\hline $\mathrm{Co}(2)-\mathrm{N}(63)$ & \multicolumn{2}{|c|}{$2.071(6)$} & \multicolumn{2}{|c|}{$\mathrm{Co}(3)-\mathrm{N}(83)$} & $2.078(6)$ & $\mathrm{Co}(4)-\mathrm{N}(103)$ & $2.067(6)$ & \\
\hline \multicolumn{6}{|l|}{$\mathrm{N}$-Coap-N angles } & & $\mathrm{Co}_{\text {eq }}-\mathrm{O}(\mathrm{H})-\mathrm{Co}_{\text {eq }}$ angles & \\
\hline $\mathrm{N}(42)-\mathrm{Co}(1)-\mathrm{N}(2)$ & & & & $\mathrm{N}(102)$ & $\mathrm{Co}(5)-\mathrm{N}(62)$ & $95.7(3)$ & $\mathrm{Co}(3)-\mathrm{O}(1 \mathrm{CO})-\mathrm{Co}(2)$ & $120.6(2)$ \\
\hline $\mathrm{N}(42)-\mathrm{Co}(1)-\mathrm{N}(22)$ & & & & $\mathrm{N}(102)$ & $\mathrm{Co}(5)-\mathrm{N}(82)$ & $96.0(3)$ & $\mathrm{Co}(3)-\mathrm{O}(1 \mathrm{CO})-\mathrm{Co}(4)$ & $121.1(2)$ \\
\hline $\mathrm{N}(2)-\mathrm{Co}(1)-\mathrm{N}(22)$ & & & & $\mathrm{N}(62)-\mathrm{C}$ & $\mathrm{o}(5)-\mathrm{N}(82)$ & $95.6(3)$ & $\mathrm{Co}(2)-\mathrm{O}(1 \mathrm{CO})-\mathrm{Co}(4)$ & $118.1(2)$ \\
\hline $\mathrm{N}(42)-\mathrm{Co}(1)-\mathrm{N}(1)$ & & & & $\mathrm{N}(102)$ & $\mathrm{Co}(5)-\mathrm{N}(101)$ & $81.6(3)$ & & \\
\hline $\mathrm{N}(2)-\mathrm{Co}(1)-\mathrm{N}(1)$ & & & & $\mathrm{N}(62)-\mathrm{C}$ & $\mathrm{o}(5)-\mathrm{N}(101)$ & $90.0(3)$ & $\mathrm{Co}_{\text {eq }}-\mathrm{O}-\mathrm{H}$ angles & \\
\hline $\mathrm{N}(22)-\mathrm{Co}(1)-\mathrm{N}(1)$ & & & $4(3)$ & $\mathrm{N}(82)-\mathrm{C}$ & $\mathrm{o}(5)-\mathrm{N}(101)$ & $174.2(3)$ & $\mathrm{Co}(3)-\mathrm{O}(1 \mathrm{CO})-\mathrm{H}(1 \mathrm{CO})$ & 91.6 \\
\hline $\mathrm{N}(42)-\mathrm{Co}(1)-\mathrm{N}(41)$ & & & & $\mathrm{N}(102)$ & $\mathrm{Co}(5)-\mathrm{N}(81)$ & $88.8(3)$ & $\mathrm{Co}(2)-\mathrm{O}(1 \mathrm{CO})-\mathrm{H}(1 \mathrm{CO})$ & 91.6 \\
\hline $\mathrm{N}(2)-\mathrm{Co}(1)-\mathrm{N}(41)$ & & & $4(3)$ & $\mathrm{N}(62)-\mathrm{C}$ & $\mathrm{o}(5)-\mathrm{N}(81)$ & $175.3(3)$ & $\mathrm{Co}(4)-\mathrm{O}(1 \mathrm{CO})-\mathrm{H}(1 \mathrm{CO})$ & 91.6 \\
\hline $\mathrm{N}(22)-\mathrm{Co}(1)-\mathrm{N}(41)$ & & & & $\mathrm{N}(82)-\mathrm{C}$ & $\mathrm{o}(5)-\mathrm{N}(81)$ & $82.7(3)$ & & \\
\hline $\mathrm{N}(1)-\mathrm{Co}(1)-\mathrm{N}(41)$ & & & & $\mathrm{N}(101)$ & $\mathrm{Co}(5)-\mathrm{N}(81)$ & $91.9(3)$ & & \\
\hline $\mathrm{N}(42)-\mathrm{Co}(1)-\mathrm{N}(21)$ & & & $6(3)$ & $\mathrm{N}(102)$ & $\mathrm{Co}(5)-\mathrm{N}(61)$ & $174.2(3)$ & & \\
\hline $\mathrm{N}(2)-\mathrm{Co}(1)-\mathrm{N}(21)$ & & & & $\mathrm{N}(62)-\mathrm{C}$ & $\mathrm{o}(5)-\mathrm{N}(61)$ & $81.6(3)$ & & \\
\hline $\mathrm{N}(22)-\mathrm{Co}(1)-\mathrm{N}(21)$ & & & & $\mathrm{N}(82)-\mathrm{C}$ & $\mathrm{o}(5)-\mathrm{N}(61)$ & $89.4(3)$ & & \\
\hline $\mathrm{N}(1)-\mathrm{Co}(1)-\mathrm{N}(21)$ & & & & $\mathrm{N}(101)$ & $\mathrm{Co}(5)-\mathrm{N}(61)$ & $93.2(3)$ & & \\
\hline $\mathrm{N}(41)-\mathrm{Co}(1)-\mathrm{N}(21)$ & & & & $\mathrm{N}(81)-\mathrm{C}$ & $\mathrm{o}(5)-\mathrm{N}(61)$ & $94.0(3)$ & & \\
\hline $\mathrm{N}-\mathrm{Co}_{\text {eq- }} \mathrm{N}, \mathrm{O}$ angles & & & & & & & & \\
\hline $\mathrm{O}(1 \mathrm{CO})-\mathrm{Co}(2)-\mathrm{N}(64$ & & & 1(2) & $\mathrm{O}(1 \mathrm{CO})$ & $-\mathrm{Co}(3)-\mathrm{N}(84)$ & $132.0(2)$ & N(104)-Co(4)-O(1CO) & $132.8(2)$ \\
\hline $\mathrm{O}(1 \mathrm{CO})-\mathrm{Co}(2)-\mathrm{N}(3)$ & & & & $\mathrm{O}(1 \mathrm{CO}$ & $-\mathrm{Co}(3)-\mathrm{N}(24)$ & $129.7(2)$ & $\mathrm{N}(104)-\mathrm{Co}(4)-\mathrm{N}(44)$ & $98.9(2)$ \\
\hline $\mathrm{N}(64)-\mathrm{Co}(2)-\mathrm{N}(3)$ & & & $5(3)$ & $\mathrm{N}(84)-\mathrm{C}$ & $\mathrm{o}(3)-\mathrm{N}(24)$ & $98.2(3)$ & $\mathrm{O}(1 \mathrm{CO})-\mathrm{Co}(4)-\mathrm{N}(44)$ & $128.2(2)$ \\
\hline $\mathrm{O}(1 \mathrm{CO})-\mathrm{Co}(2)-\mathrm{N}(4)$ & & & $8(2)$ & $\mathrm{O}(1 \mathrm{CO})$ & $-\mathrm{Co}(3)-\mathrm{N}(23)$ & $86.7(2)$ & $\mathrm{N}(104)-\mathrm{Co}(4)-\mathrm{N}(43)$ & $108.0(2)$ \\
\hline $\mathrm{N}(64)-\mathrm{Co}(2)-\mathrm{N}(4)$ & & & & $\mathrm{N}(84)-\mathrm{C}$ & $\mathrm{o}(3)-\mathrm{N}(23)$ & $106.0(3)$ & $\mathrm{O}(1 \mathrm{CO})-\mathrm{Co}(4)-\mathrm{N}(43)$ & $85.7(2)$ \\
\hline $\mathrm{N}(3)-\mathrm{Co}(2)-\mathrm{N}(4)$ & & & & $\mathrm{N}(24)-\mathrm{C}$ & $\mathrm{o}(3)-\mathrm{N}(23)$ & $80.1(3)$ & $\mathrm{N}(44)-\mathrm{Co}(4)-\mathrm{N}(43)$ & $79.8(2)$ \\
\hline $\mathrm{O}(1 \mathrm{CO})-\mathrm{Co}(2)-\mathrm{N}(63$ & & & & $\mathrm{O}(1 \mathrm{CO}$ & $-\mathrm{Co}(3)-\mathrm{N}(83)$ & $85.4(2)$ & $\mathrm{N}(104)-\mathrm{Co}(4)-\mathrm{N}(103)$ & $79.2(2)$ \\
\hline $\mathrm{N}(64)-\mathrm{Co}(2)-\mathrm{N}(63)$ & & & & $\mathrm{N}(84)-\mathrm{C}$ & $\mathrm{o}(3)-\mathrm{N}(83)$ & $79.3(3)$ & $\mathrm{O}(1 \mathrm{CO})-\mathrm{Co}(4)-\mathrm{N}(103)$ & $85.4(2)$ \\
\hline $\mathrm{N}(3)-\mathrm{Co}(2)-\mathrm{N}(63)$ & & & $6(2)$ & $\mathrm{N}(24)-\mathrm{C}$ & $\mathrm{o}(3)-\mathrm{N}(83)$ & $105.2(3)$ & $\mathrm{N}(44)-\mathrm{Co}(4)-\mathrm{N}(103)$ & $104.9(2)$ \\
\hline $\mathrm{N}(4)-\mathrm{Co}(2)-\mathrm{N}(63)$ & & & $6(2)$ & $\mathrm{N}(23)-\mathrm{C}$ & $\mathrm{o}(3)-\mathrm{N}(83)$ & $172.1(2)$ & $\mathrm{N}(43)-\mathrm{Co}(4)-\mathrm{N}(103)$ & $171.0(2)$ \\
\hline
\end{tabular}


Table S4. Selected Bond Lengths ( $\AA$ ) and Angles (deg) in $\left[\left\{\mathrm{Co}^{\mathrm{II}}(\mu-\mathrm{bpp})_{3}\right\}_{2} \mathrm{Co}^{\mathrm{I}} \mathrm{Co}_{2}{ }_{2}\left(\mu_{3}-\right.\right.$ $\mathrm{OH})]\left(\mathrm{ClO}_{4}\right)_{2} \cdot 2 \mathrm{CH}_{3} \mathrm{CN}\left(\mathbf{1}\left(\mathrm{ClO}_{4}\right)_{2} \cdot 2 \mathrm{CH}_{3} \mathrm{CN}\right)$ (apical, ap; equatorial, eq).

\begin{tabular}{|c|c|c|c|c|c|c|}
\hline \multicolumn{2}{|l|}{ Coap-N distances } & \multicolumn{5}{|c|}{ Co eq-N,O distances } \\
\hline $\mathrm{Co}(1)-\mathrm{N}(22)$ & $2.080(6)$ & $\mathrm{Co}(2)-\mathrm{O}(1 \mathrm{M})$ & $1.958(3)$ & \multicolumn{2}{|c|}{$\mathrm{Co}(3)-\mathrm{N}(23 ”)$} & $2.000(6)$ \\
\hline $\mathrm{Co}(1)-\mathrm{N}(2)$ & $2.090(5)$ & $\mathrm{Co}(2)-\mathrm{N}(43 ”)$ & $2.052(6)$ & \multicolumn{2}{|c|}{$\mathrm{Co}(3)-\mathrm{N}(23)$} & $2.000(6)$ \\
\hline $\mathrm{Co}(1)-\mathrm{N}(42)$ & $2.124(6)$ & $\mathrm{Co}(2)-\mathrm{N}(3)$ & $2.054(5)$ & \multicolumn{2}{|c|}{$\mathrm{Co}(3)-\mathrm{O}(1 \mathrm{M})$} & $2.056(6)$ \\
\hline $\mathrm{Co}(1)-\mathrm{N}(21)$ & $2.188(6)$ & $\mathrm{Co}(2)-\mathrm{N}(4)$ & $2.081(5)$ & \multicolumn{2}{|c|}{$\mathrm{Co}(3)-\mathrm{N}(24)$} & $2.069(7)$ \\
\hline $\mathrm{Co}(1)-\mathrm{N}(1)$ & $2.208(5)$ & $\operatorname{Co}(2)-\mathrm{N}\left(44^{\prime \prime}\right)$ & $2.108(6)$ & \multicolumn{2}{|c|}{$\mathrm{Co}(3)-\mathrm{N}(24 ”)$} & $2.069(7)$ \\
\hline $\mathrm{Co}(1)-\mathrm{N}(41)$ & $2.217(6)$ & & & & & \\
\hline \multicolumn{7}{|l|}{ O-H distances } \\
\hline $\mathrm{O}(1 \mathrm{M})-\mathrm{H}(1 \mathrm{M})$ & \multicolumn{6}{|c|}{$0.816(10)$} \\
\hline \multicolumn{3}{|l|}{$\mathrm{N}-\mathrm{Co}_{\mathrm{ap}}-\mathrm{N}$ angles } & \multicolumn{4}{|c|}{$\mathrm{Co}_{\mathrm{eq}}-\mathrm{O}(\mathrm{H})-\mathrm{Co}_{\mathrm{eq}}$ angles } \\
\hline \multicolumn{2}{|l|}{$\mathrm{N}(22)-\mathrm{Co}(1)-\mathrm{N}(2)$} & $97.4(2)$ & \multicolumn{2}{|c|}{$\mathrm{Co}(2 ")-\mathrm{O}(1 \mathrm{M})-\mathrm{Co}(2)$} & \multicolumn{2}{|c|}{$126.3(3)$} \\
\hline \multicolumn{2}{|l|}{$\mathrm{N}(22)-\mathrm{Co}(1)-\mathrm{N}(42)$} & $101.5(2)$ & \multicolumn{2}{|c|}{$\mathrm{Co}(2 ”)-\mathrm{O}(1 \mathrm{M})-\mathrm{Co}(3)$} & \multicolumn{2}{|c|}{$116.86(17)$} \\
\hline \multicolumn{2}{|l|}{$\mathrm{N}(2)-\mathrm{Co}(1)-\mathrm{N}(42)$} & 98.1(2) & \multicolumn{2}{|c|}{$\mathrm{Co}(2)-\mathrm{O}(1 \mathrm{M})-\mathrm{Co}(3)$} & \multicolumn{2}{|c|}{$116.87(17)$} \\
\hline \multicolumn{2}{|l|}{$\mathrm{N}(22)-\mathrm{Co}(1)-\mathrm{N}(21)$} & $76.4(2)$ & \multicolumn{4}{|c|}{$\mathrm{Co}_{\mathrm{eq}}-\mathrm{O}-\mathrm{H}$ angles } \\
\hline $\mathrm{N}(2)-\mathrm{Co}(1)-\mathrm{N}(21)$ & & $96.7(2)$ & $\mathrm{Co}(2 ")-\mathrm{O}(1 \mathrm{M})$ & $1 \mathrm{M})$ & $83(5)$ & \\
\hline $\mathrm{N}(42)-\mathrm{Co}(1)-\mathrm{N}(21)$ & & 165.1(2) & $\mathrm{Co}(2)-\mathrm{O}(1 \mathrm{M})-$ & & $95(4)$ & \\
\hline $\mathrm{N}(22)-\mathrm{Co}(1)-\mathrm{N}(1)$ & & $164.0(2)$ & $\mathrm{Co}(3)-\mathrm{O}(1 \mathrm{M})-$ & & $92(9)$ & \\
\hline $\mathrm{N}(2)-\mathrm{Co}(1)-\mathrm{N}(1)$ & & $76.2(2)$ & & & & \\
\hline $\mathrm{N}(42)-\mathrm{Co}(1)-\mathrm{N}(1)$ & & $94.0(2)$ & & & & \\
\hline $\mathrm{N}(21)-\mathrm{Co}(1)-\mathrm{N}(1)$ & & $89.67(19)$ & & & & \\
\hline $\mathrm{N}(22)-\mathrm{Co}(1)-\mathrm{N}(41)$ & & $98.5(2)$ & & & & \\
\hline $\mathrm{N}(2)-\mathrm{Co}(1)-\mathrm{N}(41)$ & & $163.8(2)$ & & & & \\
\hline $\mathrm{N}(42)-\mathrm{Co}(1)-\mathrm{N}(41)$ & & $76.3(2)$ & & & & \\
\hline $\mathrm{N}(21)-\mathrm{Co}(1)-\mathrm{N}(41)$ & & $89.4(2)$ & & & & \\
\hline $\mathrm{N}(1)-\mathrm{Co}(1)-\mathrm{N}(41)$ & & $89.0(2)$ & & & & \\
\hline $\mathrm{N}-\mathrm{Co}_{\text {eq- }} \mathrm{N}, \mathrm{O}$ angles & & & & & & \\
\hline $\mathrm{O}(1 \mathrm{M})-\mathrm{Co}(2)-\mathrm{N}\left(43^{\prime}\right.$ & & $91.8(2)$ & $\mathrm{N}(23 ")-\mathrm{Co}(3)-$ & & 179.4 & \\
\hline $\mathrm{O}(1 \mathrm{M})-\mathrm{Co}(2)-\mathrm{N}(3)$ & & $91.22(18)$ & $\mathrm{N}(23 ”)-\mathrm{Co}(3)-$ & & 89.69 & \\
\hline $\mathrm{N}(43 ")-\mathrm{Co}(2)-\mathrm{N}(3)$ & & 177.0(2) & $\mathrm{N}(23)-\mathrm{Co}(3)-\mathrm{C}$ & & 89.70 & \\
\hline $\mathrm{O}(1 \mathrm{M})-\mathrm{Co}(2)-\mathrm{N}(4)$ & & 121.3(2) & $\mathrm{N}\left(23^{\prime \prime}\right)-\mathrm{Co}(3)-$ & & 101.0 & \\
\hline N(43”)-Co(2)-N(4) & & $99.6(2)$ & $\mathrm{N}(23)-\mathrm{Co}(3)-\mathrm{N}$ & & 79.3( & \\
\hline N(3)-Co(2)-N(4) & & $78.6(2)$ & $\mathrm{O}(1 \mathrm{M})-\mathrm{Co}(3)-$ & & 127.0 & \\
\hline $\mathrm{O}(1 \mathrm{M})-\mathrm{Co}(2)-\mathrm{N}\left(44^{\prime}\right.$ & & 133.3(2) & $\mathrm{N}(23 ”)-\mathrm{Co}(3)-$ & 4”) & 79.3( & \\
\hline $\mathrm{N}\left(43^{\prime \prime}\right)-\mathrm{Co}(2)-\mathrm{N}\left(44^{\prime}\right.$ & & $79.8(2)$ & $\mathrm{N}(23)-\mathrm{Co}(3)-\mathrm{N}$ & & 101.0 & \\
\hline $\mathrm{N}(3)-\mathrm{Co}(2)-\mathrm{N}(44 ”)$ & & $98.3(2)$ & $\mathrm{O}(1 \mathrm{M})-\mathrm{Co}(3)-$ & & 127.0 & \\
\hline $\mathrm{N}(4)-\mathrm{Co}(2)-\mathrm{N}(44 ”)$ & & $105.4(2)$ & $\mathrm{N}(24)-\mathrm{Co}(3)-\mathrm{N}$ & & 105.9 & \\
\hline
\end{tabular}


Table S5. Crystallographic refinement data for the structure of $\left[\mathrm{Co}^{\mathrm{III}}(\mathrm{bpp})_{3}\right] \cdot 0.5 \mathrm{CH}_{3} \mathrm{CN} \cdot\left(\mathrm{CH}_{3}\right)_{2} \mathrm{CO} \bullet 0.5\left(\left(\mathrm{CH}_{3}\right)_{2} \mathrm{CH}\right)_{2} \mathrm{O}\left(2 \cdot 0.5 \mathrm{CH}_{3} \mathrm{CN} \bullet\left(\mathrm{CH}_{3}\right)_{2} \mathrm{CO} \cdot 0.5\left(\left(\mathrm{CH}_{3}\right)_{2} \mathrm{CH}\right)_{2} \mathrm{O}\right)$.

\begin{tabular}{lc}
\hline & $\mathbf{2} \cdot 0.5 \mathrm{CH}_{3} \mathrm{CN} \cdot\left(\mathrm{CH}_{3}\right)_{2} \mathrm{CO} \cdot 0.5\left(\left(\mathrm{CH}_{3}\right)_{2} \mathrm{CH}\right)_{2} \mathrm{O}$ \\
\hline CCDC reference & 1956214 \\
Empirical formula & $\mathrm{C}_{46} \mathrm{H}_{41.50} \mathrm{CoN}_{12.50} \mathrm{O}_{1.50}$ \\
Formula weight & 852.34 \\
Colour, shape & red, block \\
Crystal size, $\mathrm{mm}$ & $0.296 \times 0.234 \times 0.135$ \\
Crystal system & Orthorhombic \\
Space group & $P b c n$ \\
$a, \AA$ & $17.3087(4)$ \\
$b, \AA$ & $16.6078(4)$ \\
$c, \AA$ & $28.5274(10)$ \\
$\alpha$, deg. & 90 \\
$\beta$, deg. & 90 \\
$\gamma$, deg. & 90 \\
$V, \AA^{3}$ & $8200.4(4)$ \\
$Z$ & 8 \\
$T, \mathrm{~K}$ & $150(2)$ \\
$\lambda($ calc $), \mathrm{Mg} / \mathrm{m}^{3}$ & 1.381 \\
$\beta$, mm & -1 \\
$\theta$ range, deg. & 0.474 \\
rflcn coll/obsv (Rint) & 2.220 to 26.371 \\
GooF & $44448 / 8230(0.0872)$ \\
$R 1$ & 1.055 \\
$w R 2$ & 0.0584 \\
\hline & 0.1570 \\
\hline
\end{tabular}

Table S6. Selected bond lengths $(\AA)$ and angles $(\mathrm{deg})$ for $\left[\mathrm{Co}{ }^{\mathrm{III}}(\mathrm{bpp})_{3}\right] \cdot 0.5 \mathrm{CH}_{3} \mathrm{CN} \bullet$ $\left.\left(\mathrm{CH}_{3}\right)_{2} \mathrm{CO} \bullet 0.5\left(\left(\mathrm{CH}_{3}\right)_{2} \mathrm{CH}\right)_{2} \mathrm{O}\left(2 \cdot 0.5 \mathrm{CH}_{3} \mathrm{CN} \bullet\left(\mathrm{CH}_{3}\right)_{2} \mathrm{CO} \bullet 0.5\left(\left(\mathrm{CH}_{3}\right)_{2} \mathrm{CH}\right)_{2} \mathrm{O}\right)\right)$.

\begin{tabular}{llll}
\hline $\operatorname{Co}(1)-\mathrm{N}(22)$ & $1.882(3)$ & $\mathrm{Co}(1)-\mathrm{N}(21)$ & $1.933(3)$ \\
$\mathrm{Co}(1)-\mathrm{N}(2)$ & $1.895(3)$ & $\mathrm{Co}(1)-\mathrm{N}(41)$ & $1.963(3)$ \\
$\mathrm{Co}(1)-\mathrm{N}(42)$ & $1.896(3)$ & $\mathrm{Co}(1)-\mathrm{N}(1)$ & $1.967(3)$ \\
& & & \\
$\mathrm{N}(22)-\mathrm{Co}(1)-\mathrm{N}(2)$ & $93.63(12)$ & $\mathrm{N}(42)-\mathrm{Co}(1)-\mathrm{N}(41)$ & $82.05(11)$ \\
$\mathrm{N}(22)-\mathrm{Co}(1)-\mathrm{N}(42)$ & $90.46(11)$ & $\mathrm{N}(21)-\mathrm{Co}(1)-\mathrm{N}(41)$ & $172.65(11)$ \\
$\mathrm{N}(2)-\mathrm{Co}(1)-\mathrm{N}(42)$ & $175.35(11)$ & $\mathrm{N}(22)-\mathrm{Co}(1)-\mathrm{N}(1)$ & $174.95(11)$ \\
$\mathrm{N}(22)-\mathrm{Co}(1)-\mathrm{N}(21)$ & $82.39(11)$ & $\mathrm{N}(2)-\mathrm{Co}(1)-\mathrm{N}(1)$ & $82.13(11)$ \\
$\mathrm{N}(2)-\mathrm{Co}(1)-\mathrm{N}(21)$ & $91.38(12)$ & $\mathrm{N}(42)-\mathrm{Co}(1)-\mathrm{N}(1)$ & $93.89(11)$ \\
$\mathrm{N}(42)-\mathrm{Co}(1)-\mathrm{N}(21)$ & $91.35(11)$ & $\mathrm{N}(21)-\mathrm{Co}(1)-\mathrm{N}(1)$ & $94.93(11)$ \\
$\mathrm{N}(22)-\mathrm{Co}(1)-\mathrm{N}(41)$ & $94.37(11)$ & $\mathrm{N}(41)-\mathrm{Co}(1)-\mathrm{N}(1)$ & $88.77(11)$ \\
$\mathrm{N}(2)-\mathrm{Co}(1)-\mathrm{N}(41)$ & $95.42(12)$ & & \\
\hline
\end{tabular}


(A)
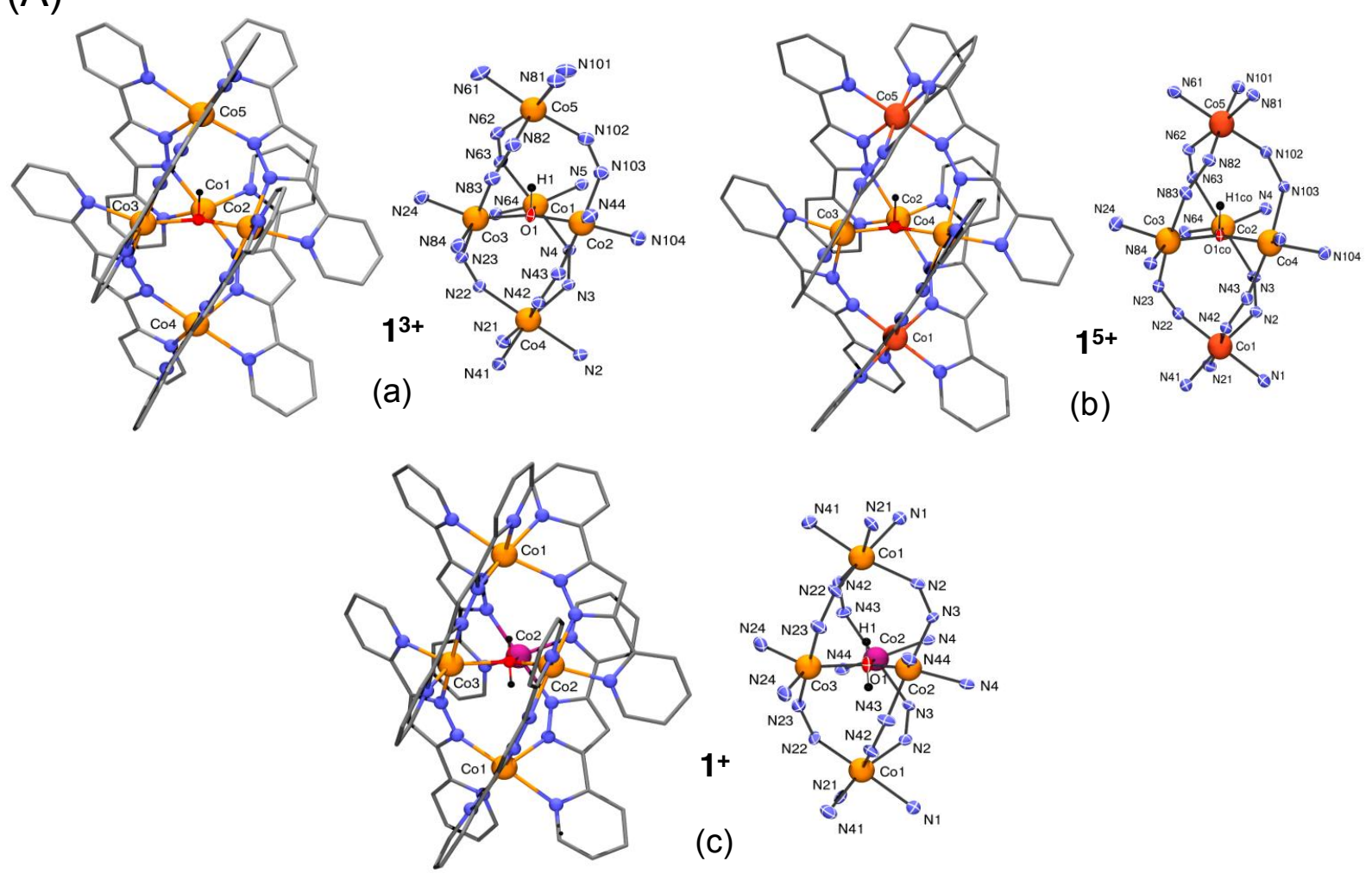

(B)
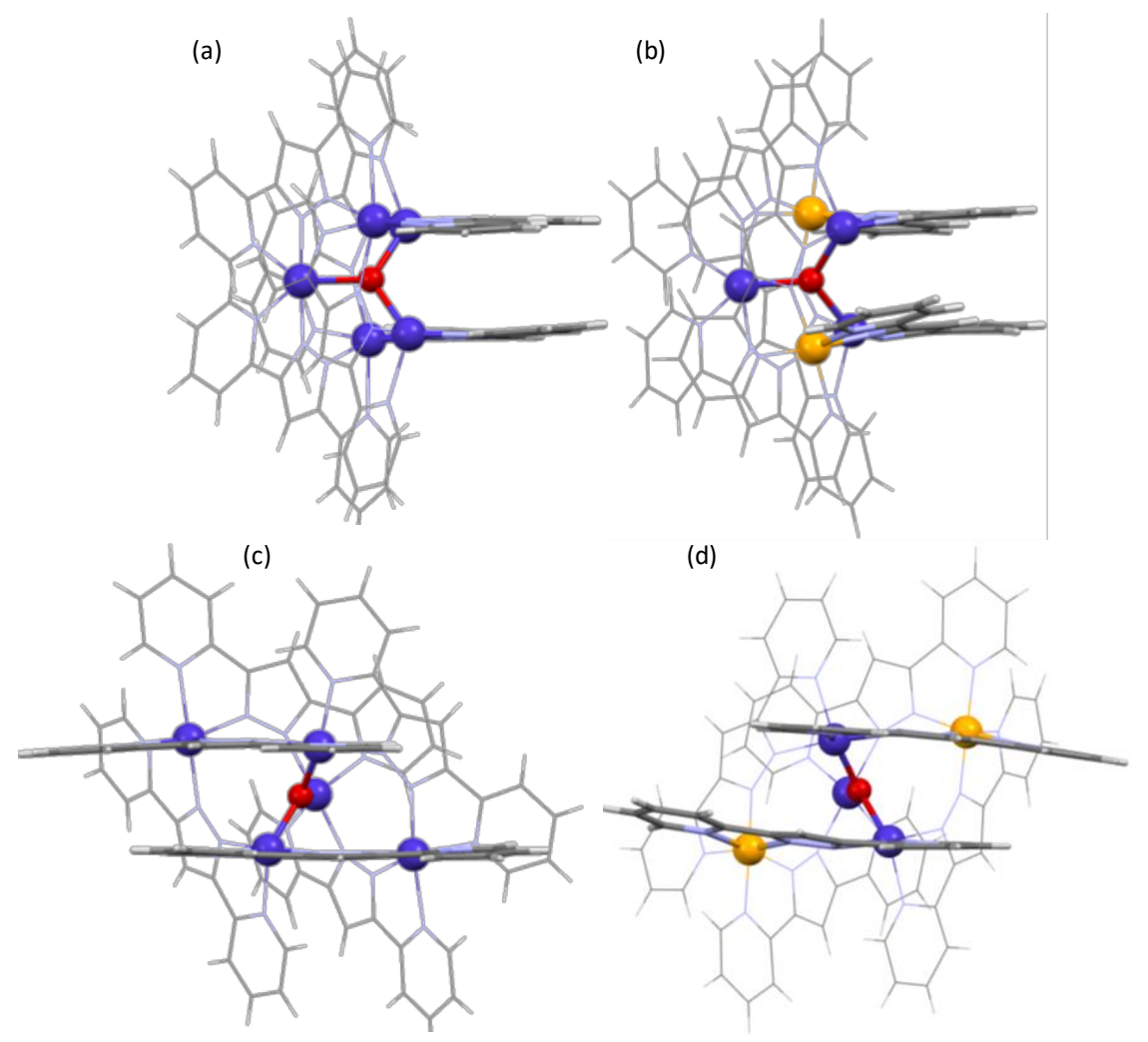

Figure S1. (A) ORTEP representation with $50 \%$ probability thermal of the molecular structure of cation $\mathbf{1}^{3+}(\mathrm{a}), \mathbf{1}^{5+}$ (b) and $\mathbf{1}^{2+}$ and the corresponding metallic cores including the first coordination spheres of the metal ions are shown. (B) Two crystallographic views of $\mathbf{1}^{3+}(\mathrm{a}, \mathrm{c})$ and $\mathbf{1}^{5+}(\mathrm{b}, \mathrm{d})$; color code: Co(II), blue; $\mathrm{Co}(\mathrm{III})$, orange; $\mathrm{O}$, red; $\mathrm{N}$, light blue; $\mathrm{C}$, grey. 
As typically found in complexes with the bpp- ligand, the Co- $\mathrm{N}_{\text {pyrazole }}$ distances are shorter

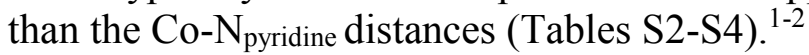

\section{Electrochemical data and UV-Visible absorption spectra of the complexes}

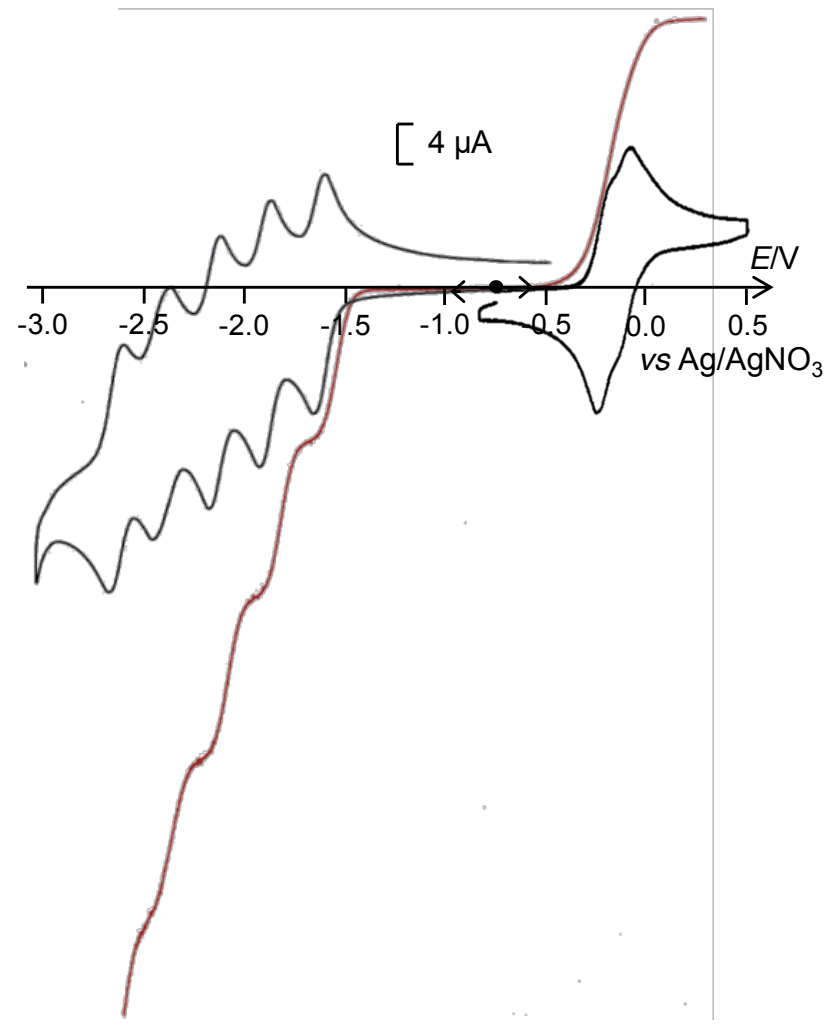

Figure S2. Cyclic voltammograms in $\mathrm{CH}_{3} \mathrm{CN}, 0.05 \mathrm{M}\left[\mathrm{Bu}_{4} \mathrm{~N}_{\mathrm{ClO}}\right.$ of a $0.5 \mathrm{mM}$ solution of $\mathbf{1}^{3+}$ at a $\mathrm{Pt}$ electrode (diameter $3 \mathrm{~mm}$ ) for scan range between -0.82 and $+0.5 \mathrm{~V}$ and at a carbon electrode (diameter $3 \mathrm{~mm}$ ) for scan range between -0.5 and $-3 \mathrm{~V}$ (black) with a scan rate of $100 \mathrm{mV} . \mathrm{s}^{-1}$. Voltammograms at a carbon rotating disk electrode (RDE), rotation rate $600 \mathrm{rpm}$ with a scan rate of $10 \mathrm{mV} \cdot \mathrm{s}^{-1}$ (red).
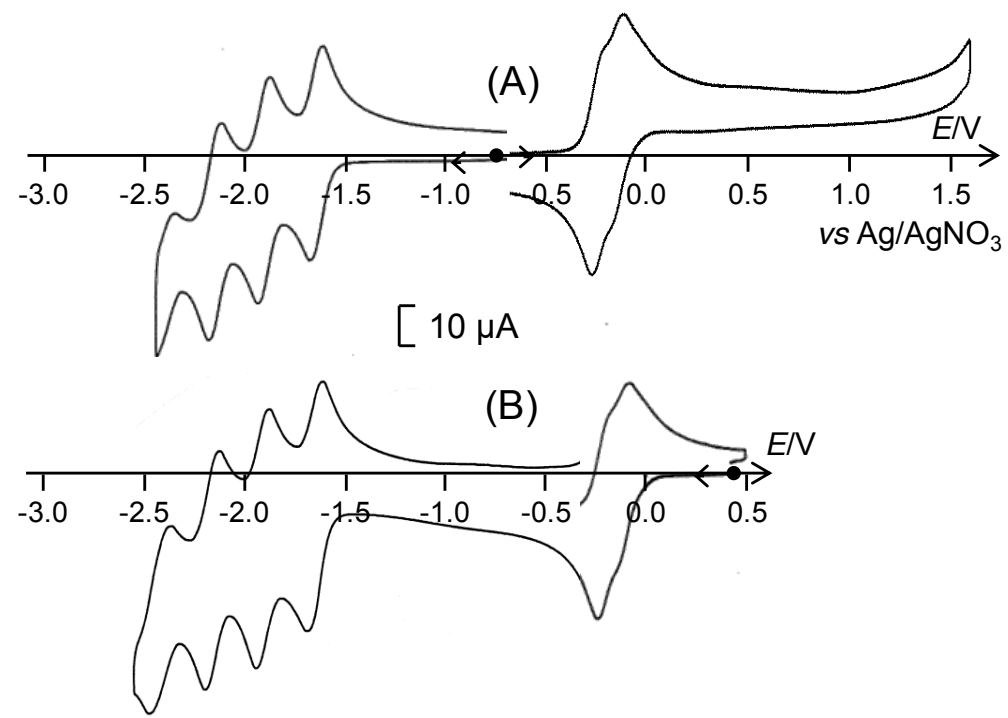

Figure S3. Cyclic voltammograms at a Pt electrode (diameter $5 \mathrm{~mm}$ ) in $\mathrm{CH}_{3} \mathrm{CN}, 0.05 \mathrm{M}\left[\mathrm{Bu}_{4} \mathrm{~N}\right] \mathrm{ClO}_{4}$ of (A) a $0.54 \mathrm{mM}$ solution of $\mathbf{1}^{3+}$, (B) after exhaustive oxidation at $+0.25 \mathrm{~V}$ of the (A) solution (formation of $\mathbf{1}^{5+}$ ) with a scan rate of $100 \mathrm{mV} \cdot \mathrm{s}^{-1}$. 


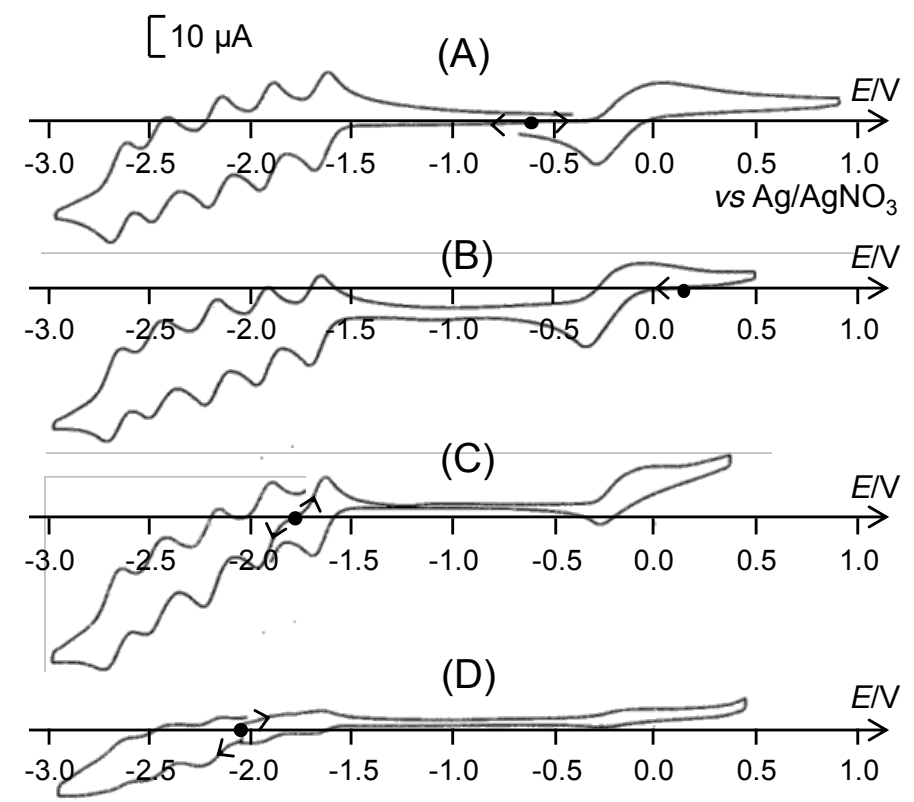

Figure S4. Cyclic voltammograms at a carbon electrode (diameter $3 \mathrm{~mm}$ ) in $\mathrm{CH}_{3} \mathrm{CN}, 0.05 \mathrm{M}$ $\left[\mathrm{Bu}_{4} \mathrm{~N}\right] \mathrm{ClO}_{4}$ of $(\mathrm{A})$ a $0.50 \mathrm{mM}$ solution of $\mathbf{1}^{3+}$, (B) after exhaustive oxidation at $+0.25 \mathrm{~V}$ of the (A) solution (formation of $\mathbf{1}^{5+}$ ), (C) after exhaustive reduction at $-1.75 \mathrm{~V}$ of the (A) solution (formation of $\mathbf{1}^{\mathbf{2}}$ ), (D) after exhaustive reduction at $-2.05 \mathrm{~V}$ of the (C) solution (formation of $\mathbf{1}^{+}$, the compound precipitated) with a scan rate of $100 \mathrm{mV} \cdot \mathrm{s}^{-1}$. 

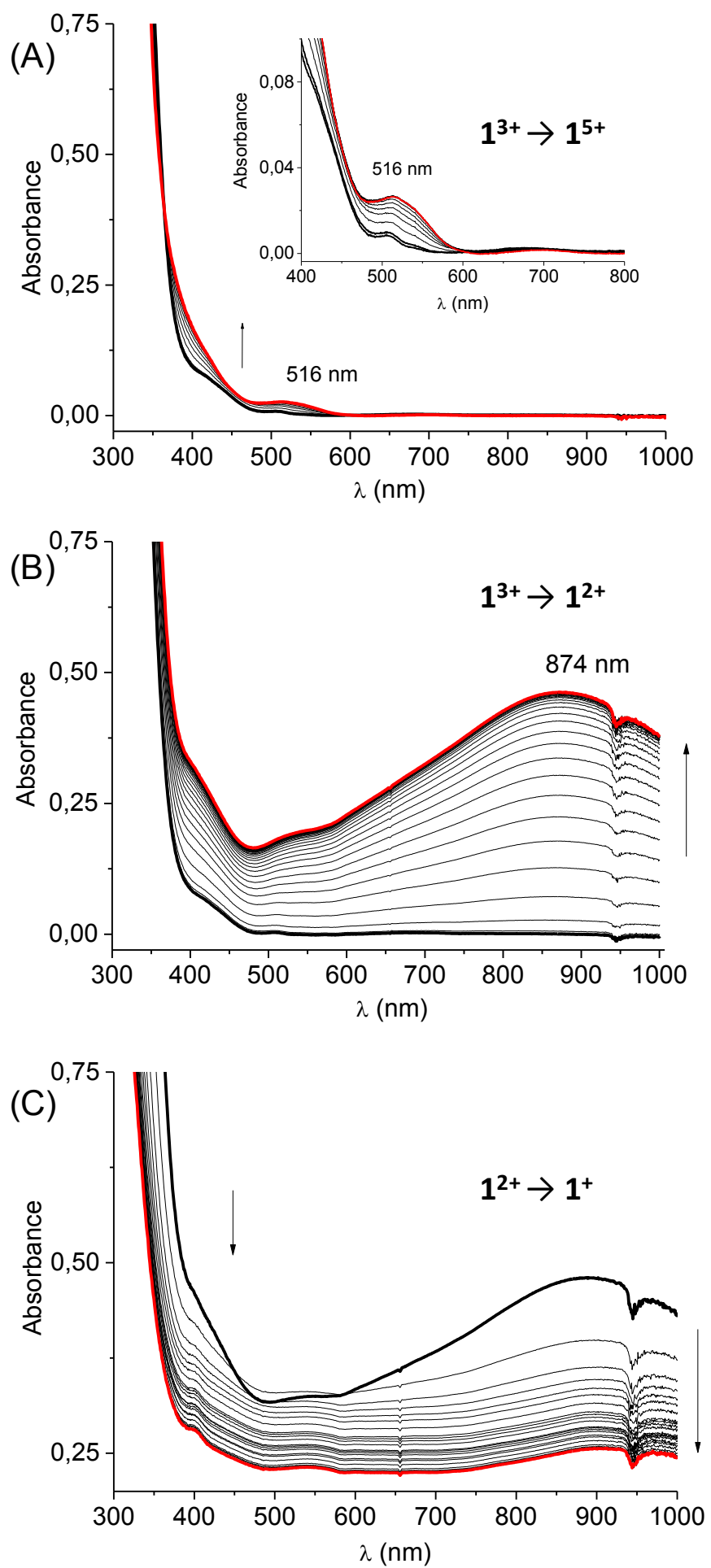

Figure S5. UV-vis absorption monitoring during electrolyses of a $0.50 \mathrm{mM}$ solution of $\mathbf{1}^{3+}$ in $\mathrm{CH}_{3} \mathrm{CN}$, $0.05 \mathrm{M}\left[\mathrm{Bu}_{4} \mathrm{~N}\right] \mathrm{ClO}_{4}$ : (A) oxidation at $0.25 \mathrm{~V}$ (conversion of $\mathbf{1}^{3+}$ into $\mathbf{1}^{5+}$ after two electrons exchanged); (B) reduction at $-1.75 \mathrm{~V}$ (conversion of $\mathbf{1}^{3+}$ into $\mathbf{1}^{\mathbf{2 +}}$ after exchange of one electron); (C) reduction at $2.05 \mathrm{~V}$ (from $\mathbf{1}^{2+}$ to $\mathbf{1}^{+}$after exchange of one electro), the decrease of the absorbance is due to the progressive precipitation of $\mathbf{1}^{+}$during the electrolysis. $l n=1 \mathrm{~mm}$. 


\section{Magnetic properties of the complexes}
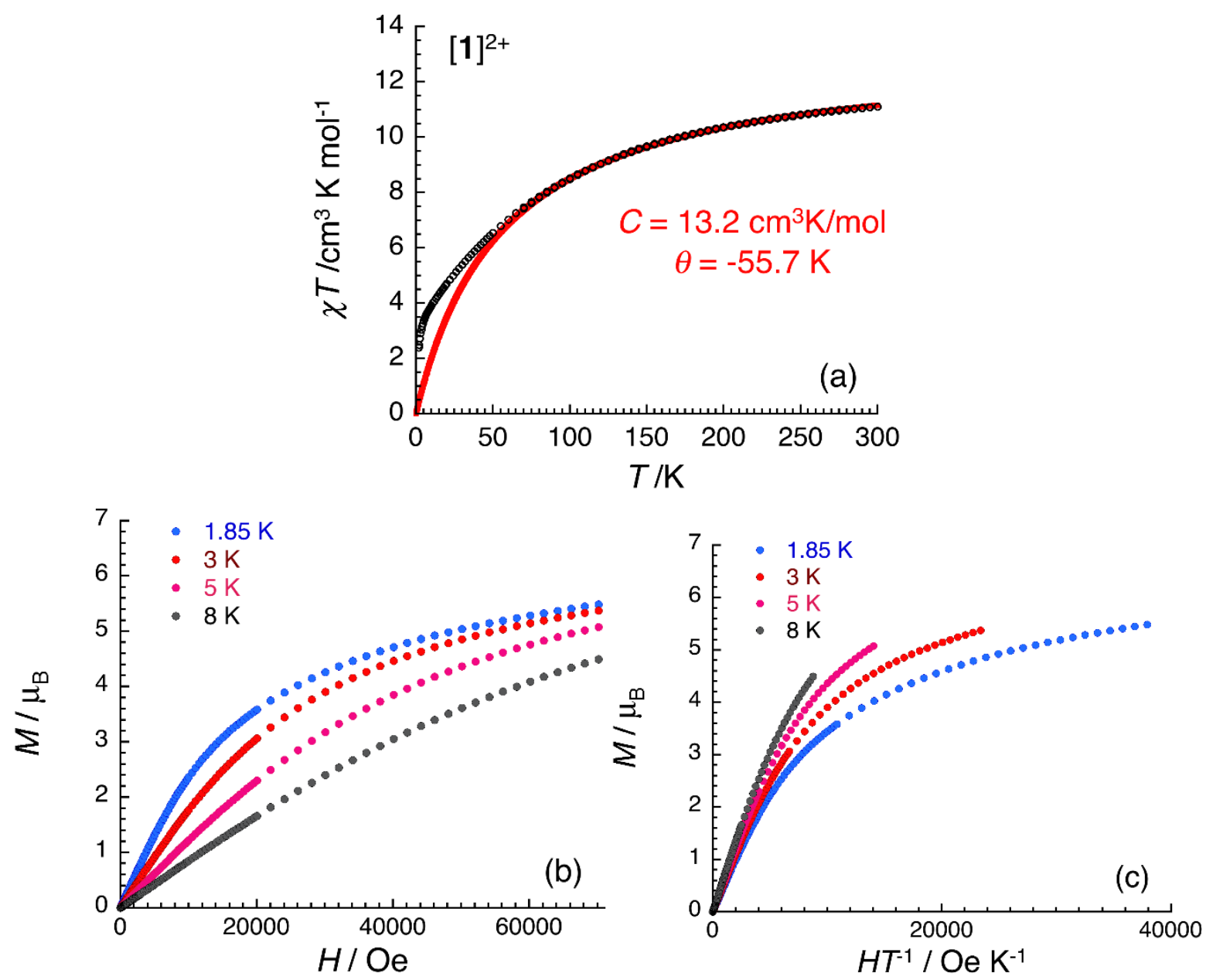

Figure S6. (a) Temperature dependence of the $\chi T$ product (where $\chi$ is the molar magnetic susceptibility that equals $M / H$ per complex) collected in an applied dc magnetic field of $0.1 \mathrm{~T}$ for $1\left(\mathrm{ClO}_{4}\right)_{2} \cdot 2 \mathrm{CH}_{3} \mathrm{CN}$. The solid red line is the best fit of the experimental data to a Curie-Weiss law (see main text). Field dependence of the magnetization, $M$, for $1\left(\mathrm{ClO}_{4}\right)_{2} \cdot 2 \mathrm{CH}_{3} \mathrm{CN}$ below $8 \mathrm{~K}$ (scanning at $100-400$ Oe.min ${ }^{1}$ for $H<1 \mathrm{~T}$ and $500-2500 \mathrm{Oe} \cdot \mathrm{min}^{-1}$ for $H>1 \mathrm{~T}$ ) plotted as (b) $M$ vs $H$ and (c) $M$ vs $H / T$ plots. 

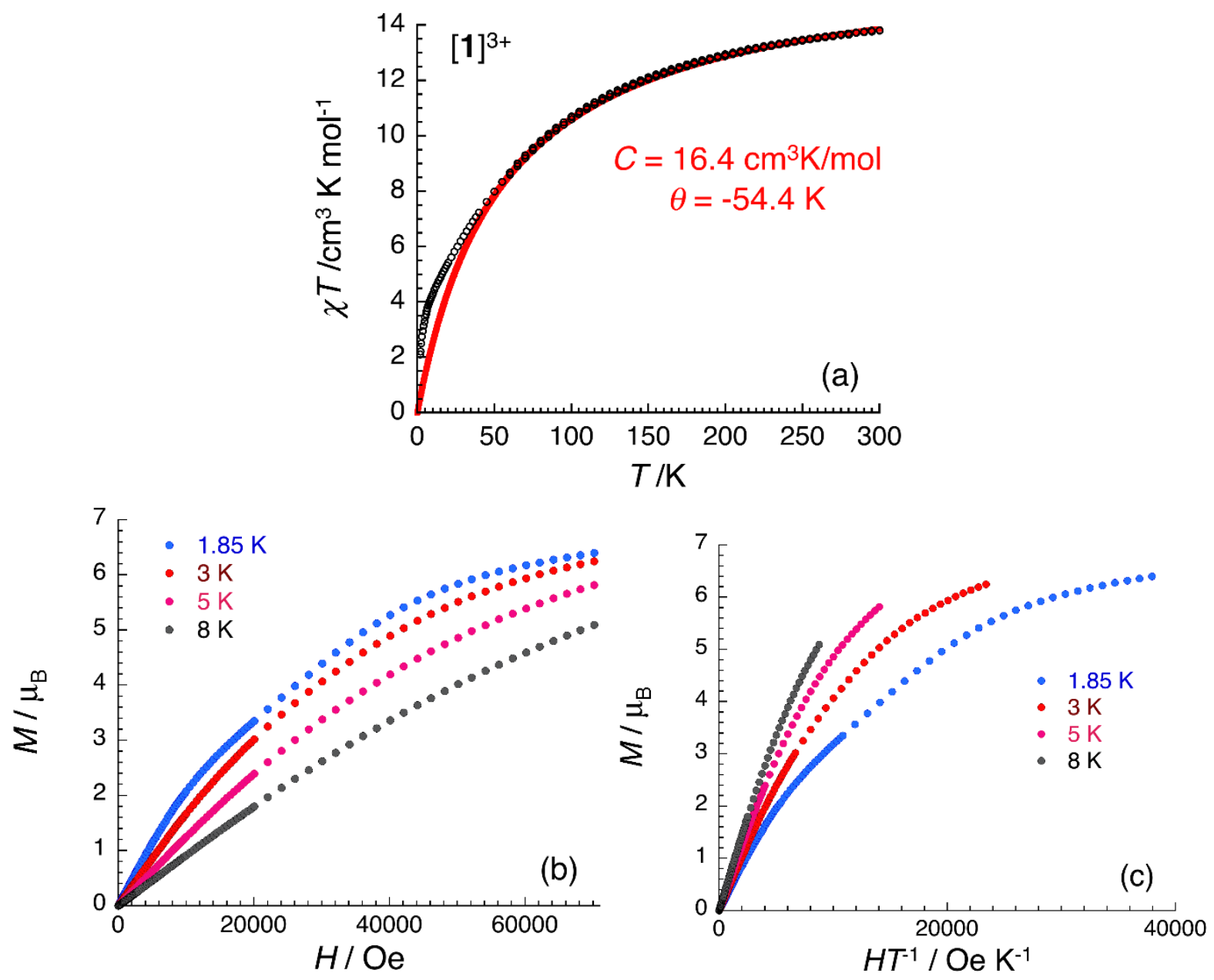

Figure S7. (a) Temperature dependence of the $\chi T$ product (where $\chi$ is the molar magnetic susceptibility that equals $M / H$ per complex) collected in an applied dc magnetic field of $0.1 \mathrm{~T}$ for $\mathbf{1}\left(\mathrm{BF}_{4}\right)_{3} \cdot 3.75 \mathrm{CH}_{3} \mathrm{CN} \cdot 0.33 \mathrm{H}_{2} \mathrm{O}$. The solid red line is the best fit of the experimental data to a Curie-Weiss law (see main text). Field dependence of the magnetization, $M$, for $1\left(\mathrm{BF}_{4}\right)_{3} \cdot 3.75 \mathrm{CH}_{3} \mathrm{CN} \cdot 0.33 \mathrm{H}_{2} \mathrm{O}$ below $8 \mathrm{~K}$ (scanning at $100-400 \mathrm{Oe} \cdot \mathrm{min}^{-1}$ for $H<1 \mathrm{~T}$ and $500-2500$ Oe. $\mathrm{min}^{-1}$ for $H>1 \mathrm{~T}$ ) plotted as (b) $M$ vs $H$ and (c) $M$ vs $H / T$ plots. 

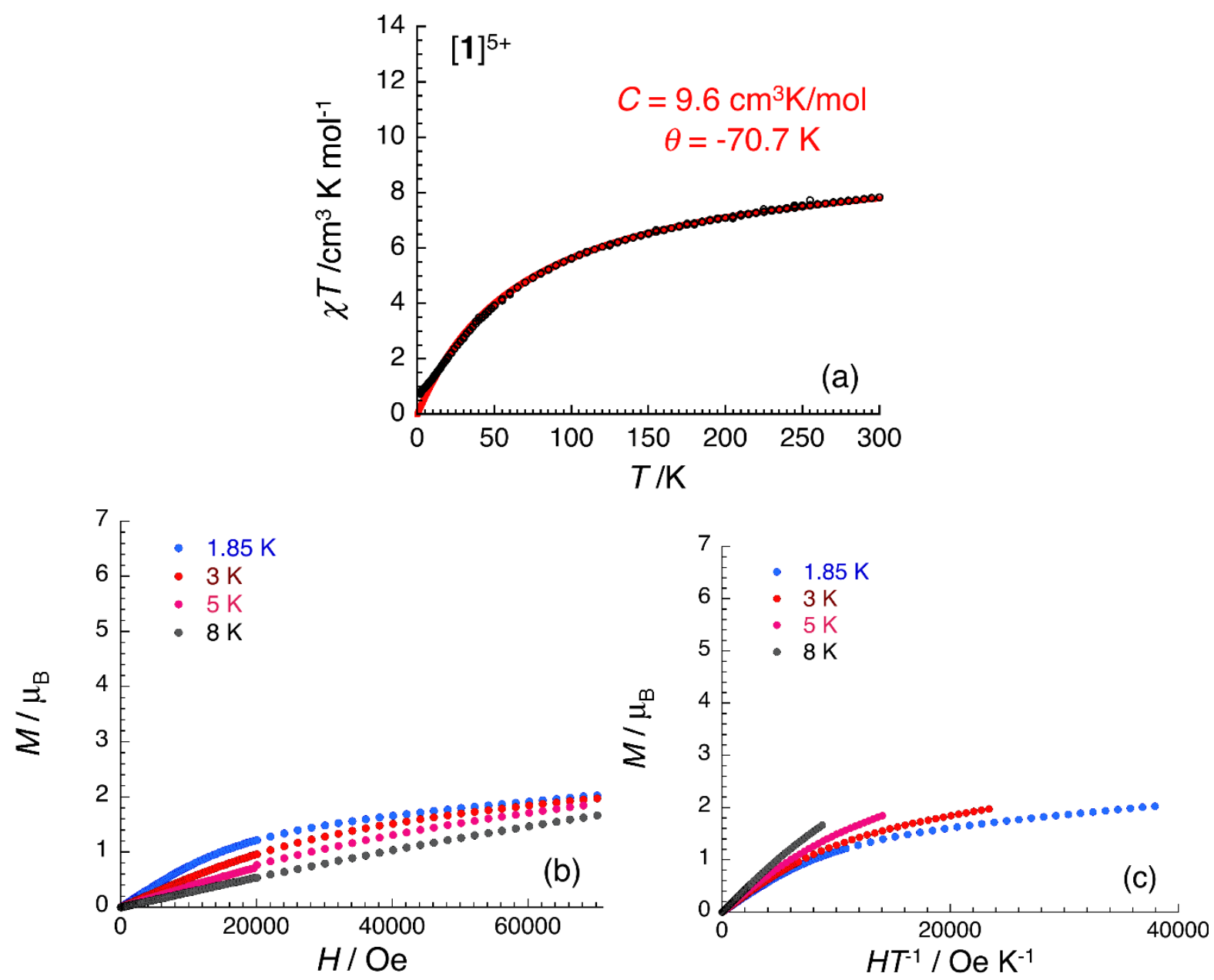

Figure S8. (a) Temperature dependence of the $\chi T$ product (where $\chi$ is the molar magnetic susceptibility that equals $M / H$ per complex) collected in an applied dc magnetic field of $0.1 \mathrm{~T}$ for $1\left(\mathrm{ClO}_{4}\right)_{5}{ }^{\bullet} 6 \mathrm{CH}_{3} \mathrm{CN}$. The solid red line is the best fit of the experimental data to a Curie-Weiss law (see main text). Field dependence of the magnetization, $M$, for $1\left(\mathrm{ClO}_{4}\right)_{5}{ }^{\circ} 6 \mathrm{CH}_{3} \mathrm{CN}$ below $8 \mathrm{~K}$ (scanning at $100-400$ Oe.min ${ }^{1}$ for $H<1 \mathrm{~T}$ and $500-2500$ Oe. $\mathrm{min}^{-1}$ for $H>1 \mathrm{~T}$ ) plotted as (b) $M$ vs $H$ and (c) $M$ vs $H / T$ plots.

\section{References}

1. Romain, S.; Rich, J.; Sens, C.; Stoll, T.; Benet-Buchholz, J.; Llobet, A.; Rodriguez, M.; Romero, I.; Clerac, R.; Mathoniere, C.; Duboc, C.; Deronzier, A.; Collomb, M.-N., Multireversible Redox Processes in Pentanuclear Bis(Triple-Helical) Manganese Complexes Featuring an Oxo-Centered triangular $\left\{\mathrm{Mn}^{\mathrm{II} 2} \mathrm{Mn}^{\mathrm{III}}\left(\mu_{3}-\mathrm{O}\right)\right\}^{5+}$ or $\left\{\mathrm{Mn}^{\mathrm{II}} \mathrm{Mn}^{\mathrm{III}}\left(\mu_{3}-\mathrm{O}\right)\right\}^{6+}$ Core Wrapped by Two $\left\{\mathrm{Mn}^{\mathrm{II} 2}(\mathrm{bpp})_{3}\right\}^{-}$. Inorg. Chem. 2011, 50 (17), 8427-8436.

2. Gouré, E.; Gerey, B.; Clémancey, M.; Pécaut, J.; Molton, F.; Latour, J.-M.; Blondin, G.; Collomb, M.-N., Intramolecular Electron Transfers Thwart Bistability in a Pentanuclear Iron Complex. Inorg. Chem. 2016, 55 (18), 9178-9186. 